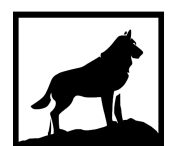

Michigan

Technological

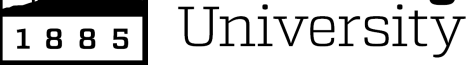

Michigan Technological University

Digital Commons @ Michigan Tech

Dissertations, Master's Theses and Master's Reports

2020

MONITORING MAMMAL COMMUNITY SHIFTS ACROSS

SILVICULTURAL TREATMENTS UTILIZING CAMERA TRAPS AND

THE DEVELOPMENT OF INVERTEBRATE- DERIVED DNA IN

HARDWOOD FORESTS OF NORTH AMERICA

Shallen Gurtler

Michigan Technological University, sagurtle@mtu.edu

Copyright 2020 Shallen Gurtler

Recommended Citation

Gurtler, Shallen, "MONITORING MAMMAL COMMUNITY SHIFTS ACROSS SILVICULTURAL TREATMENTS UTILIZING CAMERA TRAPS AND THE DEVELOPMENT OF INVERTEBRATE- DERIVED DNA IN HARDWOOD FORESTS OF NORTH AMERICA", Open Access Master's Thesis, Michigan Technological University, 2020. https://doi.org/10.37099/mtu.dc.etdr/1095

Follow this and additional works at: https://digitalcommons.mtu.edu/etdr

Part of the Genetics Commons, and the Terrestrial and Aquatic Ecology Commons 


\title{
MONITORING MAMMAL COMMUNITY SHIFTS ACROSS SILVICULTURAL TREATMENTS UTILIZING CAMERA TRAPS AND THE DEVELOPMENT OF INVERTEBRATE- DERIVED DNA IN HARDWOOD FORESTS OF NORTH AMERICA
}

\author{
By \\ Shallen Gurtler

\begin{abstract}
A THESIS
Submitted in partial fulfillment of the requirements for the degree of MASTER OF SCIENCE

In Forest Molecular Genetics and Biotechnology
\end{abstract} \\ MICHIGAN TECHNOLOGICAL UNIVERSITY \\ 2020 \\ (C) 2020 Shallen Gurtler
}


This thesis has been approved in partial fulfillment of the requirements for the Degree of MASTER OF SCIENCE in Forest Molecular Genetics and Biotechnology.

College of Forest Resources and Environmental Science

Thesis Co-Advisor: Carsten Kuelheim

Thesis Co-Advisor: Kristin Brzeski

Committee Member: Yvette Dickinson

College Dean: $\quad$ Andrew Storer 


\section{Table of Contents}

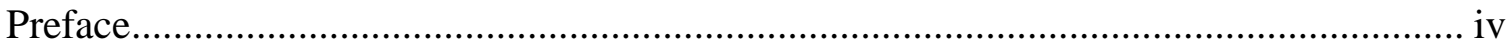

Acknowledgements .......................................................................................................

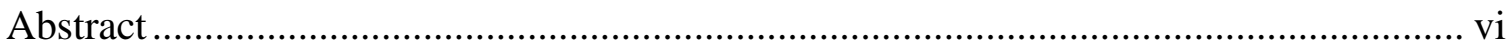

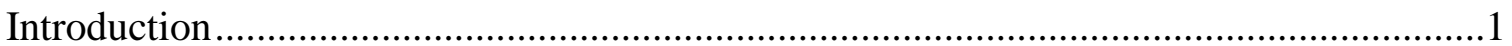

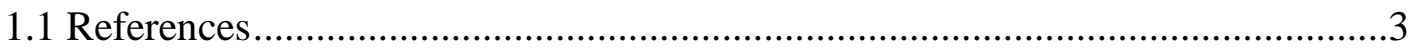

The effect of silviculture treatment on mammal communities in northern hardwood

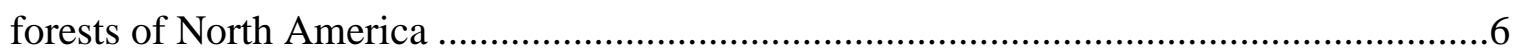

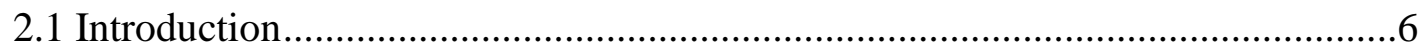

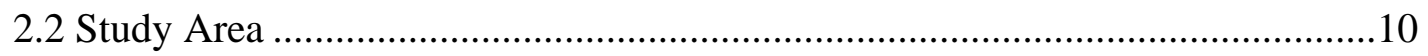

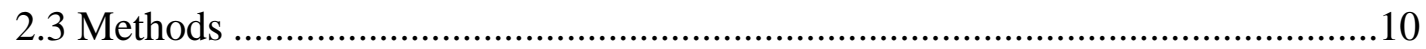

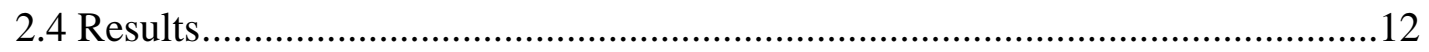

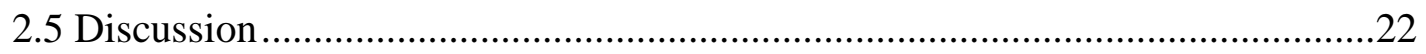

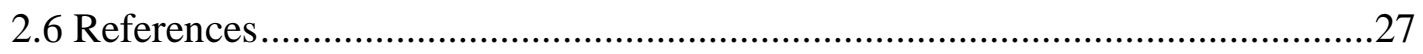

Literature Review: Moving toward iDNA studies in the hardwood forests of North America by utilizing ticks and mosquitoes.....................................................................

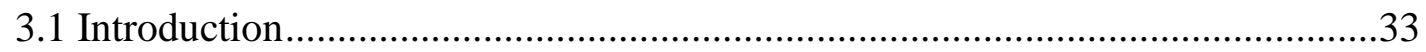

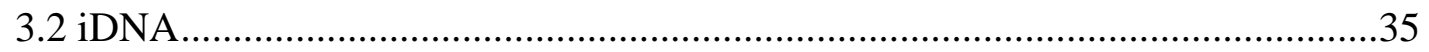

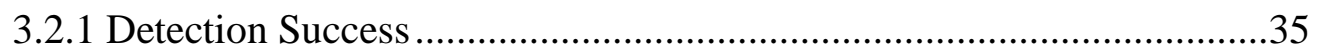

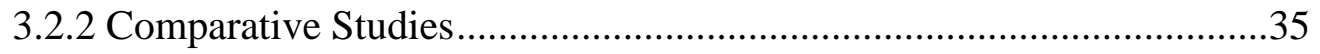

3.2.3 Current Limitations ..............................................................................

3.3 iDNA: Hardwood Forests in the Great Lakes region of North America .............38

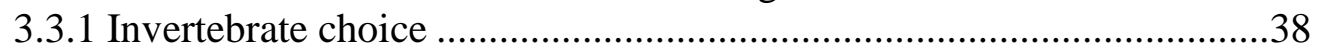

3.3.2 Invertebrate capture ...........................................................................

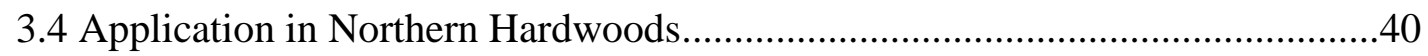

3.5 Next steps: iDNA in Northern Hardwoods ....................................................4

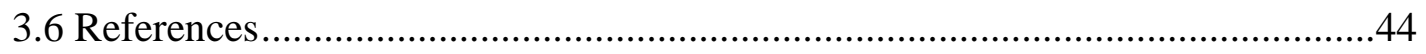

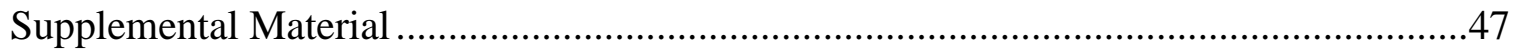




\section{Preface}

This thesis is part of a research project looking at mammal movement across different silviculture treatments as part of the Northern Hardwood - Silvicultural Experiment to Enhance Diversity (NHSEED). The baited camera trap data in Chapter 2 was collected by Dr. Jared Wolfe's 2019 Habitat Ecology class, while I collected the non-baited data The environmental data set utilized in Chapter 3 was collected by Dr. Yvette Dickinson's research team. 


\section{Acknowledgements}

I would like to express my deepest appreciation to my committee who provided me with encouragement, guidance, and patience throughout the duration of this project. I would like to acknowledge the help provided by Dr. Wolfe and his Habitat Ecology class of 2019 for providing pertinent data for this project. I would like to also thank Dr. Yvette Dickinson and her research team for providing ecological data utilized in this thesis. This work is supported by the McIntire-Stennis Program Grant Number 1812067 from the USDA National Institute of Food and Agriculture. Lastly, I gratefully acknowledge Michigan Technological University's Ecosystem Science Center for providing funding for this project. 


\section{Abstract}

Mammal distribution and diversity is quickly changing as humans modify the landscape. In particular, silviculture, which is the practice of controlling the growth, structure, and quality of forests to meet the needs of society and the landowner, influences the habitat usage of mammals. Utilizing camera traps, I monitored shifts in mammal communities across different silviculture treatments in the northern hardwood forests of the Great Lakes region in North America. I assessed the community composition across six canopy treatments and three understory treatments with a total of 2,018 active camera trap nights with 3,321 detections over the course of 147 days. For canopy treatments, high canopy cover shelterwood had the largest positive influence of mammal detection while clearcut showed a negative influence of mammal detection. For understory treatments, artificial tip-up and scarification had higher mammal detection compared to control. Within areas with a history of disturbance it may be beneficial to the mammal communities to include small disturbances, such as those created by silviculture treatments, as local species are likely disturbance-adapted.

Camera traps alone may miss part of the mammal community. To monitor a full community, other techniques need to be considered, such as invertebrate derived DNA (iDNA). iDNA, is emerging as a novel tool which utilizes genomic technologies to monitor and assess mammal communities. Some invertebrates ingest their host's DNA as they feed, which then allows researchers to extract the host's DNA and sequence it. By doing so, the researchers can then create a more complete image of mammal community compositions. This technique has been widely used in tropical zones to monitor mammal community compositions; however, it can be adapted to be used in temperate zones by utilizing ticks and mosquitoes. To adapt this technique, one must understand the environmental influences on invertebrate collection. I investigated the environmental influences on mosquito collection success by running linear regression models. Through running the linear regression models, I found that the canopy cover and time of the month had the largest influence on the collection of female mosquitoes, while tick collection was possibly influenced by the harshness of the winter before. 


\section{Introduction}

Anthropogenic changes are ever occurring across the landscape. Changes, such as road construction and timber harvesting, are leading to landscape fragmentation and destruction of wildlife habitats, which can cause shifts and changes in local mammalian communities. These shifts in the local community can lead to increased transmission of disease, biodiversity loss, and local extirpation or even extinctions (Fahrig, 2003; Bogoni et al., 2016; Spaak et al., 2017). It is important to monitor these shifts and create management plans, to mitigate the likelihood of future community shifts and protect local species. However few tools capture the whole community, so new tools need to be developed to monitor these community shifts. My goal is to understand the effect of forest management on mammalian communities and develop iDNA as a new tool to monitor these mammalian community shifts.

One key anthropogenic factor in forest health is forest management. Forest management, in the form of silviculture, is often used by landowners to manage forest growth overtime for the benefit of society and the landowners (Geenberg, et al., 2015). Disturbance-based forest management is one silvicultural technique that has wide applicability, as this type of forest management mimics local disturbances to minimize the effects of timber harvesting on the local habitats (Mitchell, et al., 2003). There are many different types of silviculture treatments that can use disturbance-based forest management to mimic natural disturbances. For example, clearcutting is the process of removing the canopy in a single harvest and is used to mimic fire and large disturbance events (Leak, 2014). Another treatment used is single tree selection, which is the process of removing specific trees to leave behind most of the canopy (Leak, 2014). This process mimics small windthrow events that naturally occur in a forest (Huppert, et al., 2019). There are other regeneration methods such as shelterwood, which mimic larger windthrow events by removing part of the canopy. In the hardwood forests of the Great Lakes region of North America, it is common to find a mosaic of forest management techniques, each selected based on the needs of the site and the history of the area. However, the most commonly used technique is single tree selection.

Before applying treatments to a site, it is important to understand the effects of these different silviculture treatments on mammalian communities. When choosing management techniques, a forest manager must understand the ecology of the area and how different techniques may help or hinder local fauna. For example, these disturbances may cause a decrease in species that rely on old forests as habitat, such as American martens (Martes americana; Sturtevant et al., 1997). While other species that rely on the disturbances to the forest such as the deer mouse (Peromyscus maniculatus) may increase in population due to the anthropogenic disturbances (Zwolak, 2009). It is important to understand these potential shifts in populations because they can cause shifts within a mammalian community. However, to get a comprehensive view of the communities and any shifts, they need to be monitored for change. There are many ways to monitor mammalian communities such as: transect counts, camera traps, and genetic monitoring. 
One common method to monitor mammalian communities is a transect count. Transect counts are conducted by walking or flying along a transect in a given area and counting mammals as well as signs of mammals (Brack et al. 2018). However, this technique relies strongly on the expertise of the person conducting the transect which means it can be prone to false positives, miscounting, and daytime limitations (Brack et al. 2018, Keeping et al. 2018). The greatest weakness of using transect counts is that it is ultimately subjective and can lead to knowledge gaps of a mammalian community.

Another method of noninvasive mammal monitoring are camera trap studies. These are carried out by utilizing a motion detection camera in the field which can be used to capture the habits of a specific species, monitor rare species, and monitor nocturnal mammals (Roveroa, 2013; Trolliet et al., 2014). The technique can be used for a single species or for mammalian community compositions. However, camera traps have a limited view, which can result in falsely identifying small and arboreal mammals -- or missing them entirely in some cases (Roveroa, 2013; Hobbes and Brehme, 2017). For instance, it is difficult to distinguish a red squirrel (Sciurus vulgaris) and grey squirrel (Sciurus carolinensis) when they run too close to the camera, as the photo will show nothing more than a grey blur. These limitations make it difficult to obtain a full community species list, because while you may obtain objective data it needs context to be properly reviewed.

Noninvasive genetic monitoring is a new way to monitor mammal communities. These studies rely on samples of tissue which can be relatively easy to obtain, but many genetic monitoring studies are limited by their focus on a single species rather than a whole community (Schwartz et al., 2006; Caroll et al., 2018). However, there are other noninvasive genetic monitoring techniques, such as environmentally-derived DNA (eDNA) which takes genetic material from an environmental source such as water (Ruppert et al., 2019). These studies assess community compositions within the environment that the sample comes from. However, this technique is generally done within aquatic systems because the DNA degrades quickly in warm, dry environments.

One subset of eDNA is invertebrate-derived DNA. Invertebrate-derived DNA, or iDNA, is emerging as a novel and cutting-edge tool that utilizes genomic technologies to monitor and assess mammal communities. Invertebrates, such as ticks and mosquitoes, ingest their host's DNA as they feed. The host's DNA can then be extracted and sequenced to discover which mammals the invertebrates fed on. In the tropics, iDNA has been used to monitor mammal diversity (Lee et al. 2015). For iDNA studies, invertebrates are mass captured, the targeted vertebrate DNA is isolated, and then it is sequenced (Hoffmann et al. 2018). The sequenced DNA is matched with known sequences of a specific species from public databases, which provides evidence that the species is present within a site (Rodgers et al. 2017). The technique has been found to be on par with camera traps, with an increased likelihood of monitoring mammals missed by the camera traps (Schnell 2015; Lee et al. 2016). By utilizing iDNA and other techniques in tandem, it is possible to get a comprehensive community 
analysis. These methods can be used to monitor mammal community shifts caused by anthropogenic changes to habitats.

\subsection{References}

Aodha, M.O., Gibb, R., Barlow, K.E., Browning, E., Firman, M., et al. (2018) Bat detective-Deep learning tools for bat acoustic signal detection. PLOS Computational Biology 14(3): e1005995.

Blumstein, D. T., Mennill, D. J., Clemins, P., Girod, L., Yao, K., Patricelli, G., Deppe, J. L., Krakauer, A. H., Clark, C., Cortopassi, K. A., Hanser, S. F., Mccowan, B., Ali, A. M., \& Kirschel, A. N. G. (2011). Acoustic monitoring in terrestrial environments using microphone arrays: Applications, technological considerations and prospectus. Journal of Applied Ecology, 48(3), 758-767. https://doi.org/10.1111/j.1365-2664.2011.01993.x

Bogoni, J. A., Cherem, J. J., Hettwer Giehl, E. L., Oliveira-Santos, L. G., De Castilho, P. V., Picinatto Filho, V., Fantacini, F. M., Tortato, M. A., Luiz, M. R., Rizzaro, R., \& Graipel, M. E. (2016). Landscape features lead to shifts in communities of medium- to large-bodied mammals in subtropical Atlantic Forest. Journal of Mammalogy, 97(3), 713-725. https://doi.org/10.1093/jmammal/gyv215

Brack, K., Oliveira, L.F.B. (2018). Detection errors in wildlife abundance estimates from Unmanned Aerial Systems (UAS) surveys: Synthesis, solutions, and challenges. Methods Ecol Evol. 2018; 9: 1864- 1873.

Carroll, E. L., Bruford, M. W., DeWoody, J. A., Leroy, G., Strand, A., Waits, L., \& Wang, J. (2018). Genetic and genomic monitoring with minimally invasive sampling methods. Evolutionary Applications, 11(7), 1094-1119. https://doi.org/10.1111/eva.12600

Fahrig, L. (2003). Effects of Habitat Fragmentation on Biodiversity. Annual Review of Ecology, Evolution, and Systematics, 34, 487-515. https://doi.org/10.1146/annurev.ecolsys.34.011802.132419

Greenberg, C. H.; Collins, B. S.; McNab, W. H.; Miller, D. K.; Wein, G. R. (2015). Introduction to natural disturbances and historic range of variation: type, frequency, severity, and post-disturbance structure in central hardwood forests. Pages 1-32 $32 \mathrm{p}$.

Hobbs, M. T., \& Brehme, C. S. (2017). An improved camera trap for amphibians, reptiles, small mammals, and large invertebrates. PLoS ONE, 12(10), 1-15. https://doi.org/10.1371/journal.pone.0185026

Hoffmann, C., Merkel, K., Sachse, A., Rodríguez, P., Leendertz, F. H., \& CalvignacSpencer, S. (2018). Blow flies as urban wildlife sensors. Molecular Ecology Resources, 18(3), 502-510. https://doi.org/10.1111/1755-0998.12754 
Hupperts, S. F., Dickinson, Y. L., Webster, C. R., \& Kern, C. C. (2019). Promoting structural and species diversity in Great Lakes northern hardwoods: A conceptual model and its application. Forestry, 92(1), 16-25. https://doi.org/10.1093/forestry/cpy026

Keeping, D., Burger, J. H., Keitsile, A. O., Gielen, M. C., Mudongo, E., Wallgren, M., Skarpe, C., \& Foote, A. L. (2018). Can trackers count free-ranging wildlife as effectively and efficiently as conventional aerial survey and distance sampling? Implications for citizen science in the Kalahari, Botswana. Biological Conservation, 223(March), 156-169. https://doi.org/10.1016/j.biocon.2018.04.027

Leak, W. B., Yamasaki, M., \& Holleran, R. (2014). Silvicultural Guide for Northern Hardwoods in the Northeast. USDA Forest Service General Technical Report NRS-132, April, 46. http://www.fs.fed.us/nrs/pubs/gtr/gtr_nrs132.pdf?

Lee, P. S., Gan, H. M., Clements, G. R., \& Wilson, J. J. (2016). Field calibration of blowfly-derived DNA against traditional methods for assessing mammal diversity in tropical forests 1 . Genome, 59(11), 1008-1022. https://doi.org/10.1139/gen-2015-0193

Lee, P. S., Sing, K. W., \& Wilson, J. J. (2015). Reading mammal diversity from flies: The persistence period of amplifiable mammal mtDNA in blowfly guts (Chrysomya megacephala) and a new DNA mini-barcode target. PLoS ONE, 10(4), 1-12. https://doi.org/10.1371/journal.pone.0123871

Mitchell, R. J., Franklin, J. F., Palik, B. J., Kirkman, L. K., Smith, L. L., \& Hunter, M. L. (1996). Natural Disturbance-Based Silviculture for Restoration and Maintenance of Biological Diversity. National Commission on Science for Sustainable Forestry, 1980, 1-120.

Rodgers, T. W., Xu, C. C. Y., Giacalone, J., Kapheim, K. M., Saltonstall, K., Vargas, M., Yu, D. W., Somervuo, P., McMillan, W. O., \& Jansen, P. A. (2017). Carrion fly-derived DNA metabarcoding is an effective tool for mammal surveys: Evidence from a known tropical mammal community. Molecular Ecology Resources, 17(6), e133-e145. https://doi.org/10.1111/17550998.12701

Royle, J. A. (2018). Modelling sound attenuation in heterogeneous environments for improved bioacoustic sampling of wildlife populations. Methods in Ecology and Evolution, 9(9), 1939-1947. https://doi.org/10.1111/2041-210X.13040

Rovero, F., Martin, E., Rosa, M., Ahumada, J. A., \& Spitale, D. (2014). Estimating species richness and modelling habitat preferences of tropical forest mammals from camera trap data. PLoS ONE, 9(7). https://doi.org/10.1371/journal.pone.0103300 
Ruppert, K. M., Kline, R. J., \& Rahman, M. S. (2019). Past, present, and future perspectives of environmental DNA (eDNA) metabarcoding: A systematic review in methods, monitoring, and applications of global eDNA. Global Ecology and Conservation, 17, e00547. https://doi.org/10.1016/j.gecco.2019.e00547

Schnell, I. B., Sollmann, R., Calvignac-Spencer, S., Siddall, M. E., Yu, D. W., Wilting, A., \& Gilbert, M. T. P. (2015). iDNA from terrestrial haematophagous leeches as a wildlife surveying and monitoring tool - prospects, pitfalls and avenues to be developed. Frontiers in Zoology, 12(1), 1-14. https://doi.org/10.1186/s12983-015-0115-Z

Schwartz, M. K., Luikart, G., \& Waples, R. S. (2007). Genetic monitoring as a promising tool for conservation and management. Trends in Ecology and Evolution, 22(1), 25-33. https://doi.org/10.1016/j.tree.2006.08.009

Sebastián-González, E., Pang-Ching, J., Barbosa, J. M., \& Hart, P. (2015). Bioacoustics for species management: Two case studies with a Hawaiian forest bird. Ecology and Evolution, 5(20), 4696-4705. https://doi.org/10.1002/ece3.1743

Spaak, J. W., Baert, J. M., Baird, D. J., Eisenhauer, N., Maltby, L., Pomati, F., Radchuk, V., Rohr, J. R., Van den Brink, P. J., \& De Laender, F. (2017). Shifts of community composition and population density substantially affect ecosystem function despite invariant richness. Ecology Letters, 20(10), 13151324. https://doi.org/10.1111/ele.12828

Sturtevant, B. R., and J. A. Bissonette. (1997). Stand structure on microtine abundance in Newfoundland: implications for marten. Pages 182-198 in G. Proulx, H. N. Bryant, and P. M. Woodard, eds. Martes: taxonomy, ecology, techniques, and management. Provincial Mus. Alberta, Edmonton.

Trolliet, F., Huynen, M. C., Vermeulen, C., \& Hambuckers, A. (2014). Use of camera traps for wildlife studies. A review. Biotechnology, Agronomy and Society and Environment, 18(3), 446-454.

Wood, C. M., Witham, J. W., \& Hunter, M. L. (2016). Climate-driven range shifts are stochastic processes at a local level: Two flying squirrel species in Maine.

Ecosphere, 7(2), 1-9. https://doi.org/10.1002/ecs2.1240

Zwolak, R. (2009). A meta-analysis of the effects of wildfire, clearcutting, and partial harvest on the abundance of North American small mammals. Forest Ecology and Management, 258(5), 539-545. https://doi.org/10.1016/j.foreco.2009.05.033 


\section{The effect of silviculture treatment on mammal communities in northern hardwood forests of North America}

\subsection{Introduction}

Anthropogenic activity modifies landscapes by altering habitats, causing habitat change and fragmentation. Oftentimes, humans do not consider the faunal impacts of these modifications on resident mammals reliant upon such altered habitats, causing a possible shift of local mammal communities. Such community changes may lead to spread of disease, population declines, and possible local extirpation or even extinction (Fahrig, 2003; Bogoni et al., 2016; Dirzo et al., 2014). To prevent these detrimental changes, researchers should monitor the effects of habitat alterations on local mammalian communities.

Forest management methods such as timber harvesting, are a ubiquitous anthropogenic disturbance to many landscapes around the world. Disturbance-based forest management is commonly implemented in northern hardwood forests of the Great Lakes region in North America, and mimics local natural disturbance patterns through the use of silvicultural treatments. Silviculture is defined as the sustainable management of health, growth, and quality of forests for the needs of society and the landowner (Dey et al., 2012). This management method applies forest canopy and understory treatments to mimic natural disturbances, allowing regeneration of local flora after timber harvest.

Several examples of canopy treatments considered in disturbance-based silviculture are: clearcut, shelterwood, and single-tree selection. Clearcutting removes an entire canopy in a single harvest and mimics large, catastrophic disturbance, allowing for early successional plants to thrive post-harvest (Hupperts et al., 2019). However, clearcut treatments have broad effects on flora, allowing generalist and early successional species to survive. On the other extreme, single-tree selection is the process of removing only predetermined individual trees across the size-classes (Leak et al., 2014). This process mimics small disturbances leaving most of the forest undisturbed and allows it to regenerate. A moderate treatment-type is shelterwood, which is the removal of a canopy across multiple harvests to ensure a specified percentage of canopy remains (Leak et al., 2014). This process can be executed in both high or low canopy coverage in shelterwood sites. Both high- and low-canopy cover sites create unique sheltering effects on early successional plants, which moderates the effects such as extreme high and low temperatures, high light levels, strong winds, and high vapor pressure deficit experienced within clearcut treatments (Yamasaki et al., 2014).

While silviculture treatments mainly focus on the canopy treatments, understory treatments, which also mimic natural disturbances, may aid in regeneration. For example, artificial tip-up is a contemporary process of felling trees, creating a tip-up mound, mimicking the results of natural windthrow (Kern et al., 2019). Another type of 
ground treatment is scarification. Scarification is the process of disturbing the ground by upturning the soil, altering the seedbed by reducing the forest floor litter depth, exposing mineral soil, and mixing organic and mineral soil (Johnsson et al., 2013). These processes create microsites, encourage seedling germination and establishment, and allow for regeneration by mimicking natural disturbances to local flora.

Canopy and understory treatments influence not only stand regeneration but mammalian community compositions as well by altering habitats for mammals (Brown et al., 2020; Nolet et al., 2017). Understanding movement of mammals throughout the Great Lakes region is important because changes in mammalian communities have the capability to influence tree regeneration, extinction rates, and overall mammalian community shifts (Rooney and Waller, 2002; Lavoie et al., 2019). Unfortunately, little research has focused on altered mammal communities within northern hardwood silviculture treatments.

Timber harvesting influences different species by inserting disturbance events within different habitats. Disturbance events, from timber harvest to settlements, exist across the northern hardwood forests of North America (Hupperts et al., 2019). Due to historic disturbances, remaining mammalian species have begun adapting to changes caused by timber harvesting (Greenberg et al., 2015). More specifically the microhabitat used by these species can be altered by the timber harvesting disturbances. Microhabitats are small areas that differ from the surrounding macrohabitat (Rosenzweig and Winakur, 1969; Jorgensen, 2004). Mammals utilize microhabitats differently, which often change the composition of a mammalian community.

Specifically, some small mammals have been shown to benefit from microhabitat disturbances. For example, it has been shown that small mammal populations in Ontario, Canada, another region with high disturbance events, are not influenced by the disturbances caused by timber harvesting (Brown et al., 2020). However, some small mammal species, such as deer mice (Peromyscus maniculatus), have been shown to increase in population after a disturbance event (Zwolak, 2009). Other small mammals have also been shown to benefit from microhabitat disturbances (Jorgenson, 2004; Kaminski et al., 2007). These species have adapted to the changes in habitat caused by timber harvesting.

Mesopredators are mammals that are middle trophic level predators and many of these species have adapted to anthropogenic disturbances such as the red fox (Vulpes vulpes) and racoon (Procyon lotor). These species are widespread generalists. For example, the red fox has shown to adapt to human facilitated disturbances by changing their home range size to cover more territory (Walter et al. 2018; Walton et al., 2017). In Australia, human based disturbances are aiding in the population growth of the invasive red fox (Hradsky et al., 2017). Other species, such as the racoon, preferentially use areas with anthropogenic disturbances when food is available (Beasley et al., 2007). For example, racoons are more likely to den in residential areas (Newbury and Nelson, 2007; Gross 
et al., 2012). These species of mesopredators have adapted to the human disturbances on the landscape.

Interestingly, some mesopredators are more sensitive to anthropogenic disturbances such as the American marten (Martes americana) and fisher (Martes pennanti). Both these species are of economic importance due to fur trapping throughout their range, and the importance of trapping has led to the reintroduction of American martens into Hardwood forests of Michigan (Gehring, et al., 2019). However, these species are more sensitive to forest management (Lavoie et al., 2019; Moriarty et al., 2016). Particularly, the American marten has shown to have a negative relationship with timber harvested disturbance sites (Sturtevant et al., 1997), which is due to the American marten's reliance on late successional and closed canopy forest types (Zielinski et al., 2001; Cheveau et al., 2013). Fishers, like American martens, rely on old growth forests and an abundance of small mammals in the region for food (Suffice et al., 2017). Due to the increase of timber harvesting, the amount of suitable habitat for the American marten and fishers pushed them to use in lower quality habitats or even change the way they use microhabitats (Lavoie et al., 2019). This leads to competition between fishers and American martens. However, fisher populations outcompete American marten populations for resources and occasionally fishers even predate on American martens (Suffice et al., 2017). This makes it imperative to monitor these community shifts to create management plans that protect species like the American marten and fisher.

Another species of management concern is the white-tailed deer (Odocoileus virginianus), which are an important, economically valuable species. White-tailed deer are an economical species through hunting and hunting has contributed \$336 million for wildlife management in 2009 in the United States (Hewitt, 2015). This revenue is important for supporting wildlife management. However, white-tailed deer also influence silviculture treatment sites by altering forest regeneration through browsing (Tilghman et al., 1989; Russell et al., 2017;). White-tailed deer have been shown to prefer early successional plants such as American beech (Fagus grandifolia; Horsley et al., 2003), which has altered the growth and survival of American beech in areas with high white-tailed deer densities. This grazing influences the growth of different plant species making it more difficult for the survival of these species in areas with high density of white-tailed deer. Understanding the microhabitat usage of white-tailed deer in silviculture treatment sites can lead to better forest and wildlife management policies.

The goal of my study is to better understand mammalian community composition and their changes across different silvicultural treatments in northern hardwood (maplebeech-birch) forests of the Great Lakes region of North America. The results of this study may be applicable across hardwood forest treatments on mammal communities world-wide. My study has three major objectives: 1) to document mammalian community composition in the NHSEED sites, 2) to understand the effects of microhabitats, created by canopy treatments, on mammal detection rates, and 3) to understand the effects of microhabitats, created by understory treatments, on mammal detection rates. 


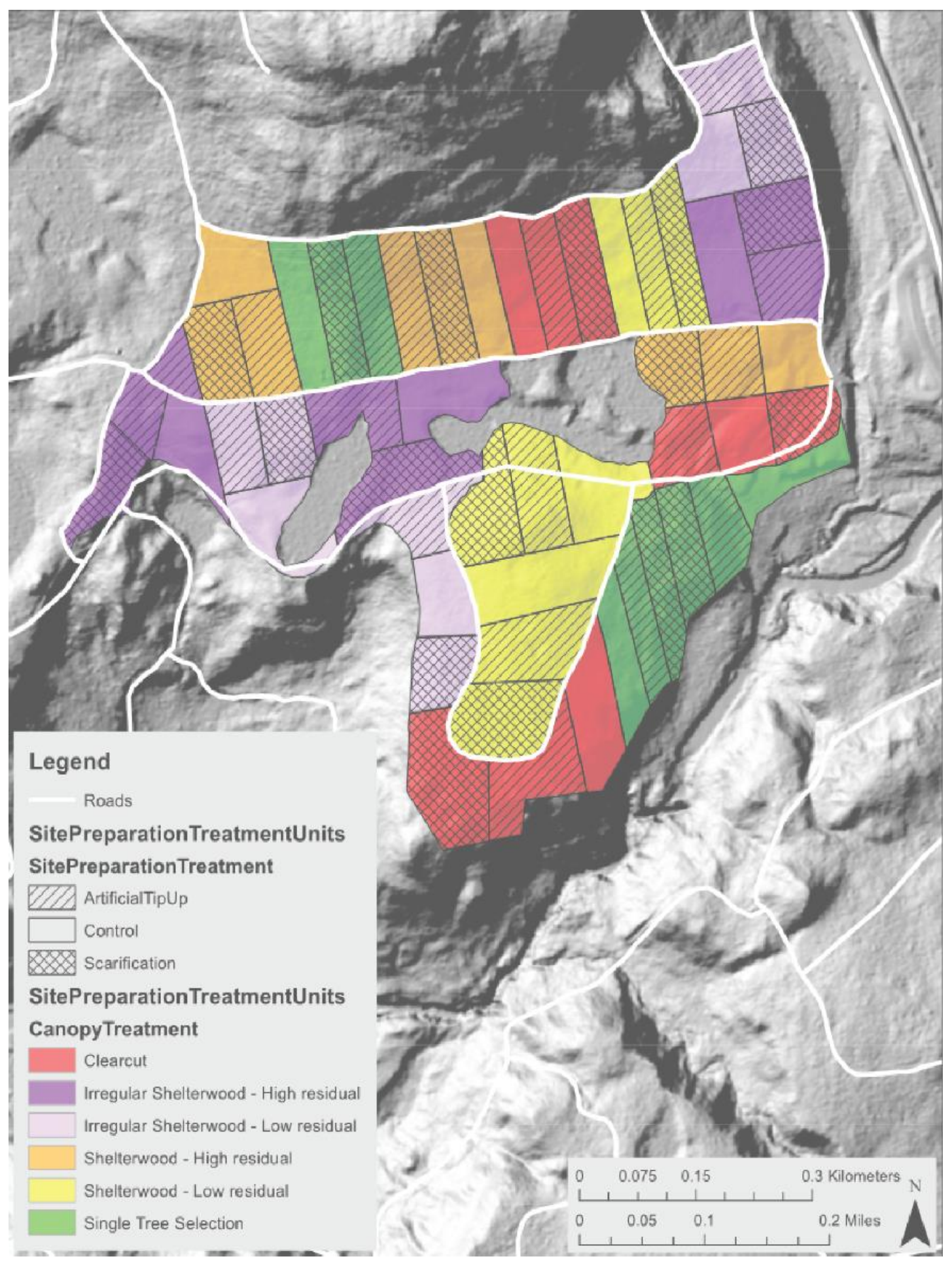

Figure 2.1. Silvicultural Experiment for Enhancing Diversity (NHSEED) plots located in Baraga county, Michigan. These plots had 6 canopy treatments and 3 understory treatments for a total of 18 different treatments. 


\subsection{Study Area}

To accomplish my research goals, I studied mammal communities in Baraga County, of Michigan's Upper Peninsula. My study region was located near Lake Superior, the largest of the United States' Great Lakes. The region was in a temperate zone, with an average of $708 \mathrm{~mm}$ of precipitation each year and heavy snow coverage during winter (NOAA, 2018). Monthly average temperatures ranged from $24.3^{\circ} \mathrm{C}$ (July) to $-13^{\circ} \mathrm{C}$ (January) (NOAA, 2018). This study was conducted from the months of June to November 2019, in an experimental hardwood forest designed to test silvicultural treatments (Figure 2.1).

Silviculture treatment sites were part of a research study, the Northern Hardwood Silvicultural Experiment to Enhance Diversity (NHSEED), to understand regrowth of local hardwood forests after various harvest regimes. At NHSEED, there were three understory treatments and six canopy treatments for a total of eighteen combined treatment-types. Understory treatments were control, scarification, and artificial tip-up, while canopy treatments were clearcut, high canopy cover irregular shelterwood, low canopy cover irregular shelterwood, high canopy cover shelterwood, low canopy cover shelterwood, and single-tree selection. Each of the combined treatments were done in triplicate, giving a total of 54 silviculture sites. Plots were approximately two acres each. These plots were considered smaller than the home ranges of several of the large mammals in my study region ( $\geq 3 \mathrm{~kg})$; however, I was interested in the microhabitat use of these plots.

\subsection{Methods}

To assess the mammal communities across various treatment-types, I used data from two different camera trap studies. The first study was an unbaited camera trap study that took place from June 04, 2019 through October 19, 2019. The second study was a baited camera trap study that was conducted as part of a class project from September 05, 2019 through October 24, 2019 to monitor flying squirrel populations.

For the unbaited camera trap study, I deployed Bushnell Trophy cameras for three cycles during the field season. Each cycle consisted of 18 camera traps, rotated approximately every 38 nights to cover each silviculture forest treatment-type. Here, nights were defined as the 24 hour period that the cameras are out for. Camera locations for each cycle were randomly chosen for the 18 camera traps using the 54 plots. Each camera was placed near the center of the plot and directed north to prevent false triggering by the sun. For the duration of the study, the following settings were used: photo size of $8 \mathrm{M}$, capture number of three, interval between photos one second, and TV out PAL.

The baited camera trap study, conducted by Dr. Jared Wolfe's Habitat Ecology Course in Fall 2019, also utilized Bushnell Trophy cameras. There were five camera cycles during the field season and each cycle included 10 camera traps, rotated approximately 
every seven nights to cover each silviculture treatment-type. Each camera was placed 10 feet away from a baited tree, snag, or deer exclosure. Bait consisted of a mixture of molasses, oats, bacon fat, and peanut butter.

I used CamTrapR to sort, identify, and organize camera data (Niedballa et al., 2016). First, I downloaded the raw images into a raw image folder before copying them into a second folder for processing. These images were corrected with a time shift, when the dates were incorrect in the metadata, by utilizing the function timeShiftImages from the CamTrapR package (Niedballa et al., 2016). After timeshifting the photos to the correct dates, I appended the dates on to the file name of each photo. Finally, I sorted the pictures by species into folders: false detection, unidentified animal, unidentified small mammal, unidentified squirrel, human, turkey, warbler, white-crowned sparrow, American marten, black bear, least chipmunk, eastern chipmunk, unidentified chipmunk, white-tailed deer, unidentified flying squirrel, gray squirrel, gray wolf, unidentified mouse, snowshoe hare, racoon, American red squirrel, and southern redbacked vole. Once sorted, the species name was appended to the photos.

To investigate the species detections, I created a species detection list of all the species detected with the function recordTable, where a detection only counted if there was a thirty minute gap from the previous detection of the same species at the same camera (Niedballa et al., 2016). To focus on natural mammal communities, I removed human detections, false triggers, unidentified animal, unidentified small mammal, unidentified squirrel, unidentified chipmunk, and non-mammals for downstream analysis. I used MatLab to calculate the detection rate of each species at each site, which was calculated as the number of detections divided by working trap nights. To compare detection rates of species across treatment-types, I plotted the detection rates in MatLab.

To look at the number of species possible to detect and show whether the study was conducted for a long enough duration to capture the full mammalian community, I used species accumulation analysis. This analysis allows the comparison of the diversity in each plot. To look at the species accumulation in the plots across the NHSEED, and different treatments, I used EstimateS version 9.1 (Colwell et al., 2013). I extrapolated the species accumulation to 200 days to see if there were more species to detect with a longer study. The species accumulation curves were plotted in MatLab.

To visualize the distribution of mammals across treatments, I used a Principal Components Analysis (PCA). PCA showed the grouping and distribution of different mammals in the different sites. I utilized two groupings, the first was all the understory treatments and the second was all canopy treatments. Using the detection rate at each given site, I ran prcomp with R Studio (RStudio Team, 2015) and plotted the results on a bivariate plot. To look at the influence of rare detections (species detected only once) on the PCA analysis, I ran it both with and without rare species.

Lastly, I investigated the effect of treatment-type on the detection rate of all mammals and white-tailed deer utilizing a mixed model. I modeled the effect of canopy and 
understory treatments on the detection rate of mammals and the detection rate of whitetailed deer, including a random effect of camera traps baited or unbaited. For this analysis, I used a tweedie family distribution in the glmmTMB R package (Brooks et al., 2017). I used the tweedie family of error distributions to account for a meanvariance relationship, allowing for the over dispersion and zero padding seen in the data (Dunn and Smyth, 2005; Brown et al., 2020). I assessed model fit by plotting the residuals to look at the spread. Utilizing a null model to compare each model in the $\mathrm{R}$ package MuMIn (Barton, 2009), I ranked the models based on their corrected Akaike's Information Criterion (AICc) and AICc model weight (AICc wi). The best model was chosen based on a difference of delta 2 AICc.

Throughout data analyses, I combined irregular and regular shelterwood into shelterwood, because at the time of my data collection, irregular was the same as regular shelterwood (personal comm. Dr. Yvette Dickinson, May 1, 2020). For the first harvest irregular and regular shelterwood are harvested similarly. However, for the second harvest the irregular shelterwood and regular shelterwoods will be harvested differently. This study was conducted after the first harvest but before the second. Due to this the irregular and regular shelterwood systems are the same at the scale of this study. A second grouping was small mammals and large mammals, broadly based on size. I did this grouping for a better understanding of mammal movement through microhabitats caused by silviculture treatments since smaller mammals are influenced by microhabitats differently than larger mammals. In the small mammal group there were the following species/groups of species: least chipmunk (Neotamias minimus), eastern chipmunk (Tamias striatus), flying squirrel (Glaucomys spp.), gray squirrel (Sciurus carolinensis), mouse (Peromyscus spp.), snowshoe hare (Lepus americanus), red squirrel (Sciurus vulgaris), and southern red-backed vole (Myodes gapperi). In the large mammal group there were the following species: black bear (Ursus americanus), white-tailed deer (Odocoileus virginianus), gray wolf (Canis lupus), American marten (Martes americana), and racoon (Procyon lotor). Mesopredators, such as the American marten, were grouped with large mammals despite being smaller than $3 \mathrm{~kg}$.

\subsection{Results}

To look at the mammalian community across silviculture treatments, there were 2,018 active camera trap nights with 3,321 detections over the course of 147 nights (Supplemental Table 1). For canopy treatments, the working trap nights were as follows: clearcut had 344 nights, low density shelterwood had 659 nights, high density shelterwood had 746 nights, and single tree selection had 269 nights (Supplemental Table 2). For understory treatments the working trap nights were as follows: control had 524 nights, scarification had 772 nights, and artificial tip-up had 722 nights (Supplemental Table 3). The following groups were detected across the NHSEED: turkey, unidentified warbler, white-crowned sparrow, American marten, black bear, chipmunk, white-tailed deer, flying squirrel, gray squirrel, gray wolf, unidentified mouse, snowshoe hare, racoon, red squirrel, and southern red-backed vole 
(Supplemental Table 4) . To focus on mammalian communities, birds were removed from further analysis (Table 2.1).

Table 2.1. The number of detections per mammal species from a combined baited and unbaited camera trap study in the Northern Hardwood Silvicultural Experiment to Enhance Diversity (NHSEED) plots located in Baraga county, Michigan from June 04, 2019 through October 24, 2019.

\begin{tabular}{|c|c|c|}
\hline Common Name & Scientific Name & Count of Species \\
\hline American Marten & Martes americana & 3 \\
\hline Black Bear & Ursus americanus & 8 \\
\hline Eastern Chipmunk & Tamias striatus & 64 \\
\hline Flying Squirrel & Pteromyini spp. & 2 \\
\hline Gray Squirrel & Sciurus carolinensis & 1 \\
\hline Gray Wolf & Canis lupus & 1 \\
\hline Least Chipmunk & Neotamias minimus & 177 \\
\hline Racoon & Procyon lotor & 9 \\
\hline Red Squirrel & Tamiasciurus hudsonicus & 11 \\
\hline Snowshoe Hare & Lepus americanus & 1 \\
\hline Southern Red-Backed Vole & Myodes gapperi & 12 \\
\hline Unidentified Mouse & & 27 \\
\hline White-Tailed Deer & Odocoileus virginianus & 379 \\
\hline
\end{tabular}

To examine communities across NHSEED, I plotted the detection rate of each mammal. Of the mammals detected, white-tailed deer had the highest detection rate (0.11 detections per night), while least chipmunks had the second highest detection rate (0.09 detections per night). Mice were detected at a rate of 0.008 detections per night, while the lowest detection rates were gray wolf, snowshoe hare, and gray squirrel (0.0003 detections per night, Figure 2). 


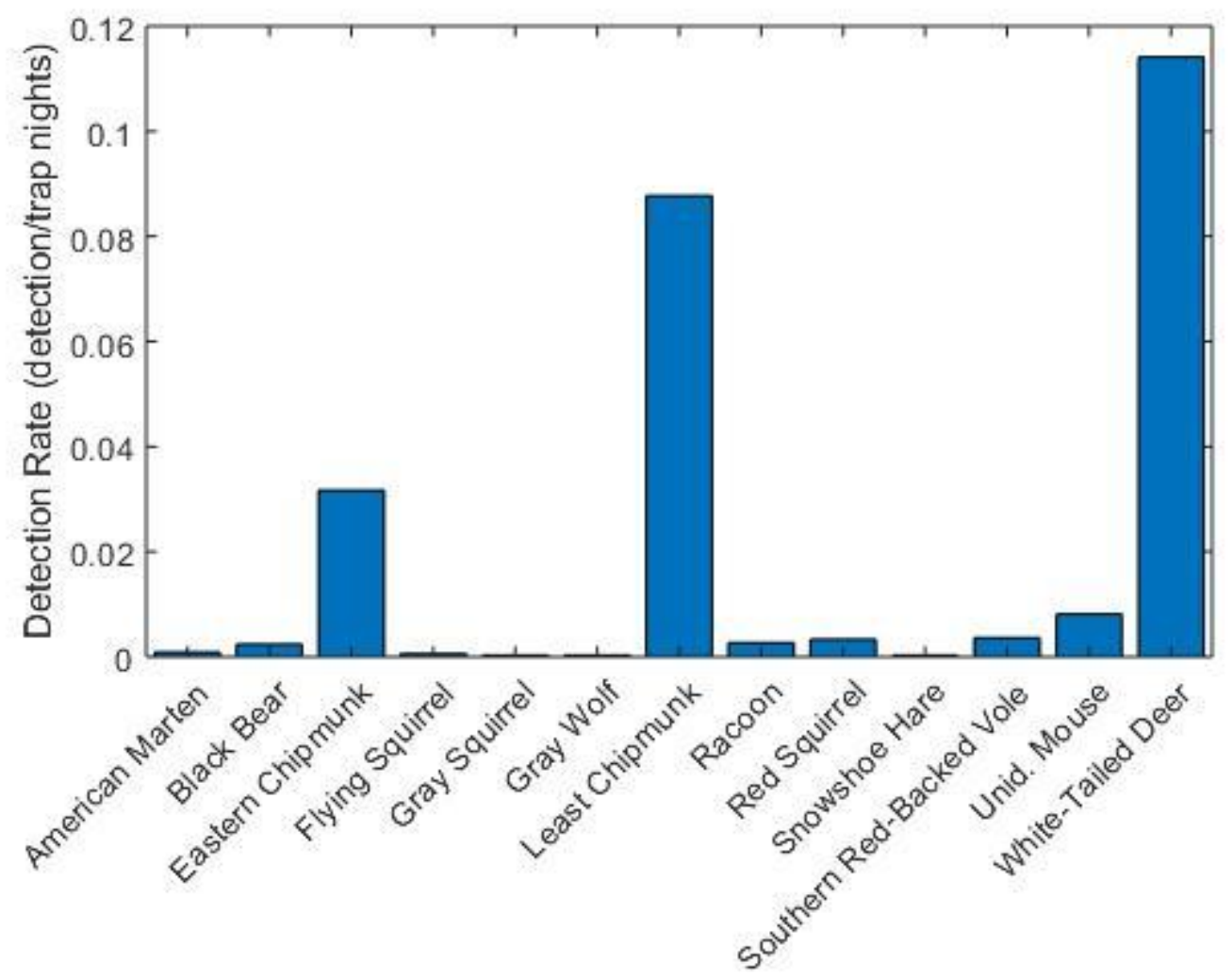

Figure 2. Detection rate of different species across the entire Northern Hardwood Silvicultural Experiment to Enhance Diversity (NHSEED). This was part of a combined baited and unbaited data collection through a camera trap study in Baraga county, Michigan from June 04, 2019 through October 24, 2019.

Amongst canopy treatments, high density shelterwood had the most detected species with eight identified species, while clearcut had the least detected species with three identified species. High canopy cover shelterwood had the highest small mammal detection rate. White-tailed deer detection rates were greatest in the shelterwood treatments (low shelterwood: 0.04 detections per night, high shelterwood: 0.039 detections per night), while white-tailed deer detection was lowest in single tree selection (0.01 detections per night). Least chipmunk detection was highest in the single tree selection sites $(0.11$ detections per night) and lowest in the clearcut $(0.007$ detections per night, Figure 3). 


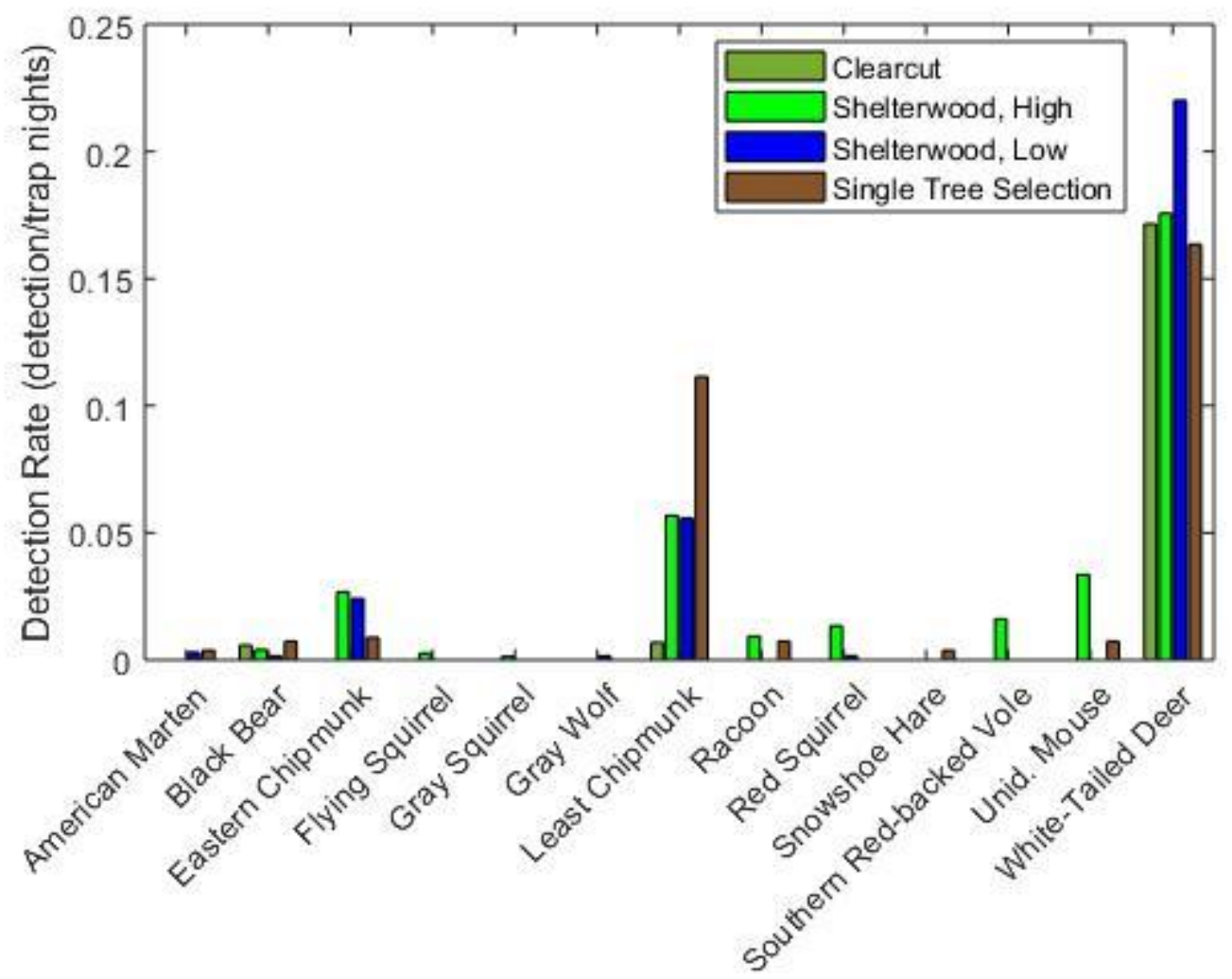

Figure 3. Detection rate of mammalian species in different silviculture canopy treatments. The canopy treatments tested were clearcut, high canopy cover shelterwood, low canopy cover shelterwood, and single tree selection. This was part of a combined baited and unbaited camera trap study located in the Northern Hardwood Silvicultural Experiment to Enhance Diversity (NHSEED) plots located in Baraga county, Michigan from June 04, 2019 through October 24, 2019.

Amid understory treatments, artificial tip-up plots had the most detected species at 11 species. Control plots had nine different species detected and scarification had seven different species detected, while artificial tip-up had more small mammals detected. White-tailed deer detections were highest in scarification ( 0.21 detections per night) and lowest in control ( 0.04 detections per night). Least chipmunk detection was highest in control ( 0.10 detections per night, Figure 4). 


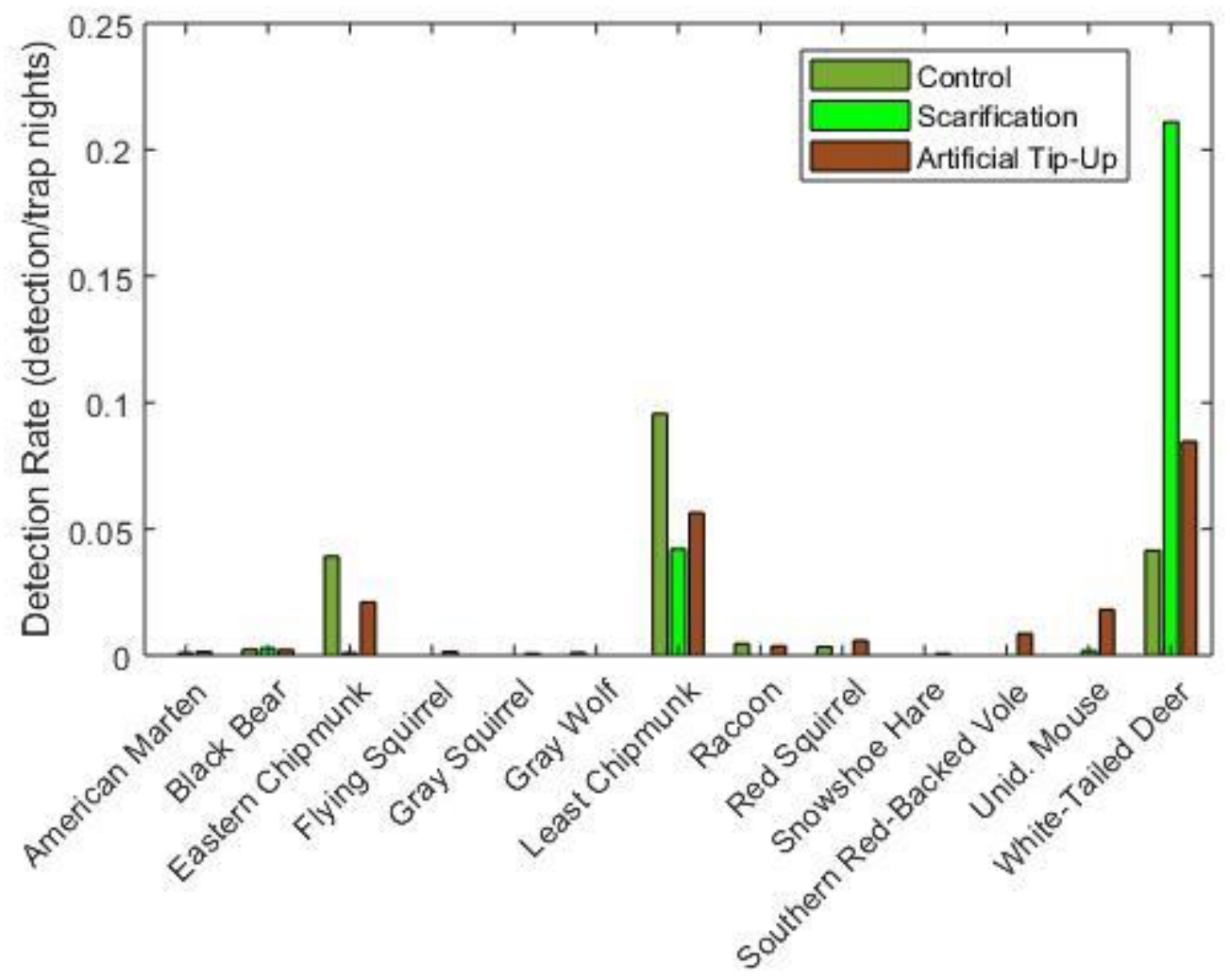

Figure 2.4. Detection rate of mammalian species in different silviculture understory treatments. The understory treatments tested were control, scarification and artificial tip-up. This was part of a camera trap study done in the Northern Hardwood Silvicultural Experiment to Enhance Diversity (NHSEED) plots located in Baraga county, Michigan from June 04, 2019 through October 24, 2019.

Species accumulation was the estimation of possible detections across a study area. The species accumulation across the entire NHSEED study area was 14 species (95\% CI: 9.94, 17.85); at which species accumulation began to plateau, but was still increasing, suggesting more mammals could be detected with a longer camera trap study (Figure 2.5). Clearcut showed the lowest species accumulation at 3 species (95\% CI: 3,3), while high density shelterwood showed the highest species at 9 species $(95 \%$ CI: 11.34, 9.99). Although high density shelterwood had the highest species accumulation, low density shelterwood (7 species, 95\% CI: 3.76, 10.24) and single tree selection (8 species, $95 \%$ CI: 8,8) were comparable to each other (Figure 2.6). For understory treatments, artificial tip-ups had the highest species accumulation at 12 species (95\% CI: 10.12 13.88), while control had the lowest at 6 species (95\% CI: 5.04, 6.96; Figure 2.7). 


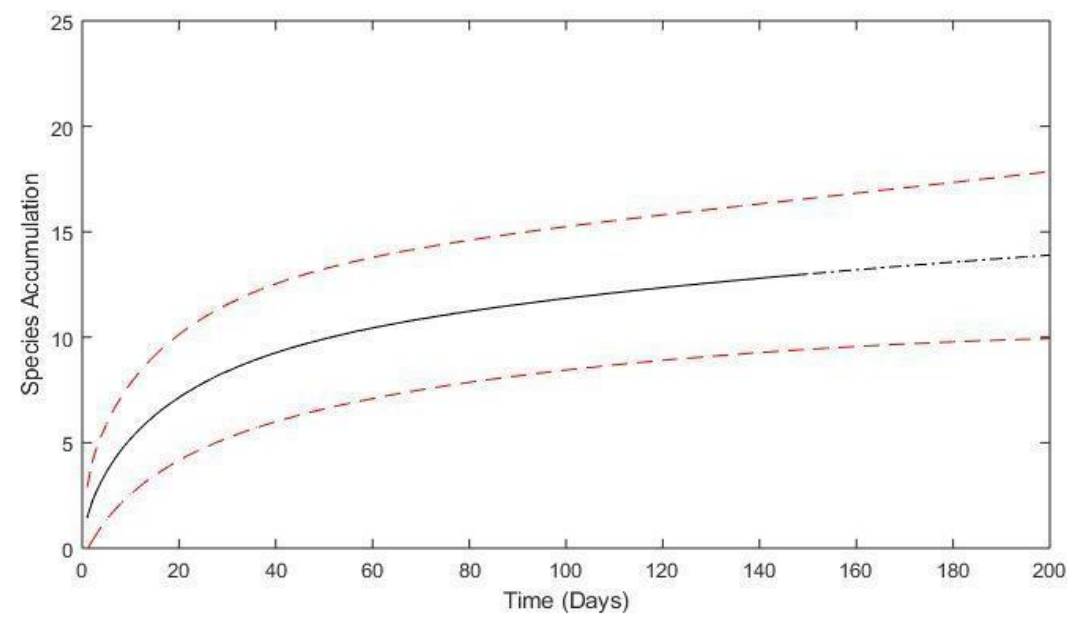

Figure 2.5. The species accumulation of the northern hardwood forests silviculture treatments in Baraga county, Michigan from June 04, 2019 through October 24, 2019 as part of Northern Hardwood Silvicultural Experiment to Enhance Diversity (NHSEED) project.
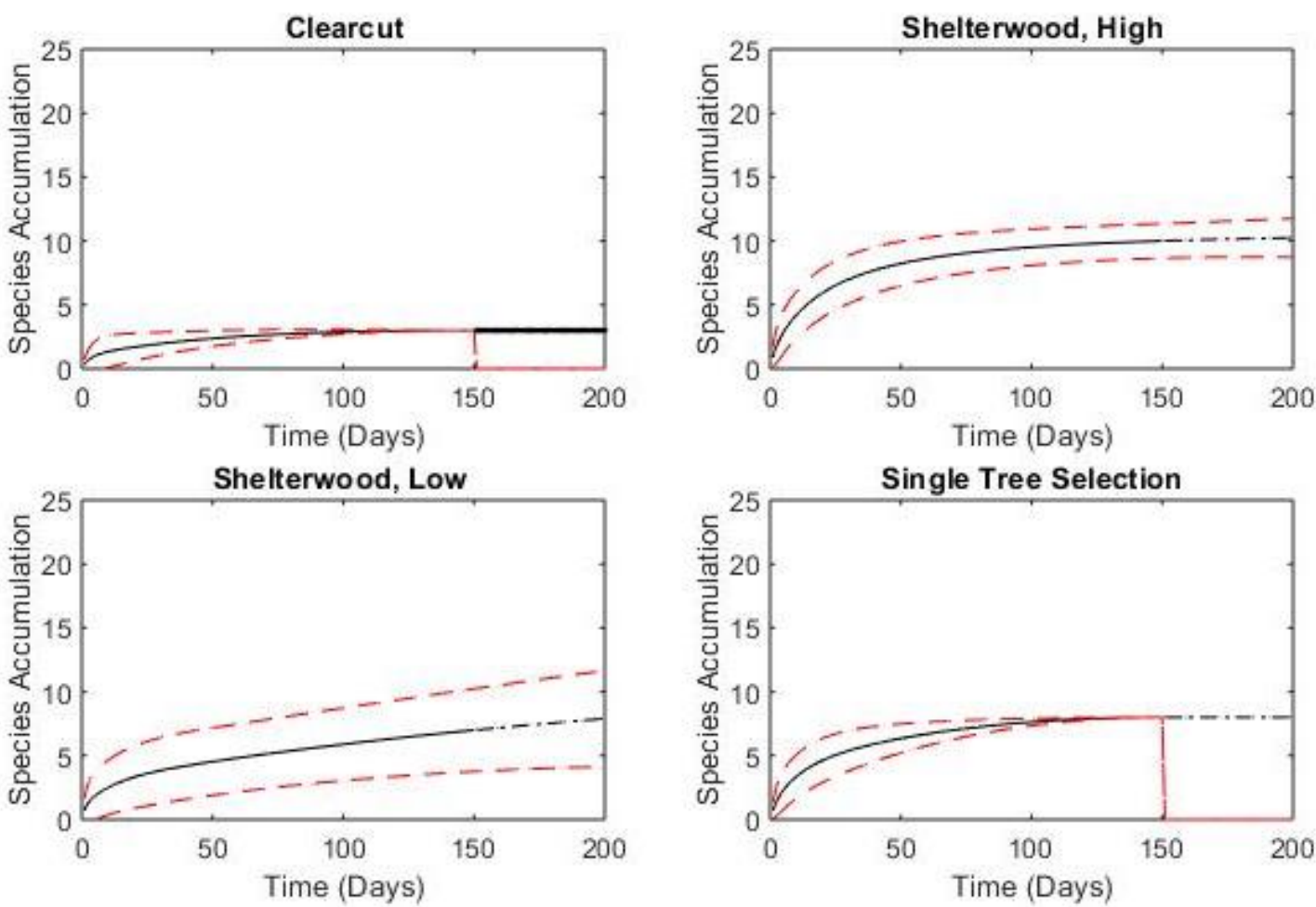

Figure 2.6. The species accumulation of four different canopy treatments. The canopy treatments tested were clearcut, high canopy cover shelterwood, low canopy cover shelterwood, and single tree selection. This was part of a camera trap study done across the Northern Hardwood Silvicultural Experiment to Enhance Diversity (NHSEED) plots located in Baraga county, Michigan from June 04, 2019 through October 24, 2019. 

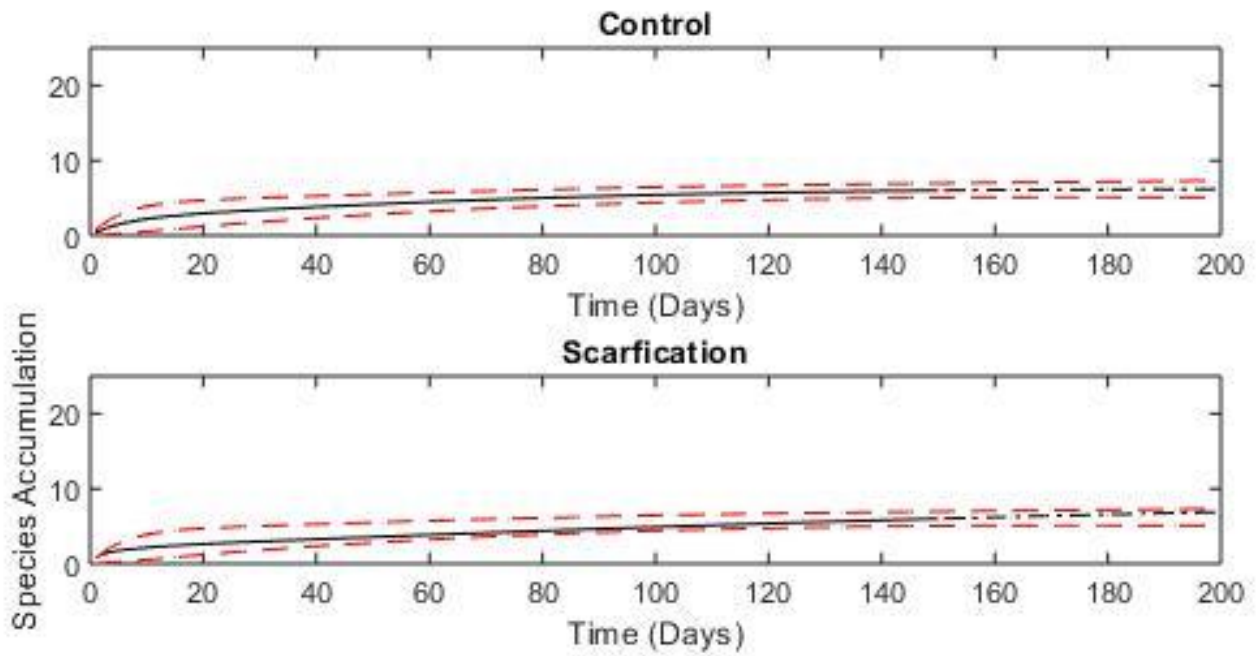

Artificial Tip Up

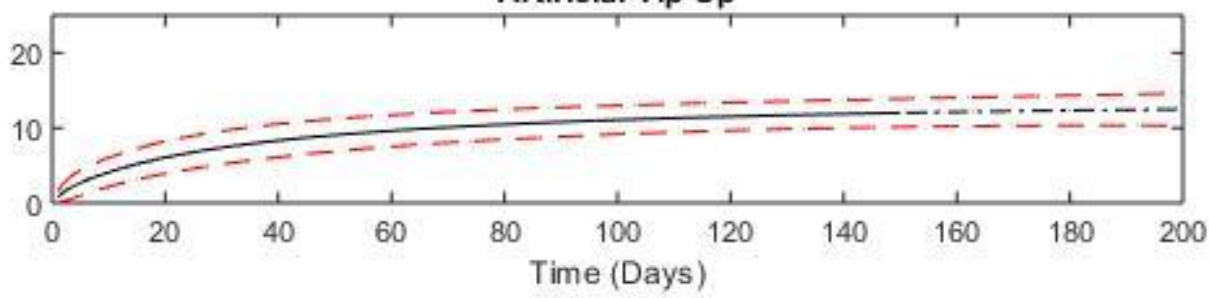

Figure 2.7. The species accumulation of three different understory treatments across the Northern Hardwood Silvicultural Experiment to Enhance Diversity (NHSEED) plots located in Baraga county, Michigan from June 04, 2019 through October 24, 2019. The understory treatments tested were control, scarification and artificial tip-up.

From the principal component analysis were that small mammals were more likely to be found in high canopy cover shelterwood, while larger mammals were more likely to be found in single tree selection. However, mammals of both sizes were less likely to be detected in clearcut plots (Figure 2.8). This trend was still evident with the removal of rare species, or species with a single detection (Supplemental Figure 1) With the exception of least chipmunks and eastern chipmunks, small mammals were found more often in tip-up sites, while large mammals were found more often in scarification sites (Figure 2.9). After removing rare species detections, the trend of small mammals in artificial tip-up was still present (Supplemental Figure 2). 


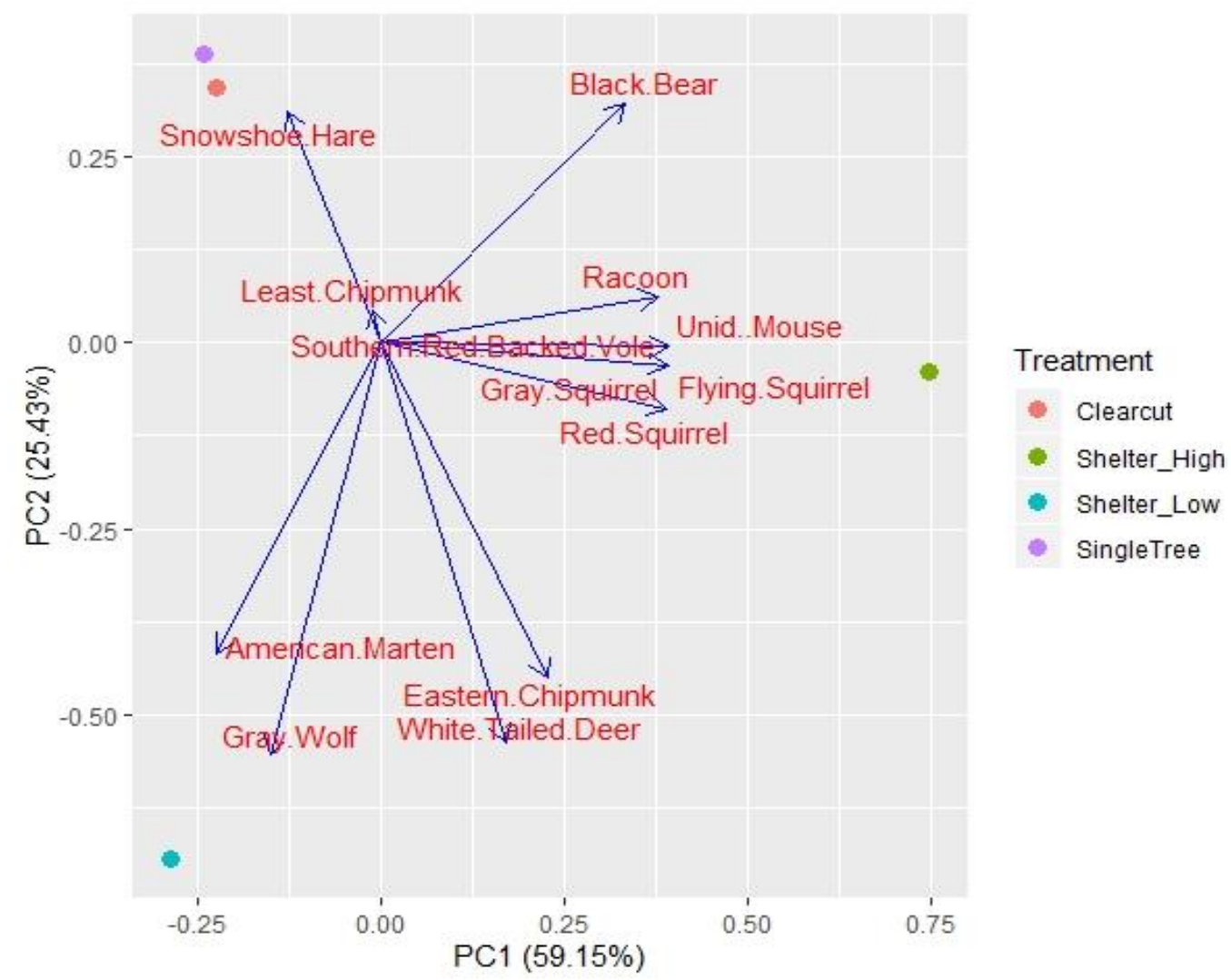

Figure 2.8. Principal components analysis of the community composition of four different canopy treatments in the Northern Hardwood Silvicultural Experiment to Enhance Diversity (NHSEED) plots located in Baraga county, Michigan from June 04, 2019 through October 24, 2019. 


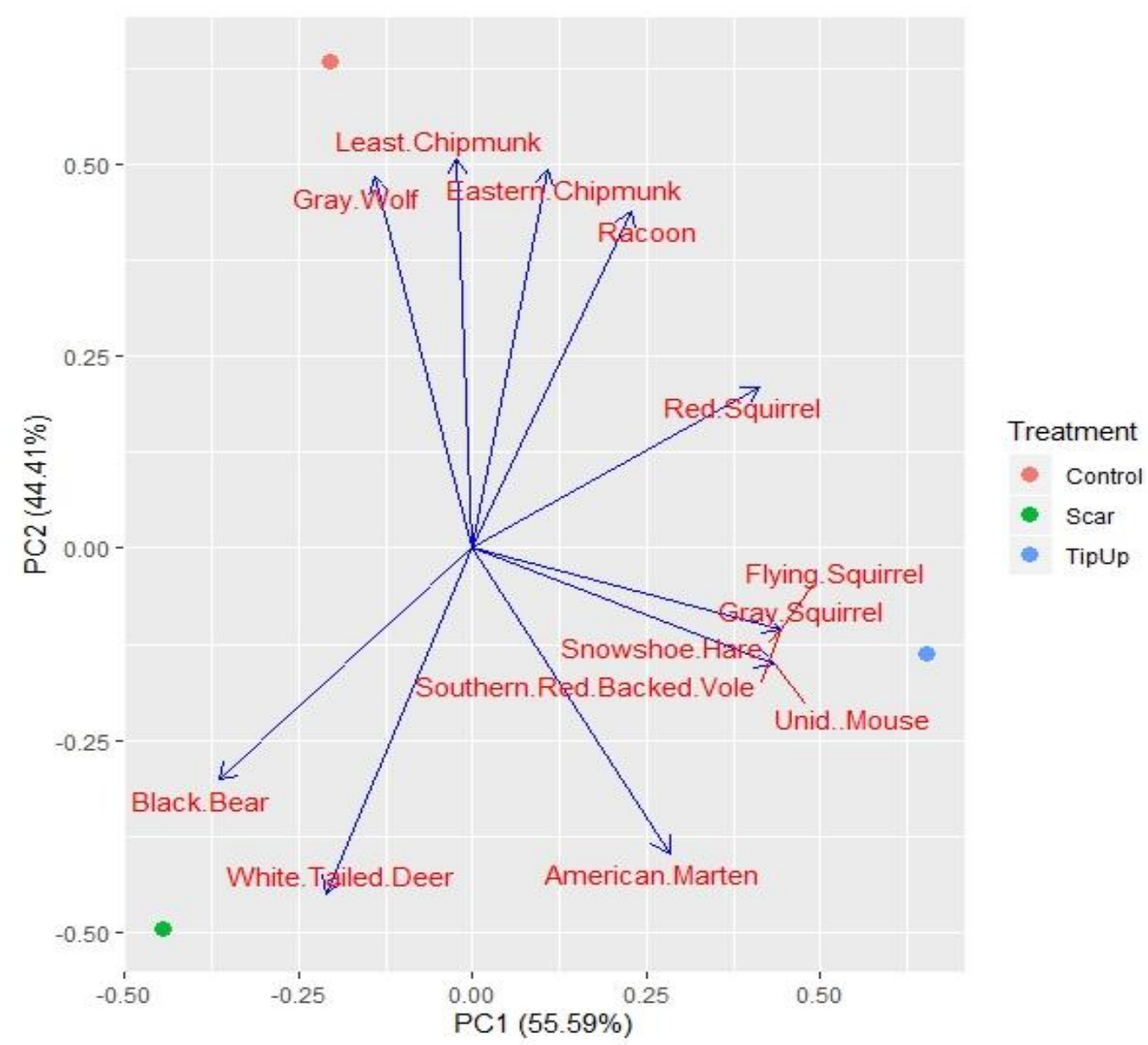

Figure 2.9. Principal components analysis of the community composition of three different understory treatments in the Northern Hardwood Silvicultural Experiment to Enhance Diversity (NHSEED) plots located in Baraga county, Michigan from June 04, 2019 through October 24, 2019.

Modeling the effects on mammal detection rate, I looked at the effect of canopy and understory on overall mammal detection. Canopy treatment played a role in mammal detection rates with a delta Corrected Akaike Information Criterion of 6.63 when compared to understory treatments (Table 2.2). Clearcut had a negative relationship on overall mammal detection ( $\beta=-1.65,95 \% \mathrm{CI}=-2.61,-0.69)$, while both low density and high density shelterwood had a positive relationship on overall mammal detection $(\beta=0.83,95 \% \mathrm{CI}=0.03,1.64 ; \beta=0.87,95 \% \mathrm{CI}=0.06,1.67)$. Single tree detection had confident intervals that crossed zero suggesting there was no effect on mammal detection $(\beta=0.59,95 \% \mathrm{CI}=-0.38,1.56$; Table 2.3$)$. 
Table 2.2. The model rankings for the effect of silviculture treatment on mammal detection rate. The top model ( Canopy) was picked by utilizing the delta Corrected Akaike Information Criterion ( $\triangle \mathrm{AICc}$ ) with a difference of $\geq 2$. This shows the canopy affected the detection rate of mammals as the best model. Degrees of freedom were shown as df. The Corrected Akaike Information Criterion weight was shown as AICc wi. The model with the highest weight was the best fit model.

\begin{tabular}{|l|c|c|c|c|c|c|}
\hline \multicolumn{1}{|c|}{ Model } & Intercept & Canopy & Understory & df & $\Delta$ AICc & AICc $w i$ \\
\hline$\sim$ Canopy & + & + & & 7 & 0.00 & 0.66 \\
\hline$\sim$ Understory & + & & + & 6 & 2.40 & 0.20 \\
\hline Null & + & & & 3 & 4.45 & 0.07 \\
\hline$\sim$ Canopy+Understory & + & + & + & 9 & 4.61 & 0.07 \\
\hline
\end{tabular}

Table 2.3. The top model (Table 2.2: C Canopy) for the effect of silvicultural treatments on mammal detection rate. Clearcuts had a negative effect, while high and low canopy cover shelterwoods had a positive effect. The coefficient was shown as $\beta$, standard error was shown as SE, and the $95 \%$ confidence intervals were shown as 95\% CL.

\begin{tabular}{c|l|c|c|c|}
\hline $\begin{array}{c}\text { Dependent } \\
\text { Variable }\end{array}$ & $\begin{array}{l}\text { Explanatory } \\
\text { Variable }\end{array}$ & $\beta$ & SE & $95 \%$ CL \\
\hline \multirow{2}{*}{$\begin{array}{c}\text { Mammal } \\
\text { Detection } \\
\text { Rate }\end{array}$} & Slearcut & -1.65 & 0.49 & $-2.61,-0.69$ \\
& Shelterwood High & 0.87 & 0.41 & $0.06,1.67$ \\
& Single Tree Selection & 0.59 & 0.50 & $-0.38,1.56$ \\
\hline
\end{tabular}

Modeling the influence of treatment on white-tailed deer detection, the effect of canopy treatment had the best model (Table 2.4). The control treatment had a negative relationship with white tailed deer detection $(\beta=-2.39,95 \% \mathrm{CI}=-2.97,-1.79)$, while scarification had a positive relationship $(\beta=1.15,95 \% \mathrm{CI}=0.44,1.86)$. Artificial tip-up $95 \%$ confidence interval crossed zero suggesting a zero relationship with white-tailed deer detection $(\beta=0.27,95 \% \mathrm{CI}=-0.51,1.06$; Table 2.5$)$. 
Table 2.4. Model rating for the effect of silviculture treatments on white-tailed deer detection rate. The top model showed the understory affecting the detection rate of white-tailed deer. Delta Corrected Akaike Information Criterion ( $\triangle \mathrm{AICc}$ ) was used to identify the best model. Degrees of freedom were shown as df. The Corrected Akaike Information Criterion weight was shown as AICc wi. The model with the highest weight was the best fit model.

\begin{tabular}{|l|c|c|c|c|c|c|}
\hline \multicolumn{1}{|c}{ Model } & Intercept & Understory & Canopy & df & $\Delta$ AICc & AICc $w i$ \\
\hline$\sim$ Understory & + & + & & 6 & 0.00 & 0.94 \\
\hline$\sim$ Canopy+Understory & + & + & + & 9 & 6.63 & 0.03 \\
\hline Null & + & & & 4 & 7.66 & 0.02 \\
\hline$\sim$ Canopy & + & & + & 7 & 13.79 & 0.00 \\
\hline
\end{tabular}

Table 2.5. The top model (Table 2.4: Understory) for the effect of silvicultural treatments on white-tailed deer detection. Control had a negative effect on white-tailed deer detection, while scarification had a positive effect on white-tailed deer detection. The coefficient was shown as $\beta$, standard error was shown as SE, and the $95 \%$ confidence intervals were shown as $95 \% \mathrm{CL}$.

\begin{tabular}{|c|c|c|c|c|}
\hline $\begin{array}{l}\text { Dependent } \\
\text { Variable }\end{array}$ & $\begin{array}{l}\text { Explanatory } \\
\text { Variable }\end{array}$ & $\beta$ & SE & $95 \% \mathrm{CL}$ \\
\hline \multirow{3}{*}{$\begin{array}{c}\text { Deer } \\
\text { Detection } \\
\text { Rate }\end{array}$} & Control & -2.39 & 0.30 & $-2.97,-1.79$ \\
\hline & Scarification & 1.15 & 0.36 & $0.44,1.86$ \\
\hline & TipUp & 0.27 & 0.40 & $-0.51,1.06$ \\
\hline
\end{tabular}

\subsection{Discussion}

This study investigated the effect of different silvicultural treatments on mammal community compositions in northern hardwood (maple-beech-birch) forests of the Great Lakes region of North America. These forests are home to many species of management concern, such as white-tailed deer, gray wolves, and culturally important furbearers like American marten; however timber harvesting may be influencing these populations. I found that different silviculture treatments had varied effects on the communities of mammals; canopy treatments had the most influence on overall mammal detection while clearcut had a negative influence and shelterwood had a positive influence. Conversely, white-tailed deer were more strongly influenced by understory treatments with control showing the least effect. Both canopy and understory played a role in mammalian density and community compositions.

One of the goals of the project was to document what species were found in the Northern Hardwood Silvicultural Experiment to Enhance Diversity (NHSEED) sites, which were sites that were part of a study to monitor changes in flora and fauna communities due to silviculture treatments. However, some groups of mammals detected could not be identified down to species. The small mammals detected in these sites were the least chipmunk (Neotamias minimus), eastern chipmunk (Tamias striatus), flying squirrel (Glaucomys spp.), gray squirrel (Sciurus carolinensis), unidentified mouse, snowshoe hare (Lepus americanus), red squirrel (Sciurus vulgaris), 
and southern red-backed vole (Myodes gapperi). The large mammals detected were black bear (Ursus americanus), white-tailed deer (Odocoileus virginianus), gray wolf (Canis lupus), American marten (Martes americana), and racoon (Procyon lotor). These species were commonly found in hardwood forests of North America (Kurta, 2017). However, I did not detect some common species known to be in the region such as gray fox (Urocyon cinereoargenteus), red fox (Vulpes vulpes), coyotes (Canis latrans), or fisher (Martes pennanti; Kurta, 2017). With a longer study, it is possible that I could detect more species missed by this study (Figure 2.5).

The second goal of this project was to understand the effect of canopy treatments on the detection of mammals. Cameras were placed across four silviculture treatments types: clearcut, single tree selection, low canopy cover shelterwood, and high canopy cover shelterwood. Of these, clearcut showed the lowest species accumulation and had a negative relationship with mammal detection, while high canopy cover shelterwood showed the highest species accumulation and a positive relationship with mammal detection (Figure 2.6 and Table 2.3).

Clearcut treatments were created by removing the canopy in a single harvest and were found to have a negative effect on mammal detection. However, clearcut sites have shown a positive effect on small mammals in boreal and temperate forests of Europe (Bogdziewicz and Zwolak, 2014). This difference between Europe and the plots in this study was most likely due to the lack of habitat for the specific mammal species detected. Clearcuts were considered early successional habitats which were ideal for species such as striped field mouse (Apodemus agrarius; Leak, 2014; Zwolak, 2009). These species thrived on the abundant vegetation cover and increased seed mast created by a clearcut event (Jenson et al., 2017; Zwolak, 2009). However, in contrast to Zwolak (2009), at NHSEED there was a negative correlation of mammal detection (Figure 2.3). This difference may be due to the need of mammals of the Great Lakes region. These mammals rely on more canopy cover than the clearcut sites can offer, leaving the area prone to harsh conditions and creating a hostile environment. This suggests that clearcutting was not an ideal silviculture treatment for preserving the wildlife populations in northern hardwood forests.

Single tree selection is the process of harvesting only pre-determined trees, leaving the majority of the canopy with minimal disturbance and, unexpectedly, little effect on the mammal community composition. Because single tree selection leaves mature trees for production of the seed mast, it was expected that there would be a higher mammalian detection in single tree selection plots since the highest amount of natural habitat is retained (Tinya et al., 2019). Instead, there was no relationship with the detection rate of mammal species observed in this study (Table 2.3). This was most likely due to the species found in the region being more adapted to natural disturbances created in a forest (Greenberg et al., 2015). Specifically, disturbance-based wildlife in this region relied on natural disturbances that are mimicked with different timber harvest techniques, such as with a shelterwood harvest. 
However, not all species detected were wildlife adapted to disturbance regimes. For example, the American marten is known to be sensitive to forest disturbances (Moriarty et al., 2016), which makes them more susceptible to changes in habitat. It was not surprising that the American marten was detected in the single tree selection, because single tree selection offers more canopy cover and the least amount of disturbance (Miller 1994). Another mesopredator, racoons, were also detected in single tree selection. Racoons have been known to prefer hardwood forests over other forest types, but timber harvesting has been shown to affect the daytime resting choices of these mesopredators (Kirby, 2015). However, both these species were also detected in low canopy cover shelterwood.

Shelterwood harvesting is when the canopy is removed over the course of multiple harvests, leaving a single-aged stand, which allows for protection from harsh conditions while offering trees as habitat for aboral species (Degraff et al. 2006). It was found that both shelterwood low canopy cover and high canopy cover had a positive relationship with mammalian detection rates (Table 2.3). This may be due to the high microsite heterogeneity offered by a shelterwood system (Hupperts et al., 2019). These microsites offer a wider range of habitats for small mammals and increased food availability because of the treatment preparation. For example, in a spruce forest, southern redbacked vole populations increased in shelterwood sites compared to untreated sites, because there was an increase of forage sites, thus, increasing insect and seed availability (Von Trebra et al., 1998). By increasing foraging sites, small mammal populations can increase more rapidly. Shelterwood sites also offer more tree gaps and soft seed mast that is preferred by species like the eastern chipmunk (Tamias striatus; Kellner et al., 2019; Holloway and Malcolm, 2010). The increase in food availability and heterogeneity of the sites could have increased the density of small mammals in shelterwood sites.

Overall, shelterwood treatments increased the detection rate of small mammal species, allowing for a possibility that mesopredators will frequent these sites as well (Hollway and Malcolm, 2010; Leblond et al., 2013). This is based on studies that have found that an increase of small mammals and mast in an area has led to an increase of American marten and fisher populations (Jenson et al., 2012). American martens are more likely to frequent poor microhabitats for hunting while living in macrohabitats surrounding these sites; for example, in coniferous boreal forests of eastern Canada martens preferred mixed forests that had little to no disturbance, but were still detected in poor habitat sites (Cheveau et al., 2013). Similarly, this study could be detecting the effect of martens living in the preferred habitat, while hunting in poorer microhabitats.

Other mesopredators such as the fisher, red fox, or coyote were not detected in the NHSEED sites. This may be due to habitat restrictions and apex predators in the region. For example, fishers relied on mature forests and foxes were found in more open areas (Thompson, 1988; Sturtevant et al., 1996). Due to the specific treatments focused on in this study, these mesopredators could have been missed. Another possibility is the presence of predators such as the black bear and gray wolf, may have decreased the 
mesopredator activity through killing or inducing fear (Ritchie and Johnson, 2009). For example, coyote populations have shown a negative correlation with an increase of gray wolf populations, whereas more gray wolves in a region correlated with fewer coyotes are within that region (Berger and Conner, 2008). Similarly, the results of this study may be observing the effect of apex predators excluding mesopredators from these microhabitats.

White-tailed deer are an overabundant species that strongly impact forest regeneration and were detected across all canopy treatments (Figure 2.3). Disturbances to the hardwood forests caused an increase in food availability for white-tailed deer (Lashley et al., 2011). For example, in upland hardwood forests white-tailed deer preferentially browsed sites with disturbances due to an increase of forge availability (Lashley et al.,2011). White-tailed deer browsing can alter the growth of different species of woody plants (Brousseau et al., 2009; Beguin et al., 2009) and other techniques such as deer exclosure may mitigate the effect of white-tailed deer browse. However, overall whitetailed deer densities are high throughout the region (Rawinski 2008; Patton et al., 2018), and this may just be a reflection of the high density of white-tailed deer always present at NHSEED.

The third goal of this project was to understand the effect of understory treatments on the detection of mammals. Three understory treatments were studied: control, artificial tip-up, and scarification. Of these, artificial tip-ups had the highest species accumulation and control had the lowest species accumulation (Figure 2.7). These treatments influenced white-tailed deer microhabitat usage as well. Scarification had a positive effect, while control had a negative effect on white-tailed deer detection (Table 2.5).

Artificial tip-up had the highest species richness compared to other understory treatments, which could be due to the increased downed wood (Kern et al., 2019). Downed wood offered an increase of habitat heterogeneity and food sources for small mammals (Manning and Edge, 2004). For example, in Australia, there was an increase in small mammal populations with increased heterogeneity of habitats available (Stirnemann et al., 2015). Also, Kellner et al. (2014) found that small mammal densities increased in downed wood regions, because the small mammals utilized the downed wood as microhabitats. Franklin, et al (2002) found this same trend of an increase in small mammal density in artificial tip-up sites, where the mounds could provide new habitats and overwintering sites for small mammals. The increase in heterogeneity of the habitat may have increased the small mammal population present on my study plots.

The presence of mesopredators in artificial tip-up was most likely due to the increase of small mammals and an increase of nesting sites. Mesopredators can be influenced by food availability; for example, the American marten is known to change habitat usage in response to prey movement (Jenson et al., 2012; Gosse et al., 2005). The increase of small mammals in the sites may have drawn in the mesopredators detected: racoons and 
American martens. However, the presence of mesopredators in artificial tip-up may be due to the increased resting and denning sites. It has been found that American marten use downed trees as resting and denning sites (Bull and Heater, 2000). Raccoons have also shown to prefer forest habitat, when available, for nesting by utilizing downed wood and tree cavities (Henner et al., 2004; Newbury and Nelson, 2007). It was possible the downed trees offer denning for the mesopredators present at NHSEED.

White-tailed deer detection was highest in scarification sites. Scarification upturns the soil, allowing for an increased germination of different plant species (Degraff et al. 2006), which allows for more plant species to be available for habitat and grazing (Johansson et al., 2012). White-tailed deer are more likely to forage in areas with increased shrubs and forbs (Masse and Cote, 2009), which is more present in scarification sites compared to control sites (Zaczek et al., 1997). Artificial tip-up may offer the same increase of forging sites, but have increased obstacles for white-tailed deer and protection for the plants (Keeton et al., 2006; Kern et al., 2019). Due to this there were less white-tailed deer in artificial tip-up sites compared to scarification. However, both sites show an increase of white-tailed deer density compared to control sites.

This study found that silvicultural treatments influenced the mammal communities present within the different plots. Clearcut treatments reduced the number of mammals detected, while high canopy cover shelterwood increased mammal densities. Both scarification and artificial tip-up understory treatments had higher densities of mammals compared to control sites. This suggests that a high canopy cover shelterwood with an understory treatment of either scarification or artificial tip-up would be more effective in maintaining diverse mammal communities in a disturbancebased system similar to the species in northern hardwood (maple-beech-birch) forests of the Great Lakes region of North America. Ideally, a long-term study would be conducted to discover the environmental influences on mammalian community movements across silvicultural treatments and may provide more insight into seasonal movement and movement of communities over time. 


\subsection{References}

Barton, K. (2009) Mu-MIn: Multi-model inference. R Package Version 0.12.2/r18. http://R-Forge.R-project.org/projects/mumin/

Beasley, J. C., Devault, T. L., Retamosa, M. I., \& Rhodes, O. E. (2007). A Hierarchical Analysis of Habitat Selection by Raccoons in Northern Indiana. Journal of Wildlife Management, 71(4), 1125-1133. https://doi.org/10.2193/2006-228

Beguin, J., Pothier, D., \& Prévost, M. (2009). Can the impact of deer browsing on tree regeneration be mitigated by shelterwood cutting and strip clearcutting? Forest Ecology and Management, 257(1), 38-45. https://doi.org/10.1016/j.foreco.2008.08.013

Berger, K.M. and Conner, M.M. (2016). Recolonizing Wolves and Mesopredator Suppression of Coyotes : Impacts on Pronghorn Population Dynamics. Wiley Stable, 18(3), 599-612.

Bogdziewicz, M., \& Zwolak, R. (2014). Responses of small mammals to clear-cutting in temperate and boreal forests of Europe: A meta-analysis and review. European Journal of Forest Research, 133(1), 1-11. https://doi.org/10.1007/s10342-013-0726-X

Bogoni, J. A., Cherem, J. J., Hettwer Giehl, E. L., Oliveira-Santos, L. G., De Castilho, P. V., Picinatto Filho, V., Fantacini, F. M., Tortato, M. A., Luiz, M. R., Rizzaro, R., \& Graipel, M. E. (2016). Landscape features lead to shifts in communities of medium- to large-bodied mammals in subtropical Atlantic Forest. Journal of Mammalogy, 97(3), 713-725. https://doi.org/10.1093/jmammal/gyv215

Brooks, M.E., Kristensen K., van Benthem, K.J., Magnusson, A., Berg, C.W., Nielsen, A., Skaug, H.J., Maechler, M., \& Bolker, B.M. (2017). "glmmTMB Balances Speed and Flexibility Among Packages for Zero-inflated Generalized Linear Mixed Modeling." The R Journal, 9(2), 378-400.

Brousseau, M., Thiffault, N., Beguin, J., Roy, V., \& Tremblay, J. P. (2017). Deer browsing outweighs the effects of site preparation and mechanical release on balsam fir seedlings performance: Implications to forest management. Forest Ecology and Management, 405(May), 360-366. https://doi.org/10.1016/j.foreco.2017.09.024

Brown, G. S., Pollock, L., DeWitt, P. D., \& Dawson, N. (2020). Responses of terrestrial animals to forest characteristics and climate reveals ecological indicators for sustaining wildlife in managed forests. Forest Ecology and Management, 459(October 2019), 117854. https://doi.org/10.1016/i.foreco.2019.117854

Bull, E.L. and T.W. Heater. 2000. Resting and denning sites of American martens in northeastern Oregon. Northwest Science 74:179-185.

Campbell, T. A., Laseter, B. R., Ford, W. M., Odom, R. H., \& Miller, K. V. (2006). Abiotic factors influencing deer browsing in West Virginia. Northern Journal of Applied Forestry, 23(1), 20-26. https://doi.org/10.1093/njaf/23.1.20

Cheveau, M., Imbeau, L., Drapeau, P., \& Belanger, L. (2013). Marten space use and habitat selection in managed coniferous boreal forests of eastern Canada. 
Journal of Wildlife Management, 77(4), 749-760.

https://doi.org/10.1002/jwmg.511

Colwell, R. K. 2013. EstimateS: Statistical estimation of species richness and shared species from samples. Version 9. User's Guide and application published at: http://purl.oclc.org/estimates.

DeGraaf, Richard M.; Yamasaki, Mariko; Leak, William B.; Lester, Anna M. 2006. Technical guide to forest wildlife habitat management in New England. Burlington, VT: University of Vermont Press, and Hanover, NH: University Press of New England. 305 p

Dey, D. C., Brissette, J. C., Schweitzer, C. J., \& Guldin, J. M. (2012). Silviculture of forests in the Eastern United States. 161(Helms 1998), 7-40. http://www.treesearch.fs.fed.us/pubs/41072\#.U94tJbVVA2U.mendeley

Dirzo, R., Young, H. S., Galetti, M., Ceballos, G., Isaac, N. J. B., \& Collen, B. (2014). Defaunation in the Anthropocene. Science, 345(6195), 401-406. https://doi.org/10.1126/science.1251817

Dunn, P. K., \& Smyth, G. K. (2005). Dispersion Model Densities. Statistics and Computing, 15(4), 267-280.

Fahrig, L. (2003). Effects of Habitat Fragmentation on Biodiversity. Annual Review of Ecology, Evolution, and Systematics, 34, 487-515. https://doi.org/10.1146/annurev.ecolsys.34.011802.132419

Franklin, J. F., Spies, T. A., Pelt, R. Van, Carey, A. B., Thornburgh, D. A., Berg, D. R., Lindenmayer, D. B., Harmon, M. E., Keeton, W. S., Shaw, D. C., Bible, K., \& Chen, J. (2002). Disturbances and structural development of natural forest ecosystems with silvicultural implications, using Douglas-fir forests as an example. Forest Ecology and Management, 155(1-3), 399-423. https://doi.org/10.1016/S0378-1127(01)00575-8

Gehring, T. M., McFadden, L. M., Prussing, S. A., Bickersmith, S. A., Buchanan, C., Nelson, E., \& Swanson, B. J. (2019). Spatial ecology of re- introduced american martens in the northern lower peninsula of michigan. The American Midland Naturalist, 182(2), 239-251.

Gosse, J. W., Cox, R., \& Avery, S. W. (2005). Home-Range Characteristics and Habitat Use By American Martens in Eastern Newfoundland. Journal of Mammalogy, 86(6), 1156-1163. https://doi.org/10.1644/15451542(2005)86[1156:hcahub]2.0.co;2

Greenberg, C. H., \& Editors, B. S. C. (n.d.). Natural Disturbances and Historic Range of Variation.

Gross, J., Elvinger, F., Hungerford, L. L., \& Gehrt, S. D. (2012). Raccoon use of the urban matrix in the Baltimore Metropolitan Area, Maryland. Urban Ecosystems, 15(3), 667-682. https://doi.org/10.1007/s11252-011-0218-z

Habeck, C. W., \& Schultz, A. K. (2015). Community-level impacts of white-tailed deer on understorey plants in North American forests: a meta-analysis. AoB Plants, 7, plv119. https://doi.org/10.1093/aobpla/plv119

Henner, C. M., Chamberlain, M. J., Leopold, B. D., \& Burger, L. W. (2004). a MultiResolution Assessment of Raccoon Den Selection. Journal of Wildlife 
Management, 68(1), 179-187. https://doi.org/10.2193/0022-

541x(2004)068[0179:amaord]2.0.co;2

Hewitt, D. G. (2015). Hunters and the conservation and management of white-tailed deer (Odocoileus virginianus). International Journal of Environmental Studies, 72(5), 839-849. https://doi.org/10.1080/00207233.2015.1073473

Holloway G. L., \& Malcolm, J. R. (2006). Sciurid Habitat Relationships in Forests Managed Under Selection and Shelterwood Silviculture in Ontario. Journal of Wildlife Management, 70(6), 1735-1745. https://doi.org/10.2193/0022$541 \mathrm{x}(2006) 70[1735:$ shrifm $] 2.0 . \mathrm{co} ; 2$

Horsley, S. B., Stout, S. L., \& DeCalesta, D. S. (2003). White-tailed deer impact on the vegetation dynamics of a northern hardwood forest. Ecological Applications, 13(1), 98-118. https://doi.org/10.1890/10510761(2003)013[0098:WTDIOT]2.0.CO;2

Hradsky, B. A., Robley, A., Alexander, R., Ritchie, E. G., York, A., \& Di Stefano, J. (2017). Human-modified habitats facilitate forest-dwelling populations of an invasive predator, Vulpes vulpes. Scientific Reports, 7(1), 1-12. https://doi.org/10.1038/s41598-017-12464-7

Hupperts, S. F., Dickinson, Y. L., Webster, C. R., \& Kern, C. C. (2019). Promoting structural and species diversity in Great Lakes northern hardwoods: A conceptual model and its application. Forestry, 92(1), 16-25.

Jensen, P.G., Demers, C.L., Mcnulty, S.A., Jakubas, W.J. and Humphries, M.M. (2012), Marten and fisher responses to fluctuations in prey populations and mast crops in the northern hardwood forest. The Journal of Wildlife Management, 76: 489-502. doi:10.1002/jwmg.322

Johansson, K., Nilsson, U., \& Örlander, G. (2013). A comparison of long-term effects of scarification methods on the establishment of Norway spruce. Forestry, 86(1), 91-98. https://doi.org/10.1093/forestry/cps062

Jorgensen, E. E. (2004). Small Mammal Use of Microhabitat Reviewed. Journal of Mammalogy, 85(3), 531-539. https://doi.org/10.1644/ber-019

Lashley, M.A., Harper, C.A., Bates, G.E. and Keyser, P.D. (2011), Forage availability for white-tailed deer following silvicultural treatments in hardwood forests. The Journal of Wildlife Management, 75: 1467-1476. doi:10.1002/jwmg.176

Kaminski, J. A., Davis, M. L., Kelly, M., \& Keyser, P. D. (2007). Disturbance Effects on Small Mammal Species in a Managed Appalachian Forest. The American Midland Naturalist, 157(2), 385-397. https://doi.org/10.1674/00030031(2007)157[385:deosms]2.0.co;2

Kellner, K. F., Renken, R. B., Millspaugh, J. J., Porneluzi, P. A., Wolf, A. J., Fantz, D. K., Gitzen, R. A., Faaborg, J., Timm, S. R., Ehlers, S., Buchanan, M. L., Haslerig, J. M., George, A. D., \& Rota, C. T. (2019). Effects of forest management on vertebrates: synthesizing two decades of data from hardwood forests in Missouri, USA. Ecological Applications, 29(8), 1-16. https://doi.org/10.1002/eap.1993

Kellner, K. F., \& Swihart, R. K. (2014). Changes in Small Mammal Microhabitat Use Following Silvicultural Disturbance. The American Midland Naturalist, 172(2), 348-358. https://doi.org/10.1674/0003-0031-172.2.348 
Kern, C. C., Schwarzmann, J., Kabrick, J., Gerndt, K., Boyden, S., \& Stanovick, J. S. (2019). Mounds facilitate regeneration of light-seeded and browse-sensitive tree species after moderate-severity wind disturbance. Forest Ecology and Management, 437(October 2018), 139-147. https://doi.org/10.1016/j.foreco.2018.12.040

Keeton, W. S. (2006). Managing for late-successional/old-growth characteristics in northern hardwood-conifer forests. Forest Ecology and Management, 235(1-3), 129-142. https://doi.org/10.1016/j.foreco.2006.08.005

Kirby, R. B., Muller, L. I., Chamberlain, M. J., \& Conner, M. (2017). Hardwood management and restoration of longleaf pine ecosystems may affect raccoon daytime resting sites. Restoration Ecology, 25(3), 424-431.

https://doi.org/10.1111/rec.12455

Kuijper, D. P. J., Cromsigt, J. P. G. M., Churski, M., Adam, B., Jedrzejewska, B., \& Jedrzejewski, W. (2009). Do ungulates preferentially feed in forest gaps in European temperate forest? Forest Ecology and Management, 258(7), 15281535. https://doi.org/10.1016/j.foreco.2009.07.010

Kuijper, D. P. J. (2011). Lack of natural control mechanisms increases wildlifeforestry conflict in managed temperate European forest systems. European Journal of Forest Research, 130(6), 895-909. https://doi.org/10.1007/s 10342011-0523-3

Kurta, A. (2017). Mammals of the Great Lakes Region, 3rd ed. University of Michigan Press, Ann Arbor, Michigan, xii + 404 pp. ISBN: 978-0-472-05345

Lashley, M. A., Harper, C. A., Bates, G. E., \& Keyser, P. D. (2011). Forage availability for white-tailed deer following silvicultural treatments in hardwood forests. Journal of Wildlife Management, 75(6), 1467-1476. https://doi.org/10.1002/jwmg.176

Lavoie, M., Renard, A., \& Larivière, S. (2019). Timber harvest jeopardize marten persistence in the heart of its range. Forest Ecology and Management, 442(January), 46-52. https://doi.org/10.1016/j.foreco.2019.03.060

Leak, W. B., Yamasaki, M., \& Holleran, R. (2014). Silvicultural Guide for Northern Hardwoods in the Northeast. USDA Forest Service General Technical Report NRS-132, April, 46.

Leblond, M., Dussault, C., \& Ouellet, J. P. (2013). Impacts of human disturbance on large prey species: do behavioral reactions translate to fitness consequences? PloS One, 8(9). https://doi.org/10.1371/journal.pone.0073695

Manning, J. A., \& Edge, W. D. (2004). Small Mammal Survival and Downed Wood at Multiple Scales in Managed Forests. Journal of Mammalogy, 85(1), 87-96. https://doi.org/10.1644/1545-1542(2004)085<0087:smsadw>2.0.co;2

Massé, A., \& Côté, S. D. (2009). Habitat Selection of a Large Herbivore at High Density and Without Predation: Trade-off between Forage and Cover? Journal of Mammalogy, 90(4), 961-970. https://doi.org/10.1644/08-mamm-a-148.1

Miller, G. W., \& Baumgras, J. E. (1994). Efficient silvicultural practices for eastern hardwood management. Proc. of the Twenty-Second Ann. Hrwd. Symposium: Oppor. for the Hardwood Industry to Address Environmental Challenges., 2335. 
Moriarty, K. M., Epps, C. W., \& Zielinski, W. J. (2016). Forest thinning changes movement patterns and habitat use by Pacific marten. Journal of Wildlife Management, 80(4), 621-633. https://doi.org/10.1002/jwmg.1060

Newbury, R. K., \& Nelson, T. A. (2007). Habitat Selection and Movements of Raccoons on a Grassland Reserve Managed for Imperiled Birds. Journal of Mammalogy, 88(4), 1082-1089. https://doi.org/10.1644/06-mamm-a-192r2.1

Niedballa J, Sollmann R, Courtiol A, Wilting A (2016). "camtrapR: an R package for efficient camera trap data management." Methods in Ecology and Evolution, 7(12), 1457-1462. doi: 10.1111/2041-210X.12600, https://besjournals.onlinelibrary.wiley.com/doi/full/10.1111/2041-210X.12600.

National Oceanic and Atmospheric Administration [NOAA] (2018) August 2017 Monthly Climatic Data for the World, (ISSN 0027-0296) NOAA 70:8

Nolet, P., Kneeshaw, D., Messier, C., \& Béland, M. (2018). Comparing the effects of even- and uneven-aged silviculture on ecological diversity and processes: A review. Ecology and Evolution, 8(2), 1217-1226. https://doi.org/10.1002/ece3.3737

Patton, S. R., Russell, M. B., Windmuller-Campione, M. A., \& Frelich, L. E. (2018). Quantifying impacts of white-tailed deer (Odocoileus virginianus Zimmerman) browse using forest inventory and socio-environmental datasets. PLoS ONE, 13(8), 1-16. https://doi.org/10.1371/journal.pone.0201334

Rawinski, T. J.. (2008). Impacts of White-Tailed Deer Overabundance in Forest Ecosystems: An Overview. Northeastern Area State and Private Forestry Forest Service, U.S. Department of Agriculture.

Ritchie, E. G., \& Johnson, C. N. (2009). Predator interactions, mesopredator release and biodiversity conservation. Ecology Letters, 12(9), 982-998. https://doi.org/10.1111/j.1461-0248.2009.01347.x

Rooney, T. P., \& Waller, D. M. (2003). Direct and indirect effects of white-tailed deer in forest ecosystems. Forest Ecology and Management, 181(1-2), 165-176. https://doi.org/10.1016/S0378-1127(03)00130-0

Rosenzweig, M. L., \& Winakur, J. (1969). Population Ecology of Desert Rodent Communities : Habitats and Environmental Complexity. Wiley Stable, 50(4), $558-572$.

RStudio Team (2020). RStudio: Integrated Development for R. RStudio, PBC, Boston, MA URL http://www.rstudio.com/.

Russell, M. B., Woodall, C. W., Potter, K. M., Walters, B. F., Domke, G. M., \& Oswalt, C. M. (2017). Interactions between white-tailed deer density and the composition of forest understories in the northern United States. Forest Ecology and Management, 384, 26-33. https://doi.org/10.1016/j.foreco.2016.10.038

Stirnemann, I., Mortelliti, A., Gibbons, P., \& Lindenmayer, D. B. (2015). Fine-scale habitat heterogeneity influences occupancy in terrestrial mammals in a temperate region of Australia. PLoS ONE, 10(9), 1-16. https://doi.org/10.1371/journal.pone.0138681

Sturtevant, B. R., and J. A. Bissonette. (1997). Stand structure on microtine abundance in Newfoundland: implications for marten. Pages 182-198 in G. Proulx, H. N. 
Bryant, and P. M. Woodard, eds. Martes: taxonomy, ecology, techniques, and management. Provincial Mus. Alberta, Edmonton.

Suffice, P., Asselin, H., Imbeau, L., Cheveau, M., \& Drapeau, P. (2017). More fishers and fewer martens due to cumulative effects of forest management and climate change as evidenced from local knowledge. Journal of Ethnobiology and Ethnomedicine, 13(1), 1-14. https://doi.org/10.1186/s13002-017-0180-9

Tilghman, N. (1989). Impacts of White-Tailed Deer on Forest Regeneration in Northwestern Pennsylvania. The Journal of Wildlife Management, 53(3), 524532. doi: $10.2307 / 3809172$

Tinya, F., Kovács, B., Prättälä, A., Farkas, P., Aszalós, R., \& Ódor, P. (2019). Initial understory response to experimental silvicultural treatments in a temperate oakdominated forest. European Journal of Forest Research, 138(1), 65-77. https://doi.org/10.1007/s10342-018-1154-8

Thompson, I. D. (1988). Habitat Needs of Furbearers in Relation to Logging in Boreal Ontario. The Forestry Chronicle, 64(3), 251-261. https://doi.org/10.5558/tfc64251-3

Von Trebra, C., Lavender, D., \& Sullivan, T. (1998). Relations of Small Mammal Populations to Even-Aged Shelterwood Systems in Sub-Boreal Spruce Forest. The Journal of Wildlife Management, 62(2), 630-642. doi:10.2307/3802339

Walter, T., Zink, R., Laaha, G., Zaller, J. G., \& Heigl, F. (2018). Fox sightings in a city are related to certain land use classes and sociodemographics: Results from a citizen science project. BMC Ecology, 18(1), 1-11. https://doi.org/10.1186/s12898-018-0207-7

Walton, Z., Samelius, G., Odden, M., \& Willebrand, T. (2017). Variation in home range size of red foxes Vulpes vulpes along a gradient of productivity and human landscape alteration. PLoS ONE, 12(4), 1-14. https://doi.org/10.1371/journal.pone.0175291

Yamasaki, M., Costello, C. A., \& Leak, W. B. (2014). Effects of Clearcutting, Patch Cutting, and Low-density Shelterwoods on Breeding Birds and Tree Regeneration in New Hampshire Northern Hardwoods. United States Department of Agriculture

Zaczek, J. J., Harding, J., \& Welfley, J. (1994). Impact of Soil Scarification on the Composition of Regeneration. 341-348.

Zielinski, W. J., Slauson, K. M., Carroll, C. R., Kent, C. J., \& Kudrna, D. G. (2001). Status of American Martens in Coastal Forests of the Pacific States. Journal of Mammalogy, 82(2), 478-490. https://doi.org/10.1644/15451542(2001)082<0478:soamic >2.0.co;2

Zwolak, R. (2009). A meta-analysis of the effects of wildfire, clearcutting, and partial harvest on the abundance of North American small mammals. Forest Ecology and Management, 258(5), 539-545. https://doi.org/10.1016/j.foreco.2009.05.033 


\section{Literature Review: Moving toward iDNA studies in the hardwood forests of North America by utilizing ticks and mosquitoes.}

\subsection{Introduction}

As the human population increases, anthropogenic activity modifies the landscape through activities such as mining, settlements, farming, and road construction. These human disturbances affect mammal habitats, which can lead to biodiversity loss, mammal population declines, and shifts in mammal community compositions (Fahrig 2003). Within environmental sciences, a community is defined as a group of interacting species which includes plants, insects, and other animal species; however a mammalian community is more nuanced as it looks only at the interacting mammals within a given system (Stroud et al. 2015).

Changes in a community can cause a 'species-level cascade' or even a 'communitylevel cascade' (Polis et al. 2000). A cascade occurs when a single species' population significantly changes or becomes extinct, which can then lead to changes in other species' populations. When the change in the community affects only a subset of the community, it is termed a species-level cascade; when the change affects the entire community from the top predator to the plant biomass, it is considered a communitylevel cascade (Polis et al. 2000). Both species-level and community-level cascades can impact the mammal species. This impact may be an increase in mammalian diseases by introducing new species with new diseases into the system (Ostfield and Keesing 2000). Community shifts may cause a change in resource availability by removing a species that was a staple of the ecosystem or by introducing a new species that is in competition with local species. The cascades can even lead to the extinction of a species through competition or lack of resources (Wood et al. 2015). Therefore, understanding and monitoring changes in mammalian community composition is an important step in the conservation and management of an ecosystem.

There are many techniques to monitor mammalian community composition. One method of noninvasive sampling that is often used is camera trap studies. Camera trap studies utilize a camera with a motion sensor that takes a photo of wildlife when it passes the camera. These cameras can be used to capture the habits of specific species by placing a camera within the habitat in question, monitor rare species, and monitor nocturnal mammals (Roveroa 2013). This technique can be used for a single species or full mammalian community compositions. However, camera traps have a limited view, which can result in missing or falsely identifying small and arboreal mammals (Roveroa 2013; Hobbes and Brehme, 2017). However, when the camera traps are used in tandem with other techniques a more comprehensive view of the mammal community can be observed. 
Another method of noninvasive monitoring is genetic noninvasive sampling which relies on genetic material left behind by mammals. By collecting genetic material such as fecal samples, urine, or fur, the mammal species' DNA can be extracted and identified (Ferreira, et al. 2018, Waits, et al. 2005). There are many genetic techniques used to look for information on individuals within a population. Microsatellites and single nucleotide polymorphisms (SNPs) are commonly used in noninvasive genetic sampling. These markers can be used to genotype individuals and estimate genetic diversity within a population (Ferreira, et al. 2018). However, these genetic analyses often focus on one or just a few species and are not well suited for finding mammalian community composition (Cristescu et al. 2014).

One subset of genetic monitoring techniques that can be used to determine mammalian community composition is environmentally-derived DNA (eDNA). eDNA is extracted from something in the environment such as water or dirt. DNA is extracted, specific genomic regions (mitochondrial or nuclear) are amplified and sequenced in an attempt to identify all the species that were within the study environment (Rees, et al.

2014). Unlike other noninvasive genetic studies that often utilize microsatellites or SNPs to identify individuals of the same species, eDNA studies utilize metabarcodes that identify all the species in an environmental sample. Metabarcoding is a taxaspecific process that utilizes primers that amplify conserved loci that are found in all mammals or groups of mammals (Figure 3.1). Segments of genes, mitochondrial genes are most commonly used, are amplified and sequenced. These genes have specific evolutionary history leading to conserved genetic variants that can be used to identify the genus or species by comparing the sequence to a DNA database. Through multiple sampling, extraction, sequencing, and genotyping, the community composition of the mammals in that specific environment can be assessed.

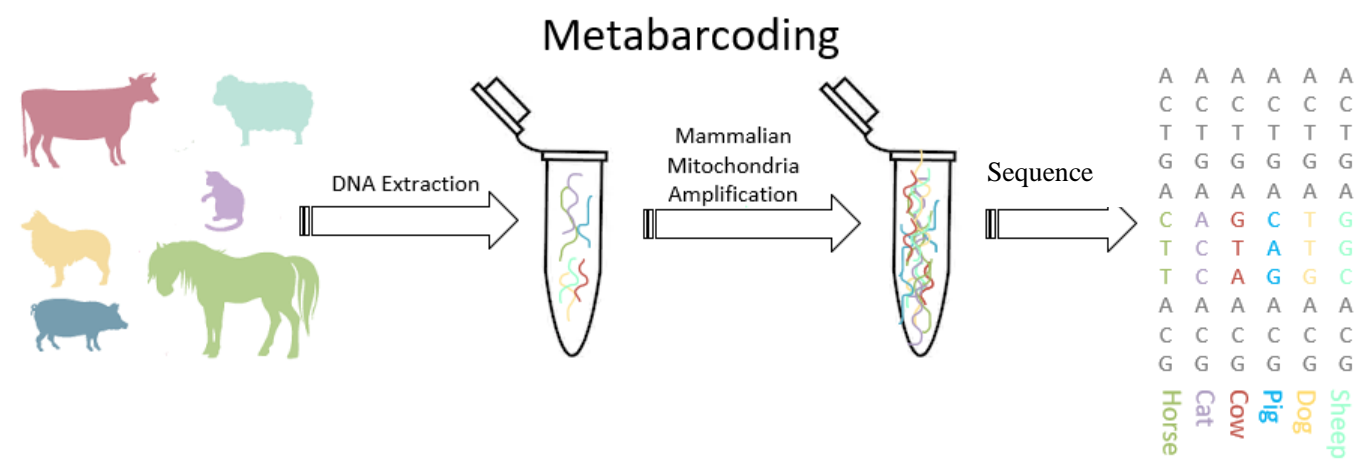

Figure 3.1. Metabarcoding is a taxa-specific process that utilizes primers that amplify conserved loci that are found in all mammals or groups of mammals. This is done by extracting DNA from a source such as water then amplifying a conserved region of the DNA. Then the amplified region is sequenced. The sequences are analyzed and compared to a database to identify the species. 
A new subset of eDNA, invertebrate-derived DNA (iDNA), is a way to monitor mammal communities terrestrially because it focuses on identifying the mammalian host of blood-sucking, feces consuming, and carrion-eating invertebrates (Bohmann et al. 2014). Identification is accomplished by extracting DNA from the meal taken by invertebrates from their host. Once extracted, the host DNA is identified by amplifying and sequencing a mammalian gene segment, and then comparing the sequence to a DNA database to identify the mammalian hosts (Bohmann et al. 2014). This process utilizing iDNA allows for a large range of mammals to be identified within a mammalian community since the blood-sucking invertebrates can have the blood of multiple host mammals in a single environment. Invertebrates are also present in large numbers allowing for the collection of multiple invertebrates in a single capture event. However, some invertebrates have specific preferences that can limit the species detected as outlined in more detail below in section 3.2.2.

\section{2 iDNA}

\subsubsection{Detection Success}

The process of collecting iDNA has been successfully used from a wide range of invertebrates, such as leeches, blowflies, mosquitoes, and ticks to identify different vertebrate species within a mammalian community. These studies have shown that DNA can be extracted from a blood-meal, feces, or cadavers and used to identify mammal populations. Early studies focused on demonstrating the possibility of extracting host DNA from invertebrates to identify mammals at varying taxonomy levels (Molaei et al 2007), while more recent studies investigated the number of detectable hosts and quantified a mammalian community (Logue et al. 2016).

Logue et al. (2016) demonstrated that multiple host's DNA could be extracted and identified from individual mosquitoes. Focusing on six mammalian groups, they found an individual mosquito had to have up to three identifiable hosts (Logue, et al. 2016). For example, a single mosquito was found to have marsupial, human, and porcine DNA in their blood meal, while another mosquito had only dog and human DNA in their blood meal (Logue, et al. 2016). The ability to detect multiple hosts suggests iDNA may be a good tool to monitor mammal communities because there is not a 1:1 ratio between invertebrates captured and vertebrates detected with the possibility of capturing hundreds of invertebrates. The increased ratio allows researchers to collect a larger range of hosts with fewer individual invertebrates.

\subsubsection{Comparative Studies}

Comparative studies were conducted to show the efficiency of iDNA compared to camera traps. Data collected from blowfly iDNA was compared to data collected from camera traps in multiple tropical studies in southern Asia, South America, and Central America. Rodgers et al. (2017) found that four species were detected by blowfly- 
derived iDNA that were missed by camera traps in a study conducted in Panama. These species were considered rare captures including the Stripe-headed round-eared bat (Tonatia saurophila) and Derby's woolly opossum (Caluromys derbianus). However, in the same study blowfly-derived iDNA did not detect three abundant species including the Central American red brocket deer (Mazama temama) which was spotted over 4000 times in the camera traps (Rodgers, et al. 2017). Lee et al. (2016) utilized blowfly iDNA in Malaysia and found similar patterns in their study, noting that common species were missed with iDNA, suggesting that the blowfly feeding preference may target species not always easily detected on cameras. When comparing the blowfly derived iDNA and camera traps, these two studies found that iDNA did identify species not detected on camera traps. However, the iDNA method did not detect common species that camera traps captured in both of the studies (Lee et al. 2016, Rodgers et al. 2017). The findings of these studies suggest that blowfly-derived iDNA studies can be beneficial to identify species composition used in conjunction with camera traps.

Other studies utilized leech-derived iDNA collected from land leeches to compare with the findings of camera traps. Wieskopf et al. (2018) conducted a study in Bangladesh and found that the species identified varied between leech-derived iDNA and camera traps (Figure 3.2). Species not detected on camera traps were detected through the leech-derived iDNA. For example, leech-derived iDNA detected the crab-eating mongoose (Herpestes urva) and gray wolf (Canis lupus) which camera traps missed. However, camera traps detected northern red muntjac (Muntiacus vaginalis) and large Indian civet (Viverra zibetha) which iDNA missed. There were a few species such as cows (Bos taurus) detected in both. Abrams et al. (2018) found that the leeches' effectiveness was dependent on the species of the leech. Each leech species had specific mammals it fed off of and the preferential feeding lead to brown leeches (Haemadipsa zeylanica) having DNA from less abundant mammal species, while more abundant species within the mammalian community were detected through tiger leeches (Haemadipsa picta; Abrams et al. 2018). The host preference directly affects the species found when utilizing iDNA which can limit the mammals detected.

\subsubsection{Current Limitations}

While iDNA has been shown to be a useful tool in monitoring mammals, there are limitations. This process is limited by the ecology of the invertebrates being used in an iDNA study. The invertebrates' ecology can influence the distance traveled from initial host contact, host preference, and time the meal was digesting (Abrams et al. 2018). These biological processes can factor into the amount and quality of DNA collected, affecting the results of a study.

The distance the invertebrate can travel after feeding affects the possible location of the mammals detected. Different species of invertebrates can travel different distances, and these distances can be difficult to estimate. An example of this has been shown for the 


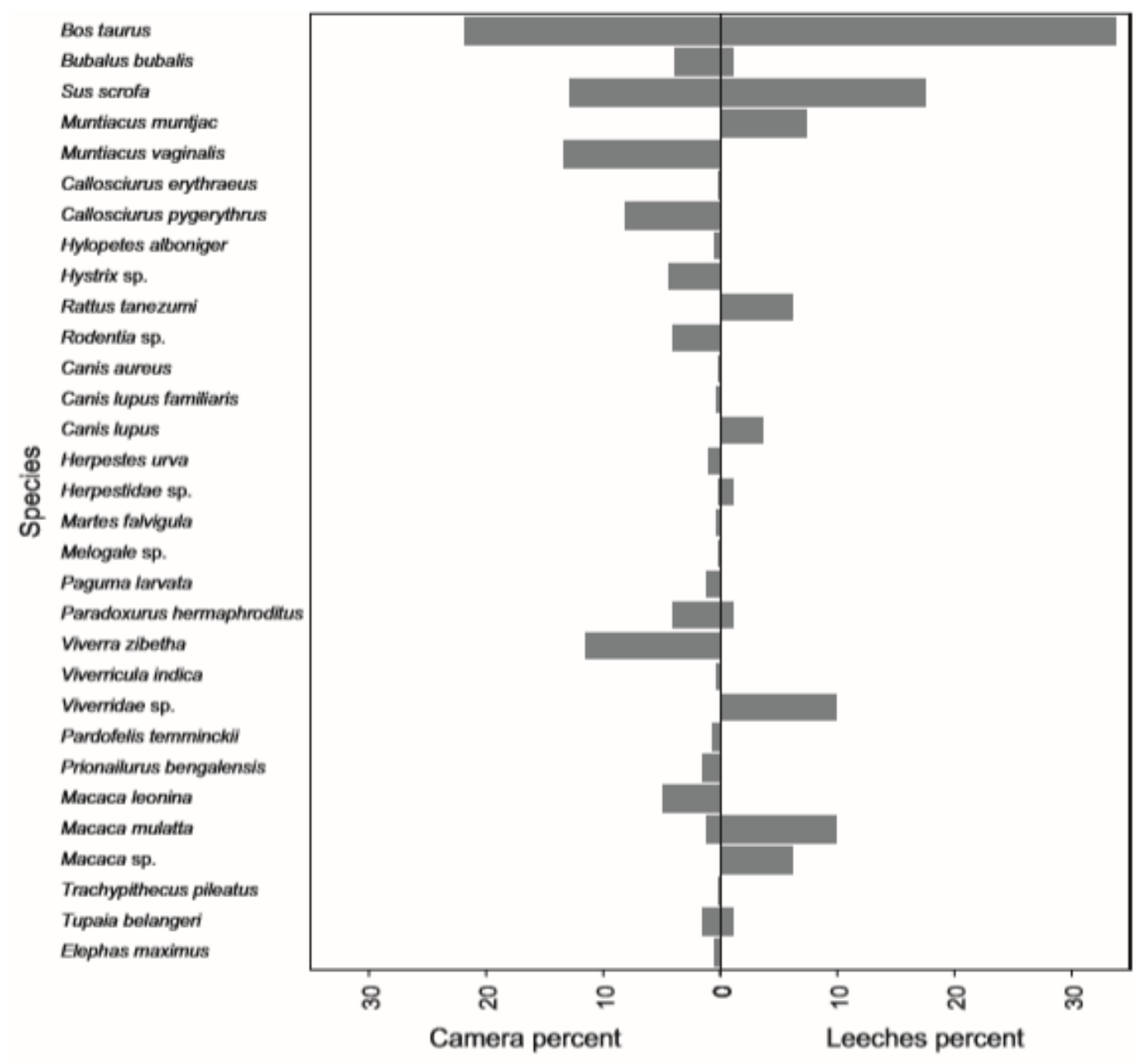

Figure 3.2. In northeastern Bangladesh, camera traps were compared to leech-derived iDNA. Camera traps were within $200 \mathrm{~m}$ of leech collection locations. Comparison of camera and leech iDNA species detection rates. The study was conducted in southeast Asia utilizing land leeches. (Weiskopf, McCarthy et al. 2018)

distance mosquitoes traveled (Figure 3.3) (Greenberg et al. 2012). Greenberg et al. (2012) found that Aedes vexans traveled an average of 109.2 meters while Culex quinquedascaitus traveled an average of 91.4 meters. Due to the differences in travel distance within a species, it is difficult to claim an animal was in a specific habitat just because an invertebrate was found in the habitat. 


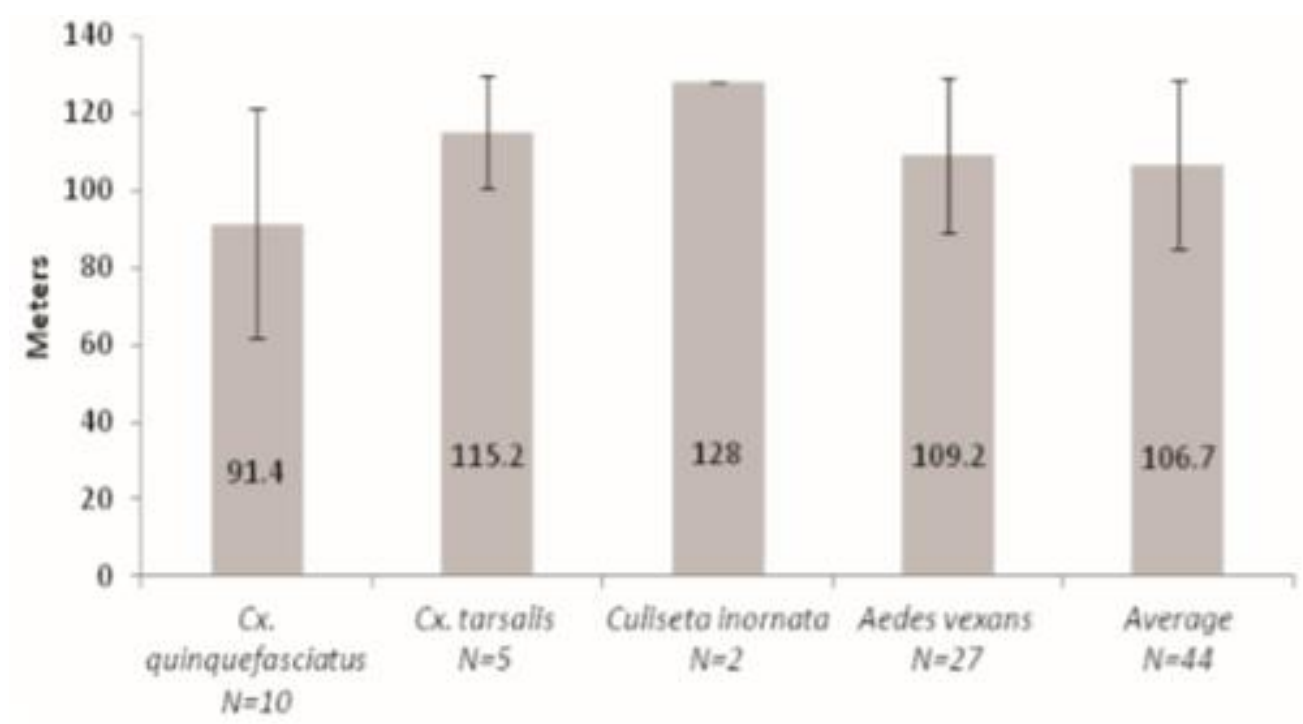

Figure 3.3. The distance traveled by different species of mosquitoes at a zoo in New Mexico zoo. Distances ranged from $91.4 \mathrm{~m}$ to $128 \mathrm{~m}$ based on species of mosquito. (Greenberg, DiMenna et al. 2012)

Along with variation in distance traveled, most species of invertebrates seem to have a host preference, a phenomenon that has been suggested by many studies (Lee et al. 2016, Abrams et al. 2018). However, research has not yet identified the particular preferences of each of the invertebrate species used in iDNA studies. Invertebrate host preference will, therefore, limit the taxa that iDNA can detect. Host preference limitation seems to be a factor in why some iDNA studies miss common species.

\section{3 iDNA: Hardwood Forests in the Great Lakes region of North America}

\subsubsection{Invertebrate choice}

The efficacy of iDNA studies may be enhanced through increasing sampling efforts in new regions, such as temperate zones in North America. The first step in expanding iDNA studies is choosing an invertebrate species. Choosing an invertebrate species or species group to collect from which to extract host DNA is a crucial part of an iDNA study. There are three requirements for picking an invertebrate species. The first requirement is the invertebrate species must feed on vertebrate tissues. For example, a leech feeds on blood and a carrion fly feeds on tissue and fecal matter; these meals are the source of vertebrate DNA (Schnell et al. 2015; Rodgers et al., 2017). The second requirement is that the invertebrate has a wide range of hosts. Ideally, the invertebrate will be a generalist and feed indiscriminately between vertebrates. A strong host preference can cause a vertebrate detection bias, as previously discussed. For example, if a leech prefers larger hosts over smaller hosts, the study will detect large hosts and will miss the smaller hosts (Abrams et al., 2018). The last requirement is that there 
should be a large number of the target invertebrate species present in an area. Host preference is linked to the species being collected, so by utilizing more invertebrates you allow for a larger range of detection and a higher chance of identifying a complete community. In the northern hardwood forests of the Great Lakes region of North America, there are two invertebrates that cover most of the requirements: hard ticks and mosquitoes.

Hard ticks (Ixodes) are abundant in the hardwood forests in the Great Lakes region of North America. There are 23 species of ticks found in this region that feed on mammals, the five most abundant are blacklegged tick (Ixodes scapularis), brown dog tick (Rhipicephalus sanguineus), woodchuck tick (Ixodes cookei), American dog tick (Dermacentor variabilis), and lone star tick (Amblyomma americanum) (Walker et al. 1998). There are two key features that make hard ticks good candidates for iDNA studies: they store blood and feed on multiple hosts. Ticks can store blood for many months to years without digesting the vertebrate meal (Sonenshine 2014). The undigested blood-meal could be used to detect host DNA months after feeding has occurred allowing for a higher chance of detecting a host vertebrate species.

Additionally, most of these ticks are considered three-host obligates, where they feed on three separate hosts during the duration of their life cycle. This allows host DNA to be extracted from every life stage increasing the likelihood of detecting host DNA. This makes it possible to detect multiple vertebrates with a single invertebrate.

Mosquitoes (Culicidae) are another abundant invertebrate in the hardwood forests of the Great Lakes region of North America with 40 different species (Darsie and Ward, 2005). Unlike ticks, mosquitoes feed on a vertebrate meal during only a portion of their life cycle where female mosquitoes require a blood meal to reproduce. However, it is important to note that females do not die after laying eggs. The female mosquito will search for a new host after laying her eggs which allows for the possibility of more than one host being identified for each engorged female mosquito captured (Logue, et. al, 2016). However, some mosquitoes have shown to have more host preference than others, but they will seek non-preference hosts when the preferred host is unavailable. Female mosquitoes have a generalized hunting strategy and have a plastic host preference based on species (Chaves et al. 2010). For example, Anopheles gambiae seeks a human host, but will target other mammalian species if humans are not readily available making them generalist feeders (Chaves et al. 2010). This suggests that there may be a small skew in host detection, that should be considered when used in an iDNA study.

\subsubsection{Invertebrate capture}

After selecting an invertebrate group to collect and extract DNA from, it is important to create an unbiased collection protocol. For ticks, tick sweeping is commonly used to collect specimens (Chong, et al. 2013). Tick sweeping is a process of dragging a canvas or sheet along tall grasses where ticks are often questing or are looking for a place to molt. The ticks hold onto the canvas and are removed with sterile tweezers. The 
collection should be completed at dawn and dusk because those are the times that ticks are most likely to have recently released from a host and before they begin molting (Wikel 2014, Barton et al. 1996). For an iDNA study, the timing is important because there is a higher chance a partially or fully engorged tick has recently fallen in that area due to their restricted movement (Sonenshine 2014). Once the ground is swept, it is likely that ticks of all stages in their life cycle will be collected since hard ticks feed at every stage.

There are three types of common capture techniques utilized when collecting blood-fed female mosquitoes. The first mosquito capture technique is a gravid trap. A gravid trap relies on stinky water, a mixture of sugar, yeast, and water, to draw mosquitoes wanting to lay their eggs (Molaei 2008, Crans 2004). However, this only works for Cx. pipiens type life cycles and limits the mosquito species that can be captured. The second mosquito capture technique is a CDC light trap. A CDC light trap utilizes a light source to draw in mosquitoes that then get trapped (Williams and Gingring, 2007). The CDC light trap works on a wider range of mosquito species, but draws in unfed mosquitoes, male mosquitoes, and other insects making the sorting process of mosquitoes more important and making this technique more invasive as more invertebrates die in the process. The third technique is resting boxes. This technique uses a man-made box or a natural resting point where mosquitos rest or where they land to rest temporarily. While resting, the mosquito is captured through an invertebrate collection vacuum. While the standing resting box method works, it relies on the researcher to wait and collect more often for fewer mosquitoes (Williams and Gingring 2007).

\subsection{Application in Northern Hardwoods}

An important step of iDNA studies is to understand the effect of invertebrate ecology on the capture rate of invertebrates. For example, tropical regions have a stable temperature, while temperate zones' large temperature fluctuations between seasons cause many invertebrates to have a diapause or pause in development during the colder months and a rapid life cycle in the warmer months (Sonenshine 2014). This limits collection times for invertebrates in temperate zones. Understanding an invertebrate's life cycle is the first step in understanding how to collect invertebrates in a region. However, other influences such as soil water content, and canopy cover can influence the capture of the invertebrates. A better understanding of factors influencing invertebrates collection can lead to a more effective tool by decreasing the sampling effort required.

To investigate the efficiency of using ticks and mosquitoes in an iDNA study located in the northern hardwood forests of the Great Lakes region of North America in Baraga County, of Michigan's Upper Peninsula, I collected both hard ticks and mosquitoes in the summer of 2019. My study region was located near Lake Superior, the largest of the United States' Great Lakes. I utilized different silviculture treatment sites that were part of a research study, the Northern Hardwood - Silvicultural Experiment for Enhancing 
Diversity (NHSEED). At these sites there were three understory treatments and six canopy treatments for a total of eighteen combined treatment-types.

I utilized tick sweeping to collect ticks. Tick sweeping is the process of dragging a sheet through areas with ticks, the ticks then cling to the sheet and are collected from there. I swept a total of 14,519 meters in different sites. To help inform future iDNA efforts, I evaluated how environmental factors influenced mosquito capture from the CDC light traps. I ran multiple linear regressions with the following environmental factors: canopy openness, soil water content, percent exposed soil, and month of collection. These factors were obtained from Dr. Yvette Dickinson's research team studying environmental factors at NHSEED. The environmental factors were collected in two $15 \mathrm{~m} 2$ circular sampling plots within each site. Canopy openness was collected by taking a photo of the canopy at the given plot. Then they used the "Gap light Analyzer" software to analyze these photos and calculate canopy openness. Soil water content was recorded once per month during the growing season with a Theta Probe Soil Moisture Sensor (Delta-T Devices Ltd., Cambridge UK) in each sampling plot. The percent exposed soil are ocular estimates of visible soil in the sampling plots, estimated using eight cover classes: $1 \%$; 2-5\%; 6-10\%; 11-25\%; 26-50\%; 51-75\%; 7695\%; and 96-100\% and the mid-point of each cover class was used for analysis.

Mosquitoes were collected utilizing CDC light traps and gravid traps in the middle of each site overnight. Gravid traps were out for 22 nights at different sites. CDC light traps were out for 40 nights at different sites. To analyze the factors that play a role in mosquito collection, I utilized data drege from the R package MuMIn (Barton, 2009). This resulted in multiple models that were superior to the null model, which is a model that lacks explanatory variables and was used to make sure the effect of the explanatory variables is better than the no variables (Table 3.1). I ranked the models based on their correct Akaike's Information Criterion (AICc) and model weight (AICc wi). I selected the top model with the lowest number of parameters and a delta Akaike's Information Criterion above 2 (Arnold, 2010).

Table 3.1. Linear models used to identify the environmental effects of collecting mosquitoes in the hardwood forests of the Great Lakes region of North America. Corrected Akaike Information Criterion (AICc) was used to identify the best model. Degrees of freedom were shown as df. The Corrected Akaike Information Criterion weight was shown as AICc wi.

\begin{tabular}{lcccccccc}
\multicolumn{1}{c}{ Model } & Intercept & $\begin{array}{c}\text { Exposed } \\
\text { Soil }\end{array}$ & $\begin{array}{c}\text { Canopy } \\
\text { Openness }\end{array}$ & Month & SWC & df & $\begin{array}{c}\Delta \\
\text { AICc }\end{array}$ & $\begin{array}{c}\text { AICc } \\
w i\end{array}$ \\
\hline $\begin{array}{l}\sim \text { Openness+ } \\
\text { Month } \\
\sim \text { Openness+ } \\
\text { Month+SW }\end{array}$ & 6.79 & & 0.01 & -0.73 & & 3 & 0.00 & 0.46 \\
$\begin{array}{l}\text { C } \\
\text { ExposedSo }\end{array}$ & 6.84 & 0.28 & 0.01 & -0.75 & & 4 & 1.95 & 0.17 \\
$\begin{array}{l}\text { il+Openness } \\
+ \text { Month }\end{array}$ & & & 0.01 & -0.76 & 0.01 & 4 & 1.30 & 0.24 \\
\end{tabular}




\begin{tabular}{|c|c|c|c|c|c|c|c|c|}
\hline $\begin{array}{l}\text { ExposedSo } \\
\text { il+Openness } \\
+ \text { Month+S } \\
\text { WC }\end{array}$ & 6.49 & 0.50 & 0.01 & -0.79 & 0.02 & 5 & 2.52 & 0.13 \\
\hline$\sim$ Month & 6.62 & & & -0.63 & & 2 & 28.77 & 0.00 \\
\hline $\begin{array}{l}\sim \text { Month }+\mathrm{S} \\
\text { WC }\end{array}$ & 6.83 & & & -0.62 & -0.01 & 3 & 30.09 & 0.00 \\
\hline $\begin{array}{l}\text { ExposedSo } \\
\text { il+Month }\end{array}$ & 6.60 & -0.18 & & -0.63 & & 3 & 30.89 & 0.00 \\
\hline $\begin{array}{l}\text { ExposedSo } \\
\text { il+Month+S } \\
\text { WC }\end{array}$ & 6.83 & -0.30 & & -0.61 & -0.01 & 4 & 31.97 & 0.00 \\
\hline$\sim$ Light & 1.52 & & 0.01 & & & 2 & 45.29 & 0.00 \\
\hline $\begin{array}{l}\text { ExposedSo } \\
\text { il+Openness }\end{array}$ & 1.58 & -0.36 & 0.01 & & & 3 & 46.71 & 0.00 \\
\hline $\begin{array}{l}\text { Openness+ } \\
\text { SWC }\end{array}$ & 1.49 & & 0.01 & & 0.00 & 3 & 47.62 & 0.00 \\
\hline $\begin{array}{l}\text { ExposedSo } \\
\text { il+Openness } \\
+ \text { SWC }\end{array}$ & 1.70 & -0.40 & 0.01 & & 0.00 & 4 & 49.10 & 0.00 \\
\hline $\begin{array}{l}\text { ExposedSo } \\
\text { il+SWC }\end{array}$ & 2.64 & -0.75 & & & -0.02 & 3 & 59.59 & 0.00 \\
\hline Null & 1.95 & & & & & 1 & 60.94 & 0.00 \\
\hline$\sim \mathrm{SWC}$ & 2.34 & & & & -0.01 & 2 & 61.17 & 0.00 \\
\hline $\begin{array}{l}\text { ExposedSo } \\
\text { il }\end{array}$ & 2.02 & -0.51 & & & & 2 & 61.20 & 0.00 \\
\hline
\end{tabular}

Table 3.2. The top model from the 16 models used to identify the environmental effects of collecting mosquitoes in the hardwood forests of the Great Lakes region of North America. Beta values of the variables were shown as $\beta$. Standard error was shown as SE and the 95\% confidence level was shown as 95\% CL.

\begin{tabular}{ccccc}
\hline $\begin{array}{c}\text { Dependent } \\
\text { variable }\end{array}$ & $\begin{array}{c}\text { Explanatory } \\
\text { variable }\end{array}$ & $\beta$ & SE & $95 \%$ CL \\
\hline $\begin{array}{c}\text { Number of } \\
\text { Female } \\
\text { Mosquitoes }\end{array}$ & Canopy openness & -0.73 & 0.12 & $-0.97,-0.51$ \\
& Month & 0.012 & 0.002 & $0.01,0.016$ \\
\hline
\end{tabular}

For gravid traps, in 22 nights of collection only one mosquito was captured, while for CDC light traps, in 40 nights of collection 296 mosquitoes were captured. Of the mosquitoes collected most were considered un-engorged, suggesting they are questing for a host and not gravid. However, it is still possible to extract a blood meal and host 
DNA from an un-engorged mosquito (Logue, et. al, 2016). The discrepancy of the number of mosquitoes collected between different trap types was not observed in other studies (Williams and Gingring 2007), suggesting the most effective trap type is dependent on other environmental factors. This should be investigated more before choosing a trap type when collecting mosquitoes. Even within the same trap, there is an effect of environmental factors on the collection of mosquitoes. I found that canopy openness and month influence in the collection of mosquitoes where mosquitoes have a negative relationship with the canopy openness and a positive relationship with the collection month (Table 2). These results suggest the time of year and amount of canopy openness needs to be taken into consideration when collecting mosquitoes in hardwood forests. Areas with low canopy openness should be sampled more frequently compared to areas with high canopy openness.

I utilized tick sweeping in the summer of 2019 to collect ticks in the same experimental sites as mosquitoes. I swept a total of 14,519 meters and collected 22 ticks in total; this was less than expected. There are two possible reasons for low tick detection. The first is the possibility of a cold winter lowering the population of ticks. The polar vortex of the winter of 2018/2019 created an abnormally cold winter (Overland, et al. 2019). This could have killed a proportion of the ticks in diapauses. A mass death would temporarily decrease the number of questing ticks the following summer. The second possibility for low yield is the forest cover type influencing tick questing behavior. There has been evidence that the canopy cover influences the number of ticks collected (Ginsberg et al., 2020). We were sampling in different canopy cover percentages which may have influenced the number of ticks caught. Tick sweeping should be done more frequently and over more than one season to better understand how environmental factors influence tick collection.

\subsection{Next steps: iDNA in Northern Hardwoods}

Expanding iDNA to temperate zones by utilizing ticks and mosquitoes is a logical expansion of iDNA studies. Current studies have focused on tropical regions; however, this kind of study could be useful for monitoring community shifts in the temperate regions as well. Utilizing iDNA in temperate zones requires an understanding of the invertebrates in the system. To effectively collect mosquitoes and ticks, environmental factors need to be taken into consideration. Tick collection is dependent on the winter temperature, while mosquitoes are influenced by the month of collection and the openness of the canopy. These factors can be utilized to minimize the collection effort of invertebrates. After collection of these invertebrates, the blood meal needs to be extracted, amplified, sequenced, and analyzed. 


\subsection{References}

Abrams, J. F., Hoerig, L., Brozovic, R., Axtner, J., Crampton-Platt, A., Azlan, M., Wilting, A. (2018). Shifting up a gear with iDNA: From mammal detection events to standardized surveys. Cold Spring Harbor: Cold Spring Harbor Laboratory Press.

Barton, K. (2009) Mu-MIn: Multi-model inference. R Package Version 0.12.2/r18. http://R-Forge.R-project.org/projects/mumin/

Bohmann, Kristine, Alice Evans, M. Thomas, P. Gilbert, Gary R. Carvalho, Simon Creer, Michael Knapp, Douglas W. Yu, and Mark de Bruyn. 2014.

Environmental DNA for wildlife biology and biodiversity monitoring. Trends in Ecology and Evolution. 29(6)

Chaves, L. F., Harrington, L. C., Keogh, C. L., Nguyen, A. M., \& Kitron, U. D. (2010). Blood feeding patterns of mosquitoes: Random or structured? Frontiers in Zoology, 7, 1-11. https://doi.org/10.1186/1742-9994-7-3

Chong, S. T., Kim, H. C., Lee, I.-Y., Kollars, T. M., Sancho, A. R., Sames, W. J., \& Klein, T. A. (2013). Comparison of Dragging and Sweeping Methods for Collecting Ticks and Determining Their Seasonal Distributions for Various Habitats, Gyeonggi Province, Republic of Korea. Journal of Medical Entomology, 50(3), 611-618. https://doi.org/10.1603/me12032

Crans, W. J. (2004). A classification system for mosquito life cycles: life cycle types for mosquitoes of the northeastern United States. Journal of Vector Ecology : Journal of the Society for Vector Ecology, 29(1), 1-10. http://www.ncbi.nlm.nih.gov/pubmed/15266736

Cristescu, M. E. (2014). From barcoding single individuals to metabarcoding biological communities: Towards an integrative approach to the study of global biodiversity. Trends in Ecology and Evolution, 29(10), 566-571. https://doi.org/10.1016/j.tree.2014.08.001

Richard F. Darsie and Ronald A. Ward "Correction To: Identification And Geographical Distribution of the Mosquitoes of North America, North of Mexico," Journal of the American Mosquito Control Association 24(1), 108109, (1 March 2008). https://doi.org/10.2987/5706.1

Fahrig, L. (2003). Effects of Habitat Fragmentation on Biodiversity. Annual Review of Ecology, Evolution, and Systematics, 34, 487-515. https://doi.org/10.1146/annurev.ecolsys.34.011802.132419

Ferreira, C. M., Sabino-Marques, H., Barbosa, S., Costa, P., Encarnação, C., AlpizarJara, R., Pita, R., Beja, P., Mira, A., Searle, J. B., Paupério, J., \& Alves, P. C. (2018). Genetic non-invasive sampling (gNIS) as a cost-effective tool for monitoring elusive small mammals. European Journal of Wildlife Research, 64(4). https://doi.org/10.1007/s10344-018-1188-8

Ginsberg, H. S., Rulison, E. L., Miller, J. L., Pang, G., Arsnoe, I. M., Hickling, G. J., Ogden, N. H., LeBrun, R. A., \& Tsao, J. I. (2020). Local abundance of Ixodes scapularis in forests: Effects of environmental moisture, vegetation characteristics, and host abundance. Ticks and Tick-Borne Diseases, 11(1), 101271. https://doi.org/10.1016/j.ttbdis.2019.101271 
Greenberg, J. A., Dimenna, M. A., Hanelt, B., \& Hofkin, B. V. (2012). Analysis of post-blood meal flight distances in mosquitoes utilizing zoo animal blood meals. Journal of Vector Ecology, 37(1), 83-89. https://doi.org/10.1111/j.19487134.2012.00203.x

Hobbs, M. T., \& Brehme, C. S. (2017). An improved camera trap for amphibians, reptiles, small mammals, and large invertebrates. PLoS ONE, 12(10), 1-15. https://doi.org/10.1371/journal.pone.0185026

Lee, P. S., Gan, H. M., Clements, G. R., \& Wilson, J. J. (2016). Field calibration of blowfly-derived DNA against traditional methods for assessing mammal diversity in tropical forests 1 . Genome, 59(11), 1008-1022. https://doi.org/10.1139/gen-2015-0193

Lee, P. S., Sing, K. W., \& Wilson, J. J. (2015). Reading mammal diversity from flies: The persistence period of amplifiable mammal mtDNA in blowfly guts (Chrysomya megacephala) and a new DNA mini-barcode target. PLoS ONE, 10(4), 1-12. https://doi.org/10.1371/journal.pone.0123871

Logue, K., Keven, J. B., Cannon, M. V., Reimer, L., Siba, P., Walker, E. D., Zimmerman, P. A., \& Serre, D. (2016). Unbiased Characterization of Anopheles Mosquito Blood Meals by Targeted High-Throughput Sequencing. PLoS Neglected Tropical Diseases, 10(3), 1-18. https://doi.org/10.1371/journal.pntd.0004512

Molaei, G., Andreadis, T. G., Armstrong, P. M., \& Diuk-Wasser, M. (2008). HostFeeding Patterns of Potential Mosquito Vectors in Connecticut, USA: Molecular Analysis of Bloodmeals from 23 Species of Aedes, Anopheles, Culex, Coquillettidia, Psorophora, and Uranotaenia. Journal of Medical Entomology, 45(6), 1143-1151. https://doi.org/10.1603/00222585(2008)45[1143:hpopmv]2.0.co;2

Ostfeld, R. S., \& Keesing, F. (2000). Biodiversity and disease risk: The case of Lyme disease. Conservation Biology, 14(3), 722-728. https://doi.org/10.1046/j.15231739.2000.99014.x

Overland, J. E., \& Wang, M. (2019). Impact of the winter polar vortex on greater North America. International Journal of Climatology, 39(15), 5815-5821. https://doi.org/10.1002/joc.6174

Polis, G. A., Sears, A. L. W., Huxel, G. R., Strong, D. R., \& Maron, J. (2000). When is a trophic cascade a trophic cascade? Trends in Ecology and Evolution, 15(11), 473-475. https://doi.org/10.1016/S0169-5347(00)01971-6

Rees, H. C., B. C. Maddison, D. J. Middleditch, J. R. M. Patmore and K. C. Gough (2014). REVIEW: The detection of aquatic animal species using environmental DNA - a review of eDNA as a survey tool in ecology. 51(5): 1450-1459.

Rodgers, T. W., Xu, C. C. Y., Giacalone, J., Kapheim, K. M., Saltonstall, K., Vargas, M., Yu, D. W., Somervuo, P., McMillan, W. O., \& Jansen, P. A. (2017). Carrion fly-derived DNA metabarcoding is an effective tool for mammal surveys: Evidence from a known tropical mammal community. Molecular Ecology Resources, 17(6), e133-e145. 
Roveroa, F. Z., Duccio Berzid, Paul Meek (2013). Which camera trap type and how many do I need? A review of camera features and study designs for a range of wildlife research applications. Journal of Mammalogy.

Schnell, I. B., Sollmann, R., Calvignac-Spencer, S., Siddall, M. E., Yu, D. W., Wilting, A., \& Gilbert, M. T. P. (2015). iDNA from terrestrial haematophagous leeches as a wildlife surveying and monitoring tool - prospects, pitfalls and avenues to be developed. Frontiers in Zoology, 12(1), 1-14. https://doi.org/10.1186/s12983-015-0115-Z

Sonenshine, D. E., \& Roe, R. M. (2014). External and Internal Anatomy of Ticks. Biology of Ticks Vol. 1, 74-98.

Stroud, J. T., Bush, M. R., Ladd, M. C., Nowicki, R. J., Shantz, A. A., \& Sweatman, J. (2015). Is a community still a community? Reviewing definitions of key terms in community ecology. Ecology and Evolution, 5(21), 4757-4765. https://doi.org/10.1002/ece3.1651

Takken, W., \& Verhulst, N. O. (2013). Host Preferences of Blood-Feeding Mosquitoes. Annual Review of Entomology, 58(1), 433-453. https://doi.org/10.1146/annurev-ento-120811-153618

Waits, L. P., \& Pawtkau, D. (2005). Noninvasive Genetic Sampling Tools for Wildlife Biologists: a Review of Applications and Recommendations for Accurate Data Collection. Journal of Wildlife Management, 69(4), 1419-1433.

Walker, E.D. (1998) Geographic distribution of ticks (Acari: Ixodidae) in Michigan, with emphasis on Ixodes scapularis and Borrelia burgdorferi. Journal of Medical Entomology. 35(5): 872-882

Weiskopf, S. R., McCarthy, K. P., Tessler, M., Rahman, H. A., McCarthy, J. L., Hersch, R., Faisal, M. M., \& Siddall, M. E. (2018). Using terrestrial haematophagous leeches to enhance tropical biodiversity monitoring programmes in Bangladesh. Journal of Applied Ecology, 55(4), 2071-2081. https://doi.org/10.1111/1365-2664.13111

Wikel, S. K. (2018). Ticks and Tick-Borne Infections: Complex Ecology, Agents, and Host Interactions. Veterinary sciences, 5(2), 60. https://doi.org/10.3390/vetsci5020060

Williams, G. M., Gingrich, J. B. (2007). Comparison of light traps, gravid traps, and resting boxes for West Nile virus surveillance. Journal of Vector Ecology, $32(2), 285-91$.

Wood, C. M., Witham, J. W., \& Hunter, M. L. (2016). Climate-driven range shifts are stochastic processes at a local level: Two flying squirrel species in Maine. Ecosphere, 7(2), 1-9. https://doi.org/10.1002/ecs2.1240 


\section{Supplemental Material}

Supplemental Table 1. Metadata of all camera traps that were deployed during the 2019 field season in the Silvicultural Experiment for Enhancing Diversity (NHSEED) plots located in Baraga county, Michigan.

\begin{tabular}{|c|c|c|c|c|c|c|c|c|c|}
\hline $\begin{array}{l}\text { Station } \\
\text { Type }\end{array}$ & Station & Site & $\begin{array}{l}\text { utm } \\
\text { y }\end{array}$ & $\begin{array}{l}\text { utm } \\
\text { X }\end{array}$ & Setup_date & $\begin{array}{l}\text { Retrieval } \\
\text { date }\end{array}$ & Canopy & Understory & $\begin{array}{l}\text { Working } \\
\text { Trap } \\
\text { Nights }\end{array}$ \\
\hline Unbaited & $\begin{array}{l}\text { NHSEE } \\
\text { D_01 }\end{array}$ & 1 & $\begin{array}{l}387 \\
234\end{array}$ & $\begin{array}{r}516 \\
512 \\
1\end{array}$ & $7 / 13 / 2019$ & $8 / 21 / 2019$ & $\begin{array}{l}\text { Irregular } \\
\text { _Shelter } \\
\text { _Low }\end{array}$ & TipUp & 39 \\
\hline Unbaited & $\begin{array}{l}\text { NHSEE } \\
\text { D_02 }\end{array}$ & 2 & $\begin{array}{l}387 \\
265\end{array}$ & $\begin{array}{r}516 \\
492 \\
5\end{array}$ & $6 / 4 / 2019$ & $7 / 13 / 2019$ & $\begin{array}{l}\text { Irregular } \\
\text { _Shelter } \\
\text { _Low }\end{array}$ & Scar & 39 \\
\hline Unbaited & $\begin{array}{l}\text { NHSEE } \\
\text { D_03 }\end{array}$ & 3 & $\begin{array}{l}387 \\
204\end{array}$ & $\begin{array}{r}516 \\
502 \\
6\end{array}$ & $8 / 21 / 2019$ & $\begin{array}{r}10 / 19 / 201 \\
9\end{array}$ & $\begin{array}{l}\text { Irregular } \\
\text { _Shelter } \\
\text { _Low }\end{array}$ & Control & 59 \\
\hline Unbaited & $\begin{array}{l}\text { NHSEE } \\
\text { D_04 }\end{array}$ & 4 & $\begin{array}{l}387 \\
266\end{array}$ & $\begin{array}{r}516 \\
494 \\
3\end{array}$ & $6 / 4 / 2019$ & $7 / 13 / 2019$ & $\begin{array}{l}\text { Irregular } \\
\text { _Shelter } \\
\text { _High }\end{array}$ & Scar & 39 \\
\hline Unbaited & $\begin{array}{l}\text { NHSEE } \\
\text { D_05 }\end{array}$ & 5 & $\begin{array}{l}387 \\
253\end{array}$ & $\begin{array}{r}516 \\
488 \\
8\end{array}$ & $8 / 21 / 2019$ & $\begin{array}{r}10 / 19 / 201 \\
9\end{array}$ & $\begin{array}{l}\text { Irregular } \\
\text { _Shelter } \\
\text { _High }\end{array}$ & TipUp & 59 \\
\hline Unbaited & $\begin{array}{l}\text { NHSEE } \\
\text { D_06 }\end{array}$ & 6 & $\begin{array}{l}387 \\
179 \\
\end{array}$ & $\begin{array}{r}516 \\
490 \\
3\end{array}$ & $8 / 21 / 2019$ & $\begin{array}{r}10 / 19 / 201 \\
9\end{array}$ & $\begin{array}{l}\text { Irregular } \\
\text { _Shelter } \\
\text { _High }\end{array}$ & Control & 0 \\
\hline Unbaited & $\begin{array}{l}\text { NHSEE } \\
\text { D_07 }\end{array}$ & 7 & $\begin{array}{l}387 \\
132\end{array}$ & $\begin{array}{r}516 \\
442 \\
8\end{array}$ & $6 / 4 / 2019$ & $7 / 13 / 2019$ & $\begin{array}{l}\text { Shelter_ } \\
\text { Low }\end{array}$ & Scar & 6 \\
\hline Unbaited & $\begin{array}{l}\text { NHSEE } \\
\text { D_08 }\end{array}$ & 8 & $\begin{array}{l}387 \\
100\end{array}$ & $\begin{array}{r}516 \\
493 \\
1\end{array}$ & 7/13/2019 & $8 / 21 / 2019$ & $\begin{array}{l}\text { Shelter } \\
\text { Low }\end{array}$ & TipUp & 0 \\
\hline Unbaited & $\begin{array}{l}\text { NHSEE } \\
\text { D_09 }\end{array}$ & 9 & $\begin{array}{l}387 \\
048\end{array}$ & $\begin{array}{r}516 \\
494 \\
2\end{array}$ & $8 / 21 / 2019$ & $\begin{array}{r}10 / 19 / 201 \\
9\end{array}$ & $\begin{array}{l}\text { Shelter_ } \\
\text { Low }\end{array}$ & Control & 59 \\
\hline Unbaited & $\begin{array}{l}\text { NHSEE } \\
\text { D_10 }\end{array}$ & 10 & $\begin{array}{l}387 \\
027\end{array}$ & $\begin{array}{r}516 \\
494 \\
8\end{array}$ & $8 / 21 / 2019$ & $\begin{array}{r}10 / 19 / 201 \\
9\end{array}$ & Clearcut & Scar & 0 \\
\hline Unbaited & $\begin{array}{l}\text { NHSEE } \\
\text { D_11 }\end{array}$ & 11 & $\begin{array}{l}386 \\
970\end{array}$ & $\begin{array}{r}516 \\
495 \\
3\end{array}$ & $6 / 4 / 2019$ & $7 / 13 / 2019$ & Clearcut & TipUp & 39 \\
\hline Unbaited & $\begin{array}{l}\text { NHSEE } \\
\text { D_12 }\end{array}$ & 12 & $\begin{array}{l}386 \\
918\end{array}$ & $\begin{array}{r}516 \\
495 \\
4\end{array}$ & $6 / 4 / 2019$ & $7 / 13 / 2019$ & Clearcut & Control & 4 \\
\hline
\end{tabular}




\begin{tabular}{|c|c|c|c|c|c|c|c|c|c|}
\hline Unbaited & $\begin{array}{l}\text { NHSEE } \\
\text { D_13 }\end{array}$ & 13 & $\begin{array}{l}386 \\
873\end{array}$ & $\begin{array}{r}516 \\
494 \\
4\end{array}$ & $7 / 13 / 2019$ & $8 / 21 / 2019$ & $\begin{array}{l}\text { Shelter_ } \\
\text { High }\end{array}$ & Control & 39 \\
\hline Unbaited & $\begin{array}{l}\text { NHSEE } \\
\text { D_14 }\end{array}$ & 14 & $\begin{array}{l}386 \\
845\end{array}$ & $\begin{array}{r}516 \\
494 \\
9\end{array}$ & 8/21/2019 & $\begin{array}{r}10 / 19 / 201 \\
9\end{array}$ & $\begin{array}{l}\text { Shelter_ } \\
\text { High }\end{array}$ & Scar & 59 \\
\hline Unbaited & $\begin{array}{l}\text { NHSEE } \\
\text { D_15 }\end{array}$ & 15 & $\begin{array}{l}386 \\
781\end{array}$ & $\begin{array}{r}516 \\
495 \\
5\end{array}$ & $6 / 5 / 2019$ & $7 / 13 / 2019$ & $\begin{array}{l}\text { Shelter_ } \\
\text { High }\end{array}$ & TipUp & 38 \\
\hline Unbaited & $\begin{array}{l}\text { NHSEE } \\
\text { D_16 }\end{array}$ & 16 & $\begin{array}{l}386 \\
733\end{array}$ & $\begin{array}{r}516 \\
495 \\
8\end{array}$ & 8/21/2019 & $\begin{array}{r}10 / 19 / 201 \\
9\end{array}$ & $\begin{array}{l}\text { SingleTr } \\
\text { ee }\end{array}$ & TipUp & 0 \\
\hline Unbaited & $\begin{array}{l}\text { NHSEE } \\
\text { D_17 }\end{array}$ & 17 & $\begin{array}{l}386 \\
701\end{array}$ & $\begin{array}{r}516 \\
494 \\
4\end{array}$ & $6 / 4 / 2019$ & $7 / 13 / 2019$ & $\begin{array}{l}\text { SingleTr } \\
\text { ee }\end{array}$ & Scar & 39 \\
\hline Unbaited & $\begin{array}{l}\text { NHSEE } \\
\text { D_18 }\end{array}$ & 18 & $\begin{array}{l}386 \\
655\end{array}$ & $\begin{array}{r}516 \\
497 \\
7\end{array}$ & $7 / 16 / 2019$ & $8 / 21 / 2019$ & $\begin{array}{l}\text { SingleTr } \\
\text { ee }\end{array}$ & Control & 1 \\
\hline Unbaited & $\begin{array}{l}\text { NHSEE } \\
\text { D_19 }\end{array}$ & 19 & $\begin{array}{l}386 \\
607\end{array}$ & $\begin{array}{r}516 \\
495 \\
6\end{array}$ & $7 / 13 / 2019$ & $8 / 20 / 2019$ & $\begin{array}{l}\text { Shelter_ } \\
\text { High }\end{array}$ & TipUp & 0 \\
\hline Unbaited & $\begin{array}{l}\text { NHSEE } \\
\text { D_20 }\end{array}$ & 20 & $\begin{array}{l}386 \\
579\end{array}$ & $\begin{array}{r}516 \\
507 \\
2 \\
\end{array}$ & $6 / 4 / 2019$ & $7 / 13 / 2019$ & $\begin{array}{l}\text { Shelter_ } \\
\text { High }\end{array}$ & Control & 13 \\
\hline Unbaited & $\begin{array}{l}\text { NHSEE } \\
\text { D_21 }\end{array}$ & 21 & $\begin{array}{l}386 \\
532\end{array}$ & $\begin{array}{r}516 \\
495 \\
0\end{array}$ & $6 / 5 / 2019$ & $7 / 13 / 2019$ & $\begin{array}{l}\text { Shelter_ } \\
\text { High }\end{array}$ & Scar & 38 \\
\hline Unbaited & $\begin{array}{l}\text { NHSEE } \\
\text { D_22 }\end{array}$ & 22 & $\begin{array}{l}386 \\
420\end{array}$ & \begin{tabular}{r|}
516 \\
491 \\
8
\end{tabular} & $7 / 13 / 2019$ & $8 / 21 / 2019$ & $\begin{array}{l}\text { Irregular } \\
\text { _Shelter } \\
\text { _High }\end{array}$ & TipUp & 39 \\
\hline Unbaited & $\begin{array}{l}\text { NHSEE } \\
\text { D_23 }\end{array}$ & 23 & $\begin{array}{l}387 \\
240\end{array}$ & $\begin{array}{r}516 \\
400 \\
4 \\
\end{array}$ & $7 / 13 / 2019$ & $8 / 21 / 2019$ & $\begin{array}{l}\text { Shelter_ } \\
\text { High }\end{array}$ & Control & 0 \\
\hline Unbaited & $\begin{array}{l}\text { NHSEE } \\
\text { D_24 }\end{array}$ & 24 & $\begin{array}{l}387 \\
163\end{array}$ & $\begin{array}{r}516 \\
478 \\
4\end{array}$ & $6 / 5 / 2019$ & $7 / 13 / 2019$ & $\begin{array}{l}\text { Shelter_ } \\
\text { High }\end{array}$ & TipUp & 21 \\
\hline Unbaited & $\begin{array}{l}\text { NHSEE } \\
\text { D_25 }\end{array}$ & 25 & $\begin{array}{l}387 \\
097\end{array}$ & $\begin{array}{r}516 \\
482 \\
0\end{array}$ & 8/21/2019 & $\begin{array}{r}10 / 19 / 201 \\
9\end{array}$ & $\begin{array}{l}\text { Shelter } \\
\text { High }\end{array}$ & Scar & 59 \\
\hline Unbaited & $\begin{array}{l}\text { NHSEE } \\
\text { D_26 }\end{array}$ & 26 & $\begin{array}{l}386 \\
811\end{array}$ & $\begin{array}{r}516 \\
483 \\
0 \\
\end{array}$ & $6 / 5 / 2019$ & $7 / 13 / 2019$ & $\begin{array}{l}\text { Irregular } \\
\text { _Shelter } \\
\text { _High }\end{array}$ & Control & 3 \\
\hline Unbaited & $\begin{array}{l}\text { NHSEE } \\
\text { D_27 }\end{array}$ & 27 & $\begin{array}{l}386 \\
654\end{array}$ & $\begin{array}{r}516 \\
485 \\
5\end{array}$ & $8 / 21 / 2019$ & $\begin{array}{r}10 / 19 / 201 \\
9\end{array}$ & $\begin{array}{l}\text { Irregular } \\
\text { _Shelter } \\
\text { _High }\end{array}$ & TipUp & 59 \\
\hline
\end{tabular}




\begin{tabular}{|c|c|c|c|c|c|c|c|c|c|}
\hline Unbaited & $\begin{array}{l}\text { NHSEE } \\
\text { D_28 }\end{array}$ & 28 & $\begin{array}{l}386 \\
585\end{array}$ & $\begin{array}{r}516 \\
484 \\
5\end{array}$ & $7 / 13 / 2019$ & $8 / 21 / 2019$ & $\begin{array}{l}\text { Irregular } \\
\text { _Shelter } \\
\text { _Low }\end{array}$ & Scar & 39 \\
\hline Unbaited & $\begin{array}{l}\text { NHSEE } \\
\text { D_29 }\end{array}$ & 29 & $\begin{array}{l}386 \\
549\end{array}$ & $\begin{array}{r}516 \\
484 \\
1\end{array}$ & $8 / 21 / 2019$ & $\begin{array}{r}10 / 19 / 201 \\
9\end{array}$ & $\begin{array}{l}\text { Irregular } \\
\text { _Shelter } \\
\text { _Low }\end{array}$ & TipUp & 45 \\
\hline Unbaited & $\begin{array}{l}\text { NHSEE } \\
\text { D_30 }\end{array}$ & 30 & $\begin{array}{l}386 \\
460\end{array}$ & $\begin{array}{r}516 \\
486 \\
4\end{array}$ & $8 / 21 / 2019$ & $\begin{array}{r}10 / 19 / 201 \\
9\end{array}$ & $\begin{array}{l}\text { Irregular } \\
\text { _Shelter } \\
\text { _High }\end{array}$ & Control & 0 \\
\hline Unbaited & $\begin{array}{l}\text { NHSEE } \\
\text { D_31 }\end{array}$ & 31 & $\begin{array}{l}386 \\
362\end{array}$ & $\begin{array}{r}516 \\
480 \\
1\end{array}$ & 7/13/2019 & $8 / 21 / 2019$ & $\begin{array}{l}\text { Irregular } \\
\text { _Shelter } \\
\text { _High }\end{array}$ & Scar & 39 \\
\hline Unbaited & $\begin{array}{l}\text { NHSEE } \\
\text { D_32 }\end{array}$ & 32 & $\begin{array}{l}387 \\
236\end{array}$ & $\begin{array}{r}516 \\
470 \\
9\end{array}$ & $7 / 13 / 2019$ & $8 / 21 / 2019$ & Clearcut & Scar & 39 \\
\hline Unbaited & $\begin{array}{l}\text { NHSEE } \\
\text { D_33 }\end{array}$ & 33 & $\begin{array}{l}387 \\
158\end{array}$ & $\begin{array}{r}516 \\
469 \\
4\end{array}$ & $6 / 5 / 2019$ & 7/13/2019 & Clearcut & Control & 28 \\
\hline Unbaited & $\begin{array}{l}\text { NHSEE } \\
\text { D_34 }\end{array}$ & 34 & $\begin{array}{l}387 \\
085\end{array}$ & $\begin{array}{r}516 \\
469 \\
5\end{array}$ & $6 / 5 / 2019$ & $7 / 13 / 2019$ & Clearcut & TipUp & 36 \\
\hline Unbaited & $\begin{array}{l}\text { NHSEE } \\
\text { D_35 }\end{array}$ & 35 & $\begin{array}{l}386 \\
961\end{array}$ & $\begin{array}{r}516 \\
466 \\
3\end{array}$ & $6 / 5 / 2019$ & $7 / 13 / 2019$ & $\begin{array}{l}\text { Shelter_ } \\
\text { Low }\end{array}$ & Control & 8 \\
\hline Unbaited & $\begin{array}{l}\text { NHSEE } \\
\text { D_36 }\end{array}$ & 36 & $\begin{array}{l}386 \\
879\end{array}$ & $\begin{array}{r}516 \\
468 \\
5\end{array}$ & $8 / 20 / 2019$ & $\begin{array}{r}10 / 19 / 201 \\
9\end{array}$ & $\begin{array}{l}\text { Shelter_ } \\
\text { Low }\end{array}$ & TipUp & 0 \\
\hline Unbaited & $\begin{array}{l}\text { NHSEE } \\
\text { D_37 }\end{array}$ & 37 & $\begin{array}{l}386 \\
815\end{array}$ & $\begin{array}{r}516 \\
466 \\
2\end{array}$ & $6 / 5 / 2019$ & 7/13/2019 & $\begin{array}{l}\text { Shelter_ } \\
\text { Low }\end{array}$ & Scar & 38 \\
\hline Unbaited & $\begin{array}{l}\text { NHSEE } \\
\text { D_38 }\end{array}$ & 38 & $\begin{array}{l}386 \\
731\end{array}$ & $\begin{array}{r}516 \\
473 \\
4\end{array}$ & $8 / 20 / 2019$ & $\begin{array}{r}10 / 19 / 201 \\
9\end{array}$ & $\begin{array}{l}\text { Irregular } \\
\text { _Shelter } \\
\text { _High }\end{array}$ & Scar & 0 \\
\hline Unbaited & $\begin{array}{l}\text { NHSEE } \\
\text { D_39 }\end{array}$ & 39 & $\begin{array}{l}386 \\
737\end{array}$ & $\begin{array}{r}516 \\
469 \\
8\end{array}$ & $7 / 13 / 2019$ & $8 / 20 / 2019$ & $\begin{array}{l}\text { Irregular } \\
\text { _Shelter } \\
\text { _Low }\end{array}$ & TipUp & 38 \\
\hline Unbaited & $\begin{array}{l}\text { NHSEE } \\
\text { D_40 }\end{array}$ & 40 & $\begin{array}{l}386 \\
541\end{array}$ & $\begin{array}{r}516 \\
474 \\
3\end{array}$ & $6 / 5 / 2019$ & $6 / 28 / 2019$ & $\begin{array}{l}\text { Irregular } \\
\text { _Shelter } \\
\text { _Low }\end{array}$ & Control & 1 \\
\hline Unbaited & $\begin{array}{l}\text { NHSEE } \\
\text { D_41 }\end{array}$ & 41 & $\begin{array}{l}386 \\
868\end{array}$ & $\begin{array}{r}516 \\
459 \\
4\end{array}$ & $6 / 21 / 2019$ & $7 / 13 / 2019$ & $\begin{array}{l}\text { Shelter_ } \\
\text { Low }\end{array}$ & Control & 7 \\
\hline Unbaited & $\begin{array}{l}\text { NHSEE } \\
\text { D_42 }\end{array}$ & 42 & $\begin{array}{l}386 \\
818\end{array}$ & $\begin{array}{r}516 \\
451 \\
3\end{array}$ & $7 / 13 / 2019$ & $8 / 20 / 2019$ & $\begin{array}{l}\text { Shelter_ } \\
\text { Low }\end{array}$ & TipUp & 38 \\
\hline
\end{tabular}




\begin{tabular}{|c|c|c|c|c|c|c|c|c|c|}
\hline Unbaited & $\begin{array}{l}\text { NHSEE } \\
\text { D_43 }\end{array}$ & 43 & $\begin{array}{l}386 \\
786\end{array}$ & $\begin{array}{r}516 \\
442 \\
3\end{array}$ & $7 / 13 / 2019$ & $8 / 20 / 2019$ & $\begin{array}{l}\text { Shelter_ } \\
\text { Low }\end{array}$ & Scar & 0 \\
\hline Unbaited & $\begin{array}{l}\text { NHSEE } \\
\text { D_44 }\end{array}$ & 44 & $\begin{array}{l}386 \\
754\end{array}$ & $\begin{array}{r}516 \\
460 \\
8\end{array}$ & 6/5/2019 & 7/13/2019 & $\begin{array}{l}\text { Irregular } \\
\text { _Shelter } \\
\text { _Low }\end{array}$ & Control & 0 \\
\hline Unbaited & $\begin{array}{l}\text { NHSEE } \\
\text { D_45 }\end{array}$ & 45 & $\begin{array}{l}386 \\
735\end{array}$ & $\begin{array}{r}516 \\
451 \\
4\end{array}$ & 7/13/2019 & $8 / 20 / 2019$ & $\begin{array}{l}\text { Irregular } \\
\text { _Shelter } \\
\text { _Low }\end{array}$ & Scar & 38 \\
\hline Unbaited & $\begin{array}{l}\text { NHSEE } \\
\text { D_46 }\end{array}$ & 46 & $\begin{array}{l}386 \\
691\end{array}$ & $\begin{array}{r}516 \\
437 \\
1\end{array}$ & 7/13/2019 & 8/20/2019 & Clearcut & Scar & 38 \\
\hline Unbaited & $\begin{array}{l}\text { NHSEE } \\
\text { D_49 }\end{array}$ & 49 & $\begin{array}{l}387 \\
050 \\
\end{array}$ & $\begin{array}{r}516 \\
459 \\
5\end{array}$ & $8 / 20 / 2019$ & $\begin{array}{r}10 / 18 / 201 \\
9 \\
\end{array}$ & $\begin{array}{l}\text { SingleTr } \\
\text { ee }\end{array}$ & Scar & 59 \\
\hline Unbaited & $\begin{array}{l}\text { NHSEE } \\
\text { D_50 }\end{array}$ & 50 & $\begin{array}{l}387 \\
033\end{array}$ & $\begin{array}{r}516 \\
156 \\
9\end{array}$ & 7/13/2019 & $8 / 21 / 2019$ & $\begin{array}{l}\text { SingleTr } \\
\text { ee }\end{array}$ & Scar & 39 \\
\hline Unbaited & $\begin{array}{l}\text { NHSEE } \\
\text { D_51 }\end{array}$ & 51 & $\begin{array}{l}386 \\
985\end{array}$ & $\begin{array}{r}516 \\
450 \\
2\end{array}$ & $6 / 5 / 2019$ & 7/13/2019 & $\begin{array}{l}\text { SingleTr } \\
\text { ee }\end{array}$ & TipUp & 38 \\
\hline Unbaited & $\begin{array}{l}\text { NHSEE } \\
\text { D_52 }\end{array}$ & 52 & $\begin{array}{l}386 \\
961\end{array}$ & $\begin{array}{r}516 \\
446 \\
4\end{array}$ & $7 / 13 / 2019$ & $8 / 20 / 2019$ & $\begin{array}{l}\text { SingleTr } \\
\text { ee }\end{array}$ & Control & 0 \\
\hline Unbaited & $\begin{array}{l}\text { NHSEE } \\
\text { D_53 }\end{array}$ & 53 & $\begin{array}{l}386 \\
897\end{array}$ & $\begin{array}{r}516 \\
439 \\
8\end{array}$ & $7 / 13 / 2019$ & $8 / 20 / 2019$ & Clearcut & Control & 38 \\
\hline Unbaited & $\begin{array}{l}\text { NHSEE } \\
\text { D_54 }\end{array}$ & 54 & $\begin{array}{l}386 \\
796\end{array}$ & $\begin{array}{r}516 \\
435 \\
2\end{array}$ & $7 / 16 / 2019$ & $8 / 20 / 2019$ & Clearcut & TipUp & 35 \\
\hline Baited & FSP_01 & 1 & $\begin{array}{l}387 \\
238\end{array}$ & $\begin{array}{r}516 \\
512 \\
0\end{array}$ & 9/5/2019 & 9/19/2019 & $\begin{array}{l}\text { Irregular } \\
\text { _Shelter } \\
\text { _Low }\end{array}$ & TipUp & 14 \\
\hline Baited & FSP_02 & 2 & $\begin{array}{l}387 \\
270\end{array}$ & $\begin{array}{r}516 \\
504 \\
0\end{array}$ & 9/19/2019 & $9 / 26 / 2019$ & $\begin{array}{l}\text { Irregular } \\
\text { _Shelter } \\
\text { _Low }\end{array}$ & Scar & 7 \\
\hline Baited & FSP_03 & 3 & $\begin{array}{l}387 \\
197\end{array}$ & $\begin{array}{r}516 \\
502 \\
8\end{array}$ & $9 / 5 / 2019$ & $\begin{array}{r}10 / 24 / 201 \\
9\end{array}$ & $\begin{array}{l}\text { Irregular } \\
\text { _Shelter } \\
\text { _Low }\end{array}$ & Control & 49 \\
\hline Baited & FSP_04 & 4 & $\begin{array}{l}387 \\
265\end{array}$ & $\begin{array}{r}516 \\
495 \\
1\end{array}$ & $\begin{array}{r}10 / 10 / 201 \\
9\end{array}$ & $\begin{array}{r}10 / 24 / 201 \\
9 \\
\end{array}$ & $\begin{array}{l}\text { Irregular } \\
\text { _Shelter } \\
\text { _High }\end{array}$ & Scar & 14 \\
\hline Baited & FSP_05 & 5 & $\begin{array}{l}387 \\
265\end{array}$ & $\begin{array}{r}516 \\
495 \\
1\end{array}$ & $\begin{array}{r}10 / 10 / 201 \\
9\end{array}$ & $\begin{array}{r}10 / 24 / 201 \\
9\end{array}$ & $\begin{array}{l}\text { Irregular } \\
\text { _Shelter } \\
\text { _High }\end{array}$ & TipUp & 14 \\
\hline
\end{tabular}




\begin{tabular}{|c|c|c|c|c|c|c|c|c|c|}
\hline Baited & FSP_06 & 6 & \begin{tabular}{|l|}
387 \\
182
\end{tabular} & $\begin{array}{r}516 \\
492 \\
0\end{array}$ & 9/26/2019 & $\begin{array}{r}10 / 10 / 201 \\
9\end{array}$ & $\begin{array}{l}\text { Irregular } \\
\text { _Shelter } \\
\text { _High }\end{array}$ & Control & 14 \\
\hline Baited & FSP_07 & 7 & \begin{tabular}{|l|}
387 \\
133
\end{tabular} & $\begin{array}{r}516 \\
492 \\
3\end{array}$ & $\begin{array}{r}10 / 10 / 201 \\
9\end{array}$ & $\begin{array}{r}10 / 24 / 201 \\
9\end{array}$ & $\begin{array}{l}\text { Shelter_ } \\
\text { Low }\end{array}$ & Scar & 14 \\
\hline Baited & FSP_08 & 8 & \begin{tabular}{|l|}
387 \\
092
\end{tabular} & $\begin{array}{r}516 \\
493 \\
1\end{array}$ & $\begin{array}{r}10 / 24 / 201 \\
9\end{array}$ & $\begin{array}{r}10 / 31 / 201 \\
9\end{array}$ & $\begin{array}{l}\text { Shelter_ } \\
\text { Low }\end{array}$ & TipUp & 7 \\
\hline Baited & FSP_09 & 9 & \begin{tabular}{|l|}
387 \\
056
\end{tabular} & $\begin{array}{r}516 \\
493 \\
1\end{array}$ & $9 / 5 / 2019$ & 9/19/2019 & $\begin{array}{l}\text { Shelter_ } \\
\text { Low }\end{array}$ & Control & 14 \\
\hline Baited & FSP_10 & 10 & $\begin{array}{l}387 \\
011\end{array}$ & $\begin{array}{r}516 \\
493 \\
2\end{array}$ & $\begin{array}{r}10 / 24 / 201 \\
9\end{array}$ & $\begin{array}{r}10 / 31 / 201 \\
9\end{array}$ & Clearcut & Scar & 7 \\
\hline Baited & FSP_11 & 11 & $\begin{array}{l}386 \\
964\end{array}$ & $\begin{array}{r}516 \\
494 \\
3\end{array}$ & $9 / 19 / 2019$ & 9/26/2019 & Clearcut & TipUp & 7 \\
\hline Baited & FSP_12 & 12 & \begin{tabular}{|l|}
386 \\
919
\end{tabular} & $\begin{array}{r}516 \\
494 \\
7\end{array}$ & 9/19/2019 & 9/26/2019 & Clearcut & Control & 7 \\
\hline Baited & FSP_13 & 13 & $\begin{array}{l}386 \\
880\end{array}$ & $\begin{array}{r}516 \\
495 \\
0\end{array}$ & $\begin{array}{r}10 / 10 / 201 \\
9\end{array}$ & $\begin{array}{r}10 / 24 / 201 \\
9\end{array}$ & $\begin{array}{l}\text { Shelter_ } \\
\text { High }\end{array}$ & Control & 14 \\
\hline Baited & FSP_14 & 14 & \begin{tabular}{|l|}
386 \\
831
\end{tabular} & $\begin{array}{r}516 \\
495 \\
5\end{array}$ & 9/5/2019 & 9/19/2019 & $\begin{array}{l}\text { Shelter_ } \\
\text { High }\end{array}$ & Scar & 14 \\
\hline Baited & FSP_15 & 15 & $\begin{array}{l}386 \\
781\end{array}$ & $\begin{array}{r}516 \\
495 \\
5\end{array}$ & $9 / 19 / 2019$ & 9/26/2019 & $\begin{array}{l}\text { Shelter_ } \\
\text { High }\end{array}$ & TipUp & 7 \\
\hline Baited & FSP_16 & 16 & \begin{tabular}{|l|}
386 \\
741
\end{tabular} & $\begin{array}{r}516 \\
495 \\
6\end{array}$ & 9/26/2019 & $\begin{array}{r}10 / 31 / 201 \\
9\end{array}$ & $\begin{array}{l}\text { SingleTr } \\
\text { ee }\end{array}$ & TipUp & 21 \\
\hline Baited & FSP_17 & 17 & $\begin{array}{l}386 \\
693\end{array}$ & $\begin{array}{r}516 \\
495 \\
8\end{array}$ & $9 / 5 / 2019$ & 9/19/2019 & $\begin{array}{l}\text { SingleTr } \\
\text { ee }\end{array}$ & Scar & 0 \\
\hline Baited & FSP_18 & 18 & $\begin{array}{l}386 \\
644\end{array}$ & $\begin{array}{r}516 \\
496 \\
7\end{array}$ & $8 / 21 / 2019$ & 9/5/2019 & $\begin{array}{l}\text { SingleTr } \\
\text { ee }\end{array}$ & Control & 15 \\
\hline Baited & FSP_19 & 19 & $\begin{array}{l}386 \\
600\end{array}$ & $\begin{array}{r}516 \\
474 \\
9\end{array}$ & $8 / 21 / 2019$ & 9/5/2019 & $\begin{array}{l}\text { Shelter } \\
\text { High }\end{array}$ & TipUp & 15 \\
\hline Baited & FSP_20 & 20 & $\begin{array}{l}386 \\
577\end{array}$ & $\begin{array}{r}516 \\
504 \\
1\end{array}$ & 9/26/2019 & $\begin{array}{r}10 / 10 / 201 \\
9\end{array}$ & $\begin{array}{l}\text { Shelter_ } \\
\text { High }\end{array}$ & Control & 14 \\
\hline
\end{tabular}




\begin{tabular}{|c|c|c|c|c|c|c|c|c|c|}
\hline Baited & FSP_21 & 21 & $\begin{array}{l}386 \\
532\end{array}$ & $\begin{array}{r}516 \\
495 \\
0\end{array}$ & $\begin{array}{r}10 / 10 / 201 \\
9\end{array}$ & $\begin{array}{r}10 / 24 / 201 \\
9\end{array}$ & $\begin{array}{l}\text { Shelter_ } \\
\text { High }\end{array}$ & Scar & 14 \\
\hline Baited & FSP_22 & 22 & $\begin{array}{l}386 \\
434\end{array}$ & $\begin{array}{r}516 \\
491 \\
3\end{array}$ & $\begin{array}{r}10 / 10 / 201 \\
9\end{array}$ & $\begin{array}{r}10 / 24 / 201 \\
9\end{array}$ & $\begin{array}{l}\text { Irregular } \\
\text { _Shelter } \\
\text { _High }\end{array}$ & TipUp & 14 \\
\hline Baited & FSP_23 & 23 & $\begin{array}{l}387 \\
240\end{array}$ & $\begin{array}{r}516 \\
477 \\
6\end{array}$ & $9 / 5 / 2019$ & $9 / 19 / 2019$ & $\begin{array}{l}\text { Shelter_ } \\
\text { High }\end{array}$ & Control & 14 \\
\hline Baited & FSP_24 & 24 & $\begin{array}{l}387 \\
163\end{array}$ & $\begin{array}{r}516 \\
478 \\
4\end{array}$ & 9/5/2019 & 9/19/2019 & $\begin{array}{l}\text { Shelter_ } \\
\text { High }\end{array}$ & TipUp & 14 \\
\hline Baited & FSP_25 & 25 & $\begin{array}{l}387 \\
094 \\
\end{array}$ & $\begin{array}{r}516 \\
479 \\
5\end{array}$ & $\begin{array}{r}10 / 10 / 201 \\
9 \\
\end{array}$ & $\begin{array}{r}10 / 24 / 201 \\
9 \\
\end{array}$ & $\begin{array}{l}\text { Shelter_ } \\
\text { High }\end{array}$ & Scar & 14 \\
\hline Baited & FSP_27 & 27 & $\begin{array}{l}386 \\
687\end{array}$ & $\begin{array}{r}516 \\
484 \\
3\end{array}$ & 9/5/2019 & 9/19/2019 & $\begin{array}{l}\text { Irregular } \\
\text { _Shelter } \\
\text { _High }\end{array}$ & TipUp & 14 \\
\hline Baited & FSP_26 & 26 & $\begin{array}{l}386 \\
811\end{array}$ & $\begin{array}{r}516 \\
483 \\
0\end{array}$ & $8 / 21 / 2019$ & 9/5/2019 & $\begin{array}{l}\text { Irregular } \\
\text { _Shelter } \\
\text { _High }\end{array}$ & Control & 15 \\
\hline Baited & FSP_28 & 28 & $\begin{array}{l}386 \\
596\end{array}$ & $\begin{array}{r}516 \\
482 \\
9\end{array}$ & $8 / 21 / 2019$ & $9 / 5 / 2019$ & $\begin{array}{l}\text { Irregular } \\
\text { _Shelter } \\
\text { _Low }\end{array}$ & Scar & 0 \\
\hline Baited & FSP_29 & 29 & $\begin{array}{l}386 \\
534\end{array}$ & $\begin{array}{r}516 \\
483 \\
3\end{array}$ & $9 / 19 / 2019$ & $9 / 26 / 2019$ & $\begin{array}{l}\text { Irregular } \\
\text { _Shelter } \\
\text { _Low }\end{array}$ & TipUp & 7 \\
\hline Baited & FSP_30 & 30 & $\begin{array}{l}386 \\
471\end{array}$ & $\begin{array}{r}516 \\
485 \\
3\end{array}$ & $\begin{array}{r}10 / 10 / 201 \\
9 \\
\end{array}$ & $\begin{array}{r}10 / 24 / 201 \\
9 \\
\end{array}$ & $\begin{array}{l}\text { Irregular } \\
\text { _Shelter } \\
\text { _High }\end{array}$ & Control & 14 \\
\hline Baited & FSP_31 & 31 & $\begin{array}{l}386 \\
363\end{array}$ & $\begin{array}{r}516 \\
481 \\
6\end{array}$ & 9/19/2019 & 9/26/2019 & $\begin{array}{l}\text { Irregular } \\
\text { _Shelter } \\
\text { _High }\end{array}$ & Scar & 7 \\
\hline Baited & FSP_32 & 32 & $\begin{array}{l}387 \\
237\end{array}$ & $\begin{array}{r}516 \\
469 \\
8\end{array}$ & 9/26/2019 & $\begin{array}{r}10 / 10 / 201 \\
9\end{array}$ & Clearcut & Scar & 1 \\
\hline Baited & FSP_33 & 33 & $\begin{array}{l}387 \\
158\end{array}$ & $\begin{array}{r}516 \\
469 \\
4\end{array}$ & $8 / 21 / 2019$ & $9 / 5 / 2019$ & Clearcut & Control & 15 \\
\hline Baited & FSP_34 & 34 & $\begin{array}{l}387 \\
085\end{array}$ & $\begin{array}{r}516 \\
469 \\
5\end{array}$ & 9/26/2019 & $\begin{array}{r}10 / 10 / 201 \\
9\end{array}$ & Clearcut & TipUp & 14 \\
\hline Baited & FSP_35 & 35 & $\begin{array}{l}386 \\
961\end{array}$ & $\begin{array}{r}516 \\
466 \\
3\end{array}$ & $8 / 21 / 2019$ & $9 / 5 / 2019$ & $\begin{array}{l}\text { Shelter_ } \\
\text { Low }\end{array}$ & Control & 15 \\
\hline
\end{tabular}




\begin{tabular}{|c|c|c|c|c|c|c|c|c|c|}
\hline Baited & FSP_36 & 36 & $\begin{array}{l}386 \\
890\end{array}$ & $\begin{array}{r}516 \\
469 \\
0\end{array}$ & $\begin{array}{r}10 / 24 / 201 \\
9\end{array}$ & $\begin{array}{r}10 / 31 / 201 \\
9\end{array}$ & $\begin{array}{l}\text { Shelter_ } \\
\text { Low }\end{array}$ & TipUp & 7 \\
\hline Baited & FSP_37 & 37 & $\begin{array}{l}386 \\
815\end{array}$ & $\begin{array}{r}516 \\
466 \\
2\end{array}$ & $\begin{array}{r}10 / 24 / 201 \\
9\end{array}$ & $\begin{array}{r}10 / 31 / 201 \\
9\end{array}$ & $\begin{array}{l}\text { Shelter_ } \\
\text { Low }\end{array}$ & Scar & 7 \\
\hline Baited & FSP_38 & 38 & $\begin{array}{l}386 \\
721\end{array}$ & $\begin{array}{r}516 \\
474 \\
9\end{array}$ & $8 / 21 / 2019$ & 9/5/2019 & $\begin{array}{l}\text { Irregular } \\
\text { _Shelter } \\
\text { _High }\end{array}$ & Scar & 15 \\
\hline Baited & FSP_39 & 39 & $\begin{array}{l}386 \\
739\end{array}$ & $\begin{array}{r}516 \\
468 \\
2\end{array}$ & $\begin{array}{r}10 / 24 / 201 \\
9\end{array}$ & $\begin{array}{r}10 / 31 / 201 \\
9\end{array}$ & $\begin{array}{l}\text { Irregular } \\
\text { _Shelter } \\
\text { _Low }\end{array}$ & TipUp & 7 \\
\hline Baited & FSP_40 & 40 & $\begin{array}{l}386 \\
541\end{array}$ & $\begin{array}{r}516 \\
474 \\
3\end{array}$ & $8 / 21 / 2019$ & 9/5/2019 & $\begin{array}{l}\text { Irregular } \\
\text { _Shelter } \\
\text { _Low }\end{array}$ & Control & 15 \\
\hline Baited & FSP_41 & 41 & $\begin{array}{l}386 \\
864\end{array}$ & $\begin{array}{r}516 \\
457 \\
8\end{array}$ & 9/26/2019 & $\begin{array}{r}10 / 10 / 201 \\
9\end{array}$ & $\begin{array}{l}\text { Shelter_ } \\
\text { Low }\end{array}$ & Control & 14 \\
\hline Baited & FSP_42 & 42 & $\begin{array}{l}386 \\
837\end{array}$ & $\begin{array}{r}516 \\
450 \\
5\end{array}$ & 9/26/2019 & $\begin{array}{r}10 / 10 / 201 \\
9\end{array}$ & $\begin{array}{l}\text { Shelter_ } \\
\text { Low }\end{array}$ & TipUp & 0 \\
\hline Baited & FSP_43 & 43 & $\begin{array}{l}386 \\
786\end{array}$ & $\begin{array}{r}516 \\
442 \\
3\end{array}$ & $\begin{array}{r}10 / 24 / 201 \\
9\end{array}$ & $\begin{array}{r}10 / 31 / 201 \\
9\end{array}$ & $\begin{array}{l}\text { Shelter_ } \\
\text { Low }\end{array}$ & Scar & 7 \\
\hline Baited & FSP_44 & 44 & $\begin{array}{l}386 \\
745\end{array}$ & $\begin{array}{r}516 \\
458 \\
6\end{array}$ & 9/19/2019 & $9 / 26 / 2019$ & $\begin{array}{l}\text { Irregular } \\
\text { _Shelter } \\
\text { _Low }\end{array}$ & Control & 7 \\
\hline Baited & FSP_45 & 45 & $\begin{array}{l}386 \\
720\end{array}$ & $\begin{array}{r}516 \\
449 \\
8\end{array}$ & $9 / 5 / 2019$ & 9/19/2019 & $\begin{array}{l}\text { Irregular } \\
\text { _Shelter } \\
\text { _Low }\end{array}$ & Scar & 14 \\
\hline Baited & FSP_46 & 46 & $\begin{array}{l}386 \\
690\end{array}$ & $\begin{array}{r}516 \\
435 \\
5\end{array}$ & $9 / 19 / 2019$ & $9 / 26 / 2019$ & Clearcut & Scar & 7 \\
\hline Baited & FSP_47 & 47 & $\begin{array}{l}387 \\
209\end{array}$ & $\begin{array}{r}516 \\
464 \\
0\end{array}$ & 9/26/2019 & $\begin{array}{r}10 / 10 / 201 \\
9\end{array}$ & $\begin{array}{l}\text { SingleTr } \\
\text { ee }\end{array}$ & Control & 0 \\
\hline Baited & FSP_48 & 48 & $\begin{array}{l}387 \\
108\end{array}$ & $\begin{array}{r}516 \\
457 \\
8 \\
\end{array}$ & 9/19/2019 & $9 / 26 / 2019$ & $\begin{array}{l}\text { SingleTr } \\
\text { ee }\end{array}$ & TipUp & 7 \\
\hline Baited & FSP_49 & 49 & $\begin{array}{l}387 \\
057\end{array}$ & $\begin{array}{r}516 \\
458 \\
4 \\
\end{array}$ & $8 / 21 / 2019$ & $9 / 5 / 2019$ & $\begin{array}{l}\text { SingleTr } \\
\text { ee }\end{array}$ & Scar & 15 \\
\hline Baited & FSP_50 & 50 & $\begin{array}{l}387 \\
015\end{array}$ & $\begin{array}{r}516 \\
454 \\
3\end{array}$ & $9 / 19 / 2019$ & 9/26/2019 & $\begin{array}{l}\text { SingleTr } \\
\text { ee }\end{array}$ & Scar & 7 \\
\hline
\end{tabular}




\begin{tabular}{|c|c|c|c|c|c|c|c|c|c|}
\hline Baited & FSP_51 & 51 & $\begin{array}{l}386 \\
985\end{array}$ & $\begin{array}{r}516 \\
450 \\
2\end{array}$ & $9 / 26 / 2019$ & $\begin{array}{r}10 / 10 / 201 \\
9\end{array}$ & $\begin{array}{l}\text { SingleTr } \\
\text { ee }\end{array}$ & TipUp & 14 \\
\hline Baited & FSP_52 & 52 & $\begin{array}{l}386 \\
950\end{array}$ & $\begin{array}{r}516 \\
447 \\
6\end{array}$ & 9/5/2019 & 9/19/2019 & $\begin{array}{l}\text { SingleTr } \\
\text { ee }\end{array}$ & Control & 14 \\
\hline Baited & FSP_53 & 53 & $\begin{array}{l}386 \\
897\end{array}$ & $\begin{array}{r}516 \\
439 \\
8\end{array}$ & 9/26/2019 & $\begin{array}{r}10 / 10 / 201 \\
9\end{array}$ & Clearcut & Control & 14 \\
\hline Baited & FSP_54 & 54 & $\begin{array}{l}386 \\
813\end{array}$ & $\begin{array}{r}516 \\
434 \\
6\end{array}$ & $8 / 21 / 2019$ & $9 / 5 / 2019$ & Clearcut & TipUp & 15 \\
\hline
\end{tabular}


Supplemental Table 2. Working camera nights of all cameras deployed by silviculture canopy treatment in Silvicultural Experiment to Enhance Diversity (NHSEED) plots located in Baraga county, Michigan.

\begin{tabular}{|l|c|}
\hline Canopy Treatments & Working Trap Nights \\
\hline Clearcut & 583 \\
\hline Shelter_High & 1196 \\
\hline Shelter_Low & 1201 \\
\hline SingleTree & 341 \\
\hline
\end{tabular}

Supplemental Table 3. Working camera trap nights of all cameras deployed by silviculture understory treatments in Silvicultural Experiment to Enhance Diversity (NHSEED) plots located in Baraga county, Michigan.

\begin{tabular}{c|c}
\hline Habitat & Working Trap Nights \\
\hline Control & 868 \\
\hline Scarification & 1071 \\
\hline Artificial Tip-up & 1382 \\
\hline
\end{tabular}


Supplemental Table 4. The number of detections per species from a combined baited and unbaited camera trap study in the Silvicultural Experiment for Enhancing Diversity (NHSEED) plots located in Baraga county, Michigan from June 04, 2019 through October 24, 2019.

\begin{tabular}{|c|c|c|}
\hline Common Name & Scientific Name & Count of Species \\
\hline American Marten & Martes americana & 3 \\
\hline Black Bear & Ursus americanus & 8 \\
\hline Eastern Chipmunk & Tamias striatus & 64 \\
\hline Flying Squirrel & Pteromyini spp. & 2 \\
\hline Gray Squirrel & Sciurus carolinensis & 1 \\
\hline Gray Wolf & Canis lupus & 1 \\
\hline Human & Homo Sapiens & 354 \\
\hline Least Chipmunk & Neotamias minimus & 177 \\
\hline Racoon & Procyon lotor & 9 \\
\hline Red Squirrel & $\begin{array}{c}\text { Tamiasciurus } \\
\text { hudsonicus }\end{array}$ & 11 \\
\hline Snowshoe Hare & Lepus americanus & 1 \\
\hline Southern Red-Backed Vole & Myodes gapperi & 12 \\
\hline Turkey & Meleagris gallopavo & 2 \\
\hline Unidentified Animal & - & 43 \\
\hline Unidentified Chipmunk & - & 4 \\
\hline Unidentified Mouse & - & 27 \\
\hline $\begin{array}{l}\text { Unidentified Small } \\
\text { Mammal }\end{array}$ & - & 127 \\
\hline Unidentified Squirrel & - & 8 \\
\hline Warbler & Parulidae & 1 \\
\hline White-Tailed Deer & Odocoileus virginianus & 379 \\
\hline White-Throated Sparrow & Zonotrichia albicollis & 1 \\
\hline Grand Total & & 1235 \\
\hline
\end{tabular}




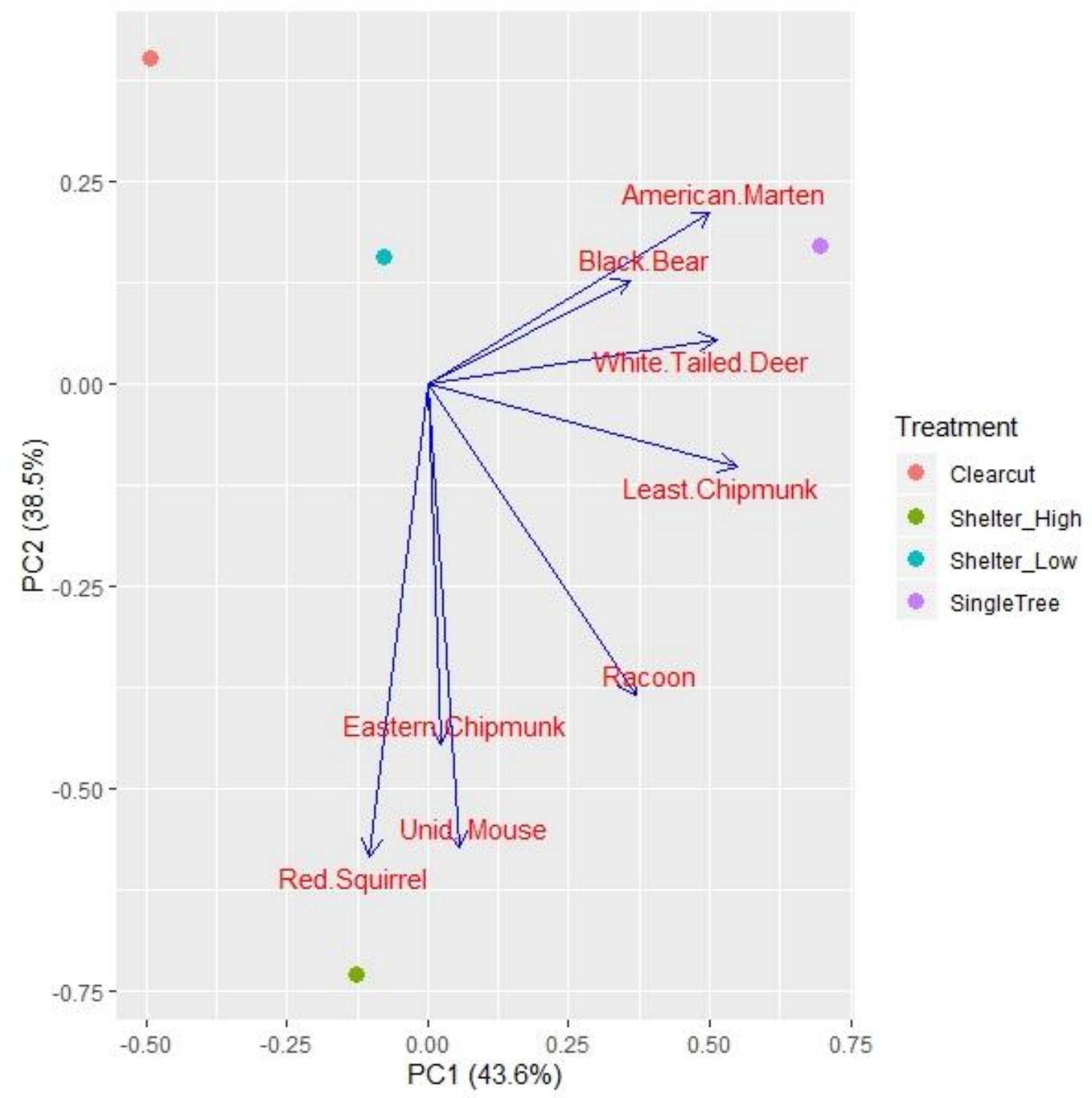

Supplemental Figure 1. Principal components analysis of the community composition of four different canopy treatments in the Silvicultural Experiment for Enhancing Diversity (NHSEED) plots located in Baraga county, Michigan from June 04, 2019 through October 24, 2019. The rare detections, or species with a single detection were removed to see if there was an influence of rare species detections. However, there was no effect from removing or including the rare detections. 


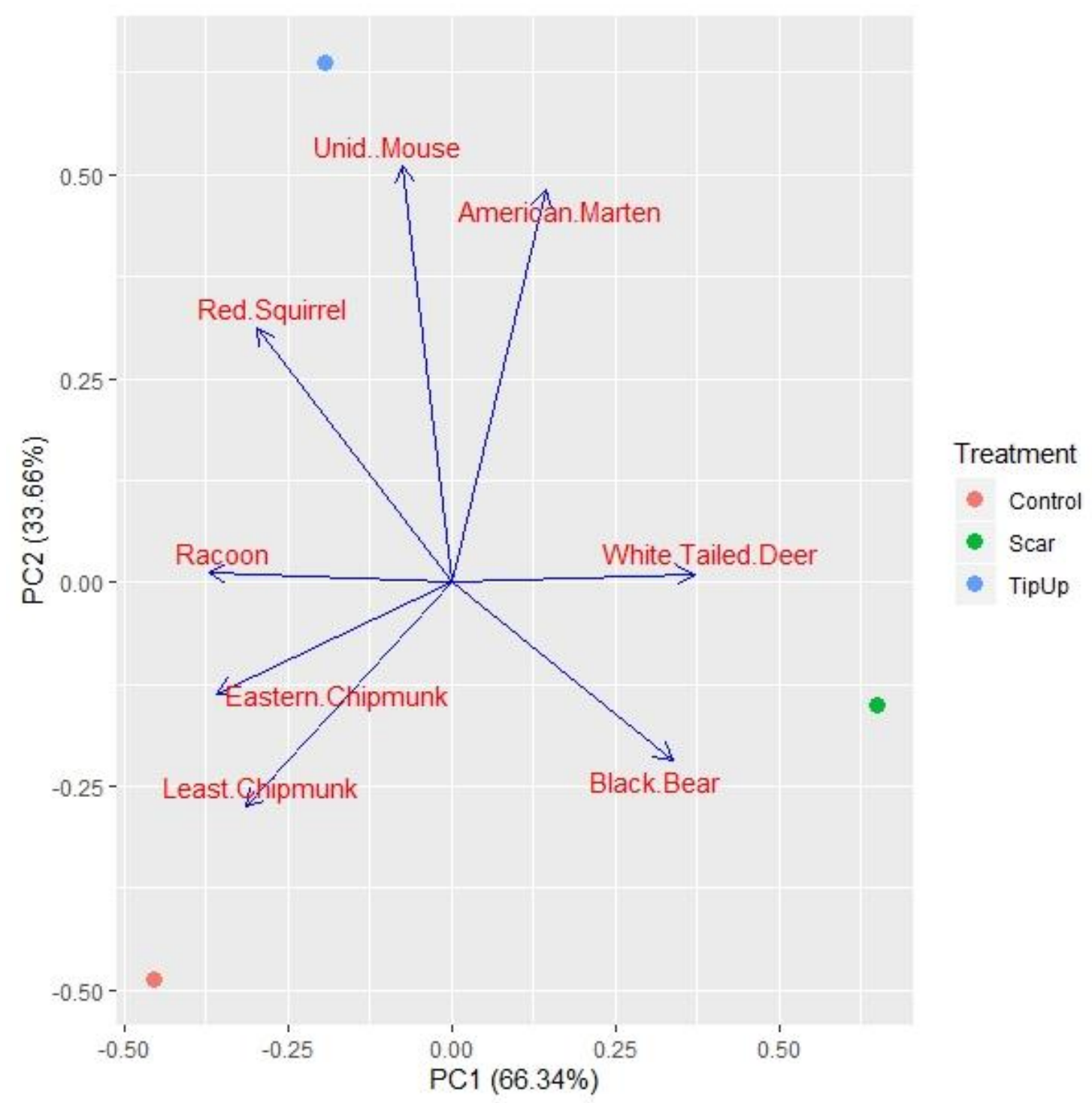

Supplemental Figure 2. Principal components analysis of the community composition of three different understory treatments in the Silvicultural Experiment for Enhancing Diversity (NHSEED) plots located in Baraga county, Michigan from June 04, 2019 through October 24, 2019. The rare detections, or species with a single detection were removed to see if there was an influence of rare species detections. However, there was no effect from removing or including the rare detections. 